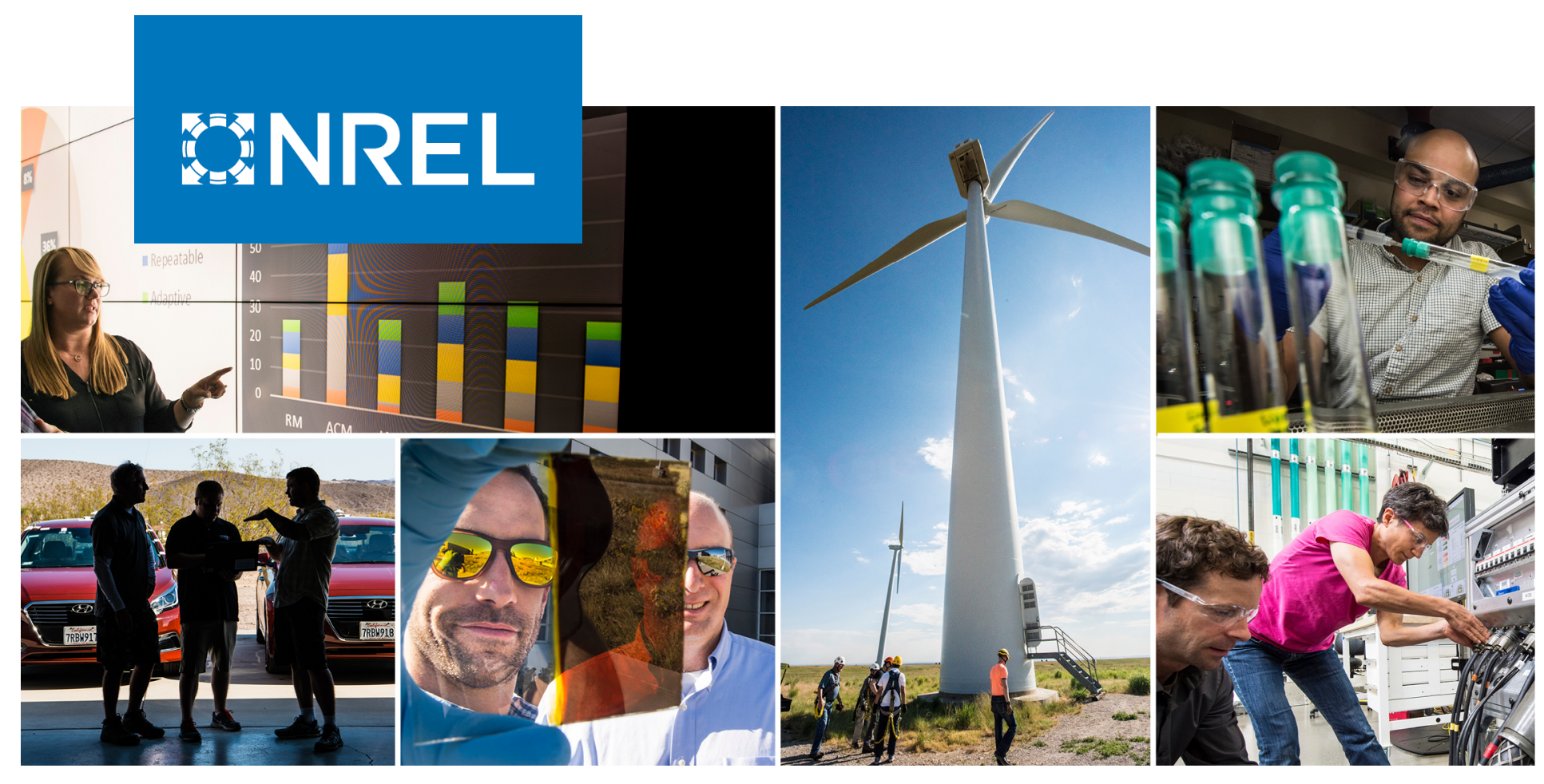

\title{
2019 Cost of Wind Energy Review
}

\author{
Tyler Stehly, Philipp Beiter, and Patrick Duffy
}

National Renewable Energy Laboratory

NREL is a national laboratory of the U.S. Department of Energy

Office of Energy Efficiency \& Renewable Energy

Operated by the Alliance for Sustainable Energy, LLC

This report is available at no cost from the National Renewable Energy Laboratory (NREL) at www.nrel.gov/publications.

\section{Technical Report}

NREL/TP-5000-78471

December 2020 


\title{
GHREL
}

\section{Cost of Wind Energy Review}

\author{
Tyler Stehly, Philipp Beiter, and Patrick Duffy
}

National Renewable Energy Laboratory

\section{Suggested Citation}

Stehly, Tyler, Philipp Beiter and Patrick Duffy. 2020. 2019 Cost of Wind Energy Review.

Golden, CO: National Renewable Energy Laboratory. NREL/TP-5000-78471.

https://www.nrel.gov/docs/fy210sti/78471.pdf.

NREL is a national laboratory of the U.S. Department of Energy Office of Energy Efficiency \& Renewable Energy Operated by the Alliance for Sustainable Energy, LLC

This report is available at no cost from the National Renewable Energy Laboratory (NREL) at www.nrel.gov/publications.

Contract No. DE-AC36-08GO28308
Technical Report

NREL/TP-5000-78471

December 2020

National Renewable Energy Laboratory 15013 Denver West Parkway Golden, CO 80401

303-275-3000 • www.nrel.gov 


\section{NOTICE}

This work was authored by the National Renewable Energy Laboratory, operated by Alliance for Sustainable Energy, LLC, for the U.S. Department of Energy (DOE) under Contract No. DE-AC36-08GO28308. Funding provided by the U.S. Department of Energy Office of Energy Efficiency and Renewable Energy Wind Energy Technologies Office. The views expressed herein do not necessarily represent the views of the DOE or the U.S. Government.

This report is available at no cost from the National Renewable Energy Laboratory (NREL) at www.nrel.gov/publications.

U.S. Department of Energy (DOE) reports produced after 1991 and a growing number of pre-1991 documents are available free via www.OSTI.gov.

Cover Photos by Dennis Schroeder: (clockwise, left to right) NREL 51934, NREL 45897, NREL 42160, NREL 45891, NREL 48097, NREL 46526.

NREL prints on paper that contains recycled content. 


\section{Acknowledgments}

The authors would like to thank Patrick Gilman (U.S. Department of Energy Office of Energy Efficiency and Renewable Energy Wind Energy Technologies Office [WETO]) for supporting this research. Thanks also to Daniel Beals of Allegheny Science and Technology (contractor to WETO), Gage Reber (WETO fellow), Alice Orrell (Pacific Northwest National Laboratory), and Bret Barker (contractor to WETO) for reviewing prior versions of this manuscript. Thank you to Ryan Wiser and Mark Bolinger (Lawrence Berkeley National Laboratory) and Alice Orrell (Pacific Northwest National Laboratory) for their analysis of wind project market data that informed this analysis and also to Travis Williams, Nick Grue, and Anthony Lopez (National Renewable Energy Laboratory) for their work in developing the national wind supply curves. Thanks also to Eric Lantz (National Renewable Energy Laboratory) for his technical guidance, contributions, and review of prior versions of this manuscript. Any remaining errors or omissions are the sole responsibility of the authors. 


\section{List of Acronyms}

$\begin{array}{ll}\text { AEP } & \text { annual energy production } \\ \text { ATB } & \text { Annual Technology Baseline } \\ \text { BOS } & \text { balance of system } \\ \text { CapEx } & \text { capital expenditures } \\ \text { cRF } & \text { capital recovery factor } \\ \text { CSM } & \text { Cost and Scaling Model } \\ \text { DOE } & \text { U.S. Department of Energy } \\ \text { FCR } & \text { fixed charge rate } \\ \text { GPRA } & \text { Government Performance and Results Act } \\ \text { GW } & \text { gigawatt } \\ \text { kW } & \text { kilowatt } \\ \text { LandBOSSE } & \text { Land-based Balance of System Systems } \\ & \text { Engineering } \\ \text { LCOE } & \text { levelized cost of energy } \\ \text { m } & \text { meter } \\ \text { m/s } & \text { meters per second } \\ \text { MACRS } & \text { Modified Accelerated Cost Recovery System } \\ \text { MW } & \text { megawatt } \\ \text { MWh } & \text { megawatt-hour } \\ \text { NREL } & \text { National Renewable Energy Laboratory } \\ \text { O\&M } & \text { operation and maintenance } \\ \text { OpEx } & \text { operational expenditures } \\ \text { ORCA } & \text { Offshore Wind Regional Cost Analyzer } \\ \text { PTC } & \text { production tax credit } \\ \text { USD } & \text { U.S. dollars } \\ \text { WACC } & \text { weighted-average cost of capital } \\ \text { WETO } & \text { Wind Energy Technologies Office } \\ \text { yr } & \text { year } \\ & \end{array}$




\section{Executive Summary}

This report uses representative utility-scale and distributed wind energy projects to estimate the levelized cost of energy (LCOE) for land-based and offshore wind power plants in the United States. Data and results detailed here are derived from 2019 commissioned plants and representative industry data as well as state-of-the-art modeling capabilities. Modeling is conducted to provide more granular detail on specific cost categories. This report represents the ninth annual installment and is intended to provide insight into current component-level costs as well as a basis for understanding variability in wind energy LCOE across the country.

The primary elements of this report include:

- Estimated LCOE for a representative, land-based wind project installed in a moderate wind resource in the United States in 2019

- Estimated LCOE for representative offshore fixed-bottom and floating projects in the North Atlantic and Pacific Coast regions of the United States

- Estimated LCOE for representative residential and commercial scale distributed wind projects installed in a moderate wind resource in the United States in 2019, a new addition to the report this year

- Sensitivity analyses showing the range of effects that basic LCOE variables could have on the cost of wind energy for land-based, offshore, and distributed wind systems

- Updated national supply curves for land-based and offshore wind based on geographically specific wind resource conditions paired with approximate wind turbine cost characteristics

- Updated fiscal year 2020 values for land-based and offshore wind used for Government Performance and Results Act (GPRA) reporting as well as illustrated progress toward established GPRA targets.

\section{Key Inputs and Results}

Throughout this report, the representative land-based, offshore, and distributed wind project types are referred to as "reference projects." Table ES1, Table ES2, Table ES3, Table ES4, and Table ES5 summarize the basic LCOE inputs and outputs for the reference land-based, fixedbottom, and floating offshore wind and residential and commercial distributed wind projects. The LCOE inputs include project capital expenditures (CapEx), operational expenditures (OpEx), project financing (characterized by a fixed charge rate [FCR]) and the respective turbine capacity factor associated with the net annual energy production estimates. Unless specifically stated, all data and analysis in the report are in 2019 U.S. dollars. 
Table ES1. Summary of the Land-Based Reference Project using 2.6-megawatt (MW) Wind Turbines

\begin{tabular}{|c|c|c|}
\hline & $\begin{array}{l}\text { 2.6-MW Land-Based } \\
\text { Wind Turbine } \\
\text { (\$/kilowatt [kW]) }\end{array}$ & $\begin{array}{l}\text { 2.6-MW Land-Based } \\
\text { Wind Turbine } \\
\text { (\$/megawatt- } \\
\text { hour [MWh]) }\end{array}$ \\
\hline Turbine capital cost & 991 & 17.4 \\
\hline Balance of system & 326 & 5.7 \\
\hline Financial costs & 120 & 2.1 \\
\hline CapEx & 1,436 & 25.2 \\
\hline OpEx; $\$ / k W / y r$ & 43 & 11.5 \\
\hline FCR (\%) [real] & \multicolumn{2}{|c|}{$6.5 \%$} \\
\hline Net annual energy production (MWh/MW/yr) & \multicolumn{2}{|c|}{3,734} \\
\hline Net capacity factor $(\%)$ & \multicolumn{2}{|c|}{$42.6 \%$} \\
\hline TOTAL LCOE (\$/MWh) & \multicolumn{2}{|c|}{37} \\
\hline
\end{tabular}

Table ES2. Summary of the Fixed-Bottom Reference Project using 6.1-MW Wind Turbines

\begin{tabular}{|c|c|c|}
\hline & $\begin{array}{c}\text { 6.1-MW Offshore Wind } \\
\text { Turbine }\end{array}$ & $\begin{array}{c}\text { 6.1-MW Offshore Wind } \\
\text { Turbine }\end{array}$ \\
\hline & $(\$ / k W)$ & (\$/MWh) \\
\hline Turbine capital cost & 1,301 & 17.7 \\
\hline Balance of system & 2,131 & 29.0 \\
\hline Financial costs & 645 & 8.8 \\
\hline CapEx & 4,077 & 55.6 \\
\hline OpEx (\$/kW/yr) & 124 & 29.0 \\
\hline FCR (real) [\%] & \multicolumn{2}{|c|}{$5.8 \%$} \\
\hline Net annual energy production (MWh/MW/yr) & \multicolumn{2}{|c|}{4,270} \\
\hline Net capacity factor (\%) & \multicolumn{2}{|c|}{$48.7 \%$} \\
\hline Total LCOE (\$/MWh) & \multicolumn{2}{|c|}{85} \\
\hline
\end{tabular}


Table ES3. Summary of the Floating Offshore Reference Project using 6.1-MW Turbines

\begin{tabular}{|c|c|c|}
\hline & $\begin{array}{l}\text { 6.1-MW Floating } \\
\text { Offshore Wind Turbine } \\
\qquad(\$ / k W)\end{array}$ & $\begin{array}{l}\text { 6.1-MW Floating } \\
\text { Offshore Wind Turbine } \\
\text { (\$/MWh) }\end{array}$ \\
\hline Turbine capital cost & 1,301 & 22.7 \\
\hline Balance of system & 3,237 & 56.6 \\
\hline Financial costs & 790 & 13.8 \\
\hline CapEx & 5,328 & 93.1 \\
\hline OpEx (\$/kW/yr) & 130 & 39.2 \\
\hline FCR (real) [\%] & \multicolumn{2}{|c|}{$5.8 \%$} \\
\hline Net annual energy production (MWh/MW/yr) & \multicolumn{2}{|c|}{3,328} \\
\hline Net capacity factor (\%) & \multicolumn{2}{|c|}{$38.0 \%$} \\
\hline Total LCOE (\$/MWh) & \multicolumn{2}{|c|}{132} \\
\hline
\end{tabular}

Note: GPRA values are not reported for floating offshore wind technology.

Table ES4. Summary of the Residential Distributed Wind Reference Project using a 20-kW Wind Turbine

\begin{tabular}{|c|c|c|}
\hline & $\begin{array}{c}\text { 20-kW Residential } \\
\text { Wind Turbine } \\
(\$ / k W)\end{array}$ & $\begin{array}{c}\text { 20-kW Residential } \\
\text { Wind Turbine } \\
\text { (\$/MWh) }\end{array}$ \\
\hline Turbine CapEx & 2,575 & 65.9 \\
\hline Balance-of-system CapEx & 3,100 & 79.4 \\
\hline Total CapEx & 5,675 & 145.3 \\
\hline OpEx (\$/kW/yr) & 35 & 13.6 \\
\hline FCR (real) [\%] & \multicolumn{2}{|c|}{$6.6 \%$} \\
\hline Net annual energy production (kWh/kW/yr) & \multicolumn{2}{|c|}{2,580} \\
\hline Net capacity factor (\%) & \multicolumn{2}{|c|}{$29.5 \%$} \\
\hline TOTAL LCOE (\$/MWh) & \multicolumn{2}{|c|}{159} \\
\hline
\end{tabular}


Table ES5. Summary of the Commercial Distributed Wind Reference Project using a 100-kW Wind Turbine

\begin{tabular}{|c|c|c|}
\hline & $\begin{array}{c}\text { 100-kW Commercial } \\
\text { Wind Turbine } \\
(\$ / k W)\end{array}$ & $\begin{array}{c}\text { 100-kW Commercial } \\
\text { Wind Turbine } \\
\text { (\$/MWh) }\end{array}$ \\
\hline Turbine CapEx & 2,530 & 53.7 \\
\hline Balance-of-system CapEx & 1,770 & 37.6 \\
\hline Total CapEx & 4,300 & 91.2 \\
\hline OpEx (\$/kW/yr) & 35 & 12.3 \\
\hline FCR (real) [\%] & \multicolumn{2}{|c|}{$6.0 \%$} \\
\hline Net annual energy production (kWh/kW/yr) & \multicolumn{2}{|c|}{2,846} \\
\hline Net capacity factor (\%) & \multicolumn{2}{|c|}{$32.5 \%$} \\
\hline TOTAL LCOE (\$/MWh) & \multicolumn{2}{|c|}{104} \\
\hline
\end{tabular}

In this report, 2019 installed land-based wind project data and costs are primarily obtained from Wiser and Bolinger (2020). These data are supplemented with outputs from NREL's cost models for wind turbine and balance-of-system detail. The offshore reference project data are estimated from installed 2019 global offshore projects as well as data collected from U.S.-proposed projects. The assumed wind resource regime and geospatial power plant characteristics (e.g., water depth and distance from shore) for the offshore reference plants are comparable to sites on the U.S. North Atlantic and Pacific Coast and are detailed in Appendix C. The residential and commercial distributed wind reference projects are informed by 2019 market data from Orrell et. al. (2020) and values produced from NREL's Balance-of-System Cost Model for Land-Based Wind (Eberle et al. 2019). The details for land-based, offshore, and distributed wind representative sites are reported in Appendix E.

The four major component LCOE categories-turbine CapEx, balance-of-system CapEx, finance CapEx, and OpEx - and many subcategories are represented in Figure ES1, Figure ES2, Figure ES3, and Figure ES4. These figures include wind turbine (e.g., wind turbine components), balance of system (e.g., development, electrical infrastructure, assembly, and installation), and financial costs (e.g., insurance and construction financing). The majority of the land-based reference project LCOE (47.3\%) is in the turbine itself, whereas the balance of system is the major contributor for the fixed-bottom and floating offshore reference projects, making up $34.3 \%$ and $42.8 \%$, respectively. The LCOE categories for the representative distributed wind projects only consider the turbine, balance of system, and operation and maintenance (O\&M) costs because there is limited empirical data on more detailed system cost breakdown for distributed wind projects. For the representative residential distributed wind project, the balance-of-system cost comprises a majority of the $\mathrm{LCOE}$ at $50 \%$, whereas the commercial distributed wind project cost is accounted for by the turbine itself, contributing $51.8 \%$ of the LCOE. 


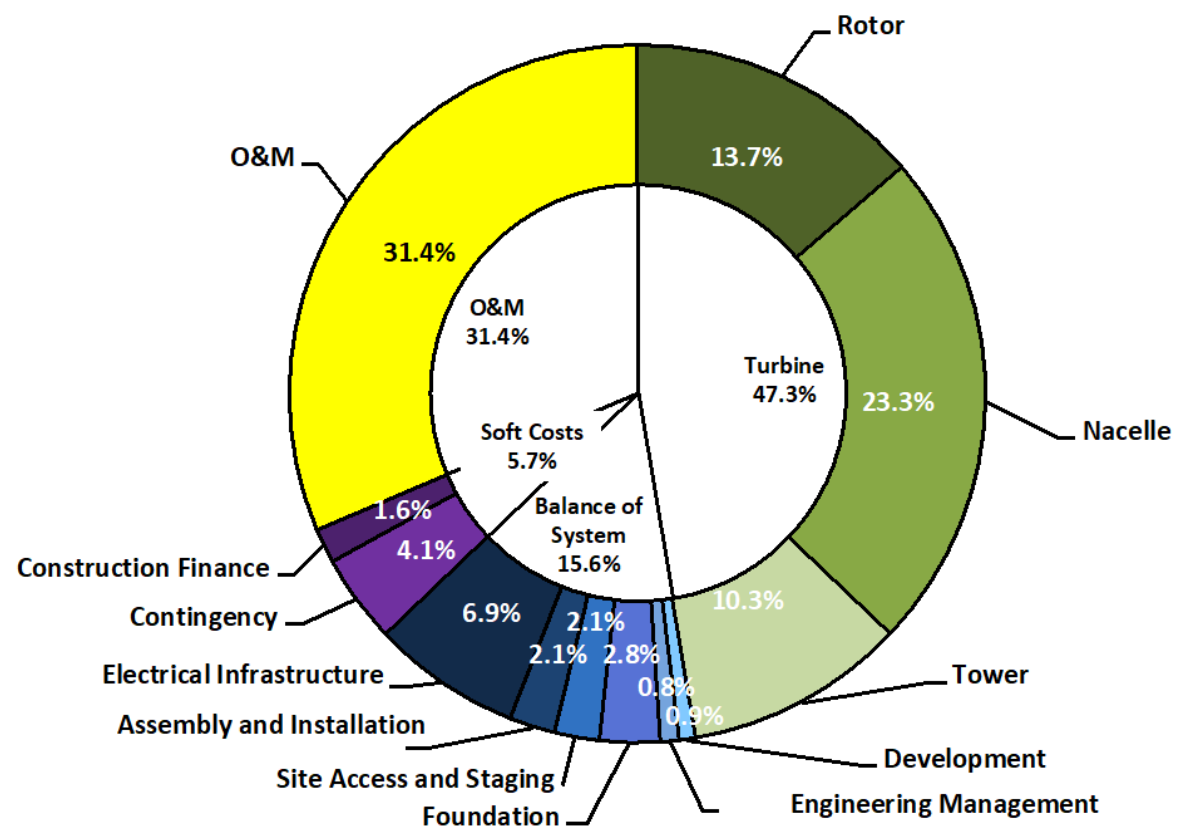

Figure ES1. Component-level LCOE contribution for the 2019 land-based wind reference project operating for 25 years

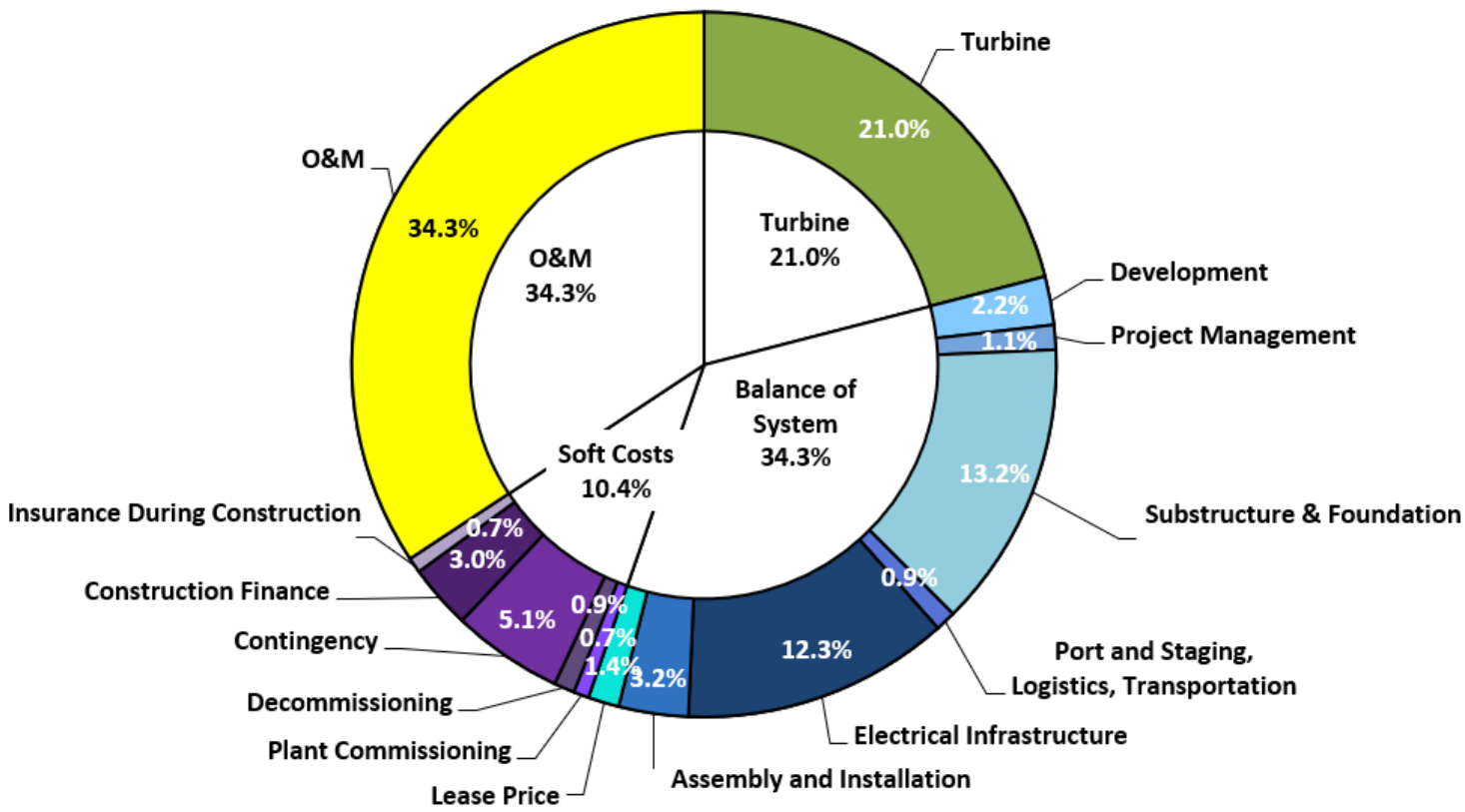

Figure ES2. Component-level LCOE contribution for the 2019 fixed-bottom offshore wind reference project operating for 25 years 


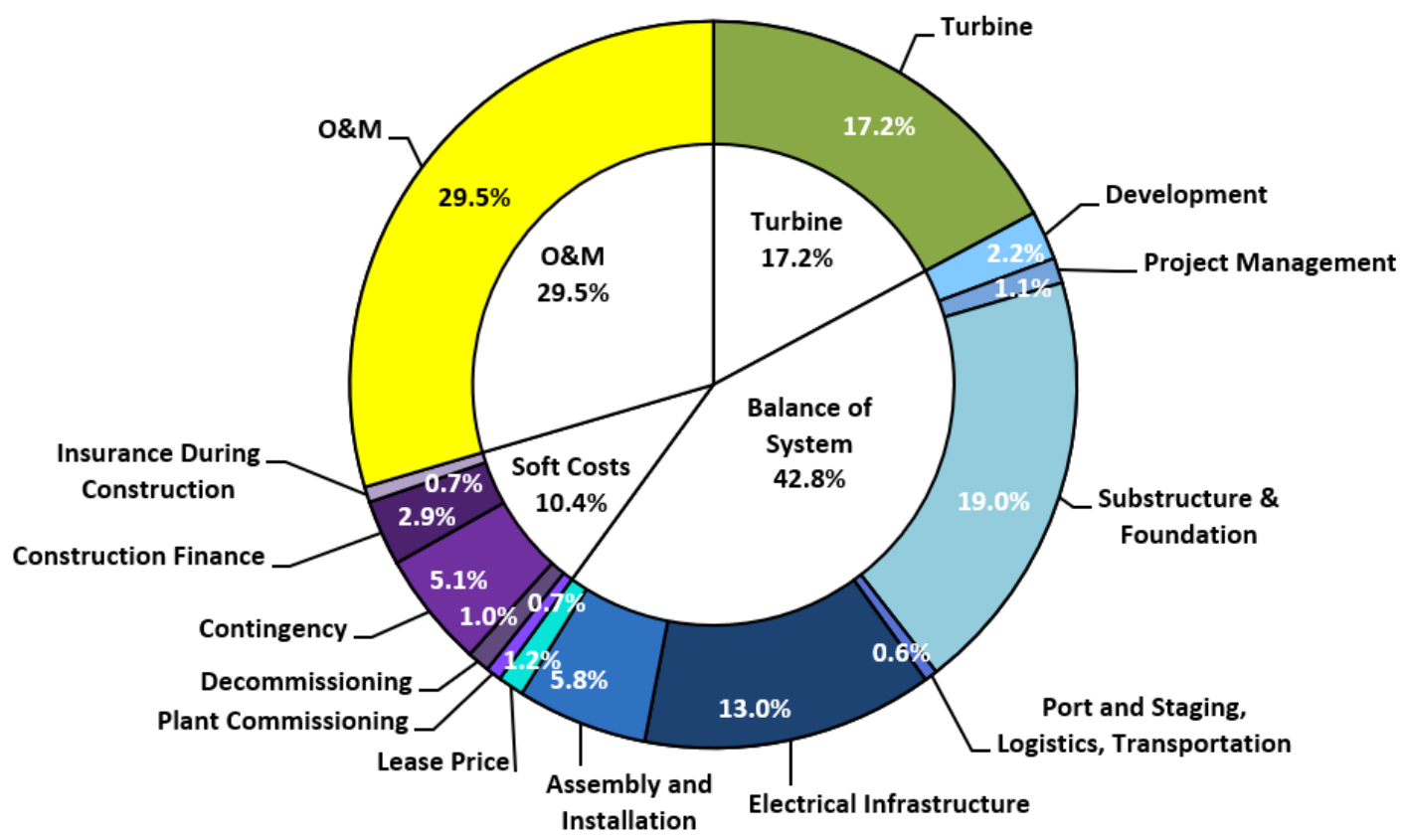

Figure ES3. Component-level LCOE contribution for the 2019 floating offshore wind reference project operating for 25 years
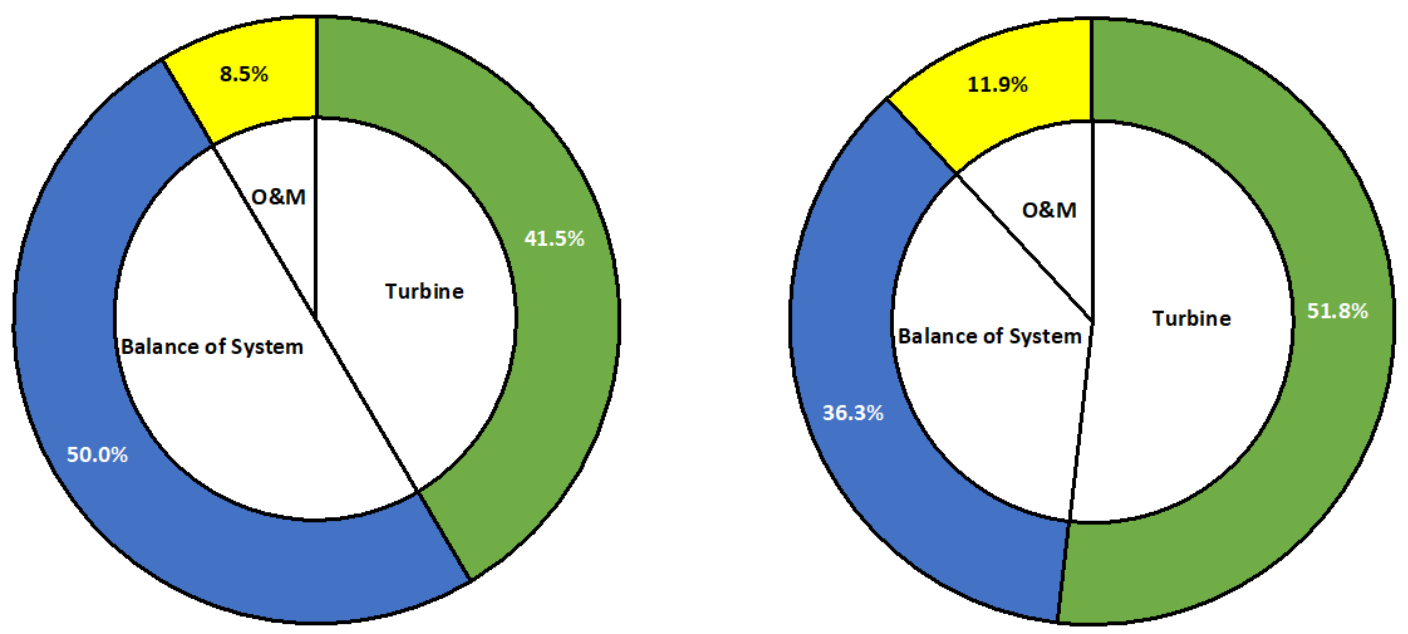

Figure ES4. Component-level LCOE contribution for the 2019 residential (left) and commercial (right) distributed wind reference projects operating for 25 years

Note: Empirical data and cost model representation for residential and commercial distributed wind projects are limited, hence, detailed component-level LCOE contributions are not presented in this report.

Figure ES5, Figure ES6, Figure ES7, Figure ES8, and Figure ES9 illustrate the LCOE associated with the land-based and offshore reference power plants and provide a range of independent, 
single-variable sensitivities showing how these variables affect cost and performance. More specifically, these figures show the effect that CapEx, OpEx, net capacity factor, nominal discount rate, and project design life ${ }^{1}$ have on the LCOE for land-based, offshore, and distributed wind projects. Reference project values of $\$ 37 / \mathrm{MWh}$ for land-based wind, $\$ 85 / \mathrm{MWh}$ for fixedbottom offshore wind, $\$ 132 / \mathrm{MWh}$ for floating offshore wind, $\$ 159 / \mathrm{MWh}$ for residential distributed wind, and $\$ 104 / \mathrm{MWh}$ for commercial distributed wind rely on inputs summarized in Table ES1 through Table ES5 and are identified by the vertical white line in these figures. The figures also show sensitivity ranges pulled from representative industry data contained in the "Wind Energy Technology Data Update: 2020 Edition" (Wiser and Bolinger 2020) for the LCOE inputs and the resulting calculated impacts on LCOE for land-based wind. The sensitivity ranges for fixed-bottom and floating offshore are informed by the "2019 Offshore Wind Technologies Update" (Musial et. al. 2020) and NREL's offshore wind database. The sensitivity ranges for residential and commercial distributed wind are pulled from representative industry data and analysis contained in the "2019 Distributed Wind Data Summary" (Orrell et al. 2020). The ranges for land-based and offshore wind LCOE inputs vary significantly (note the different axes in these figures). More detailed descriptions of the ranges and assumptions are included in Section 4.7 (land-based wind), Section 5.7 (offshore wind), and Section 6.7 (distributed wind).

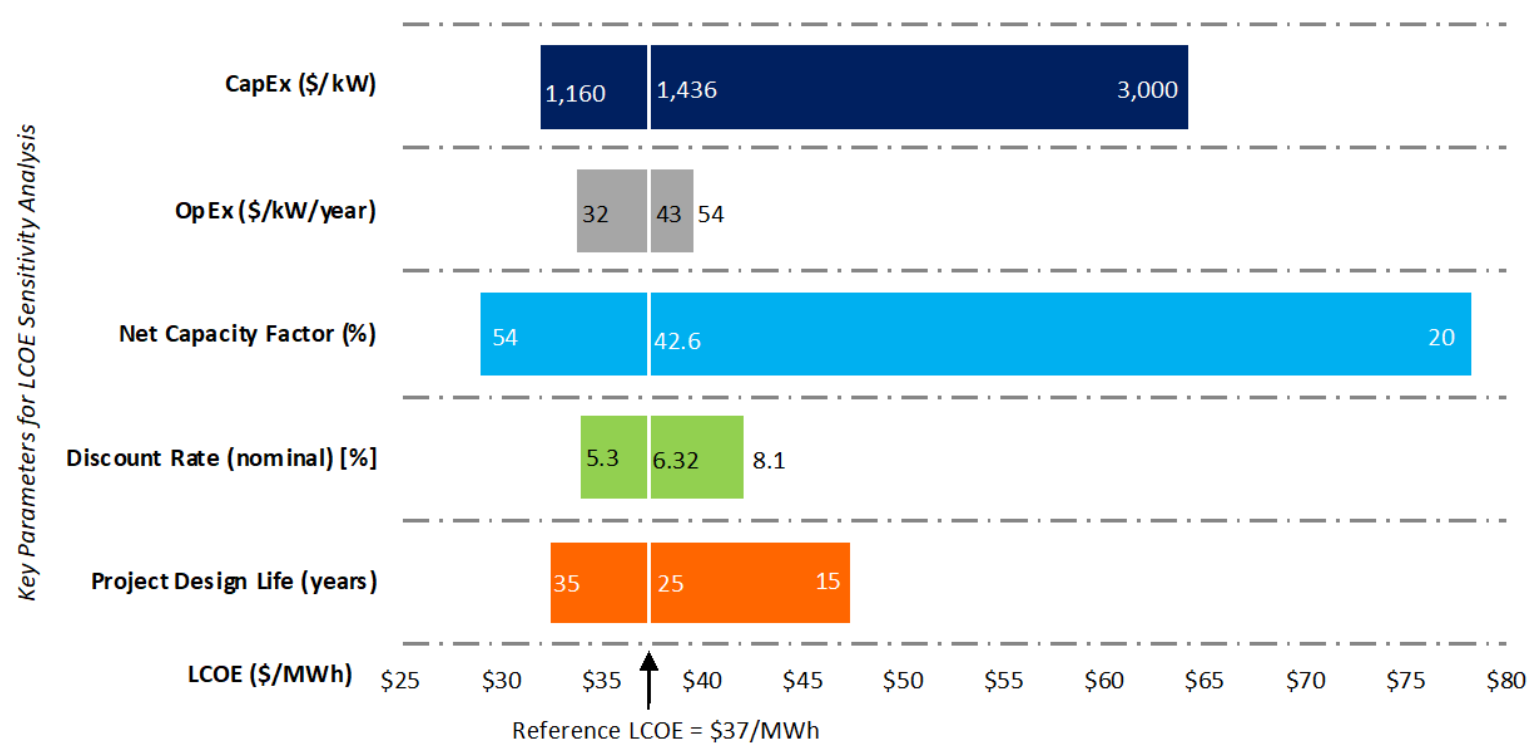

Figure ES5. Land-based wind power plant assumptions and ranges for key LCOE input parameters

Note: The reference LCOE represents the estimated LCOE for the NREL reference project. Changes in LCOE for a single variable can be understood by moving to the left or right along a specific variable. Values on the $\mathrm{x}$-axis indicate how the LCOE will change as a given variable is altered, assuming that all others are constant. For example, as capacity factor decreases toward $20 \%$, the LCOE shown on the $\mathrm{x}$-axis will increase accordingly to approximately $\$ 78 / \mathrm{MWh}$. Or, as the operational life for the reference project moves toward 35 years, the period in which a project achieves the requisite cash flow it needs to recover its initial CapEx and meet investors' internal rate of return threshold is assumed to be 35 years; therefore, the resulting LCOE decreases to nearly $\$ 32 / \mathrm{MWh}$.

\footnotetext{
${ }^{1}$ Project design life refers to the time in which the wind power plant is expected to operate (not referring to the turbine's design life for engineering or certification purposes).
} 


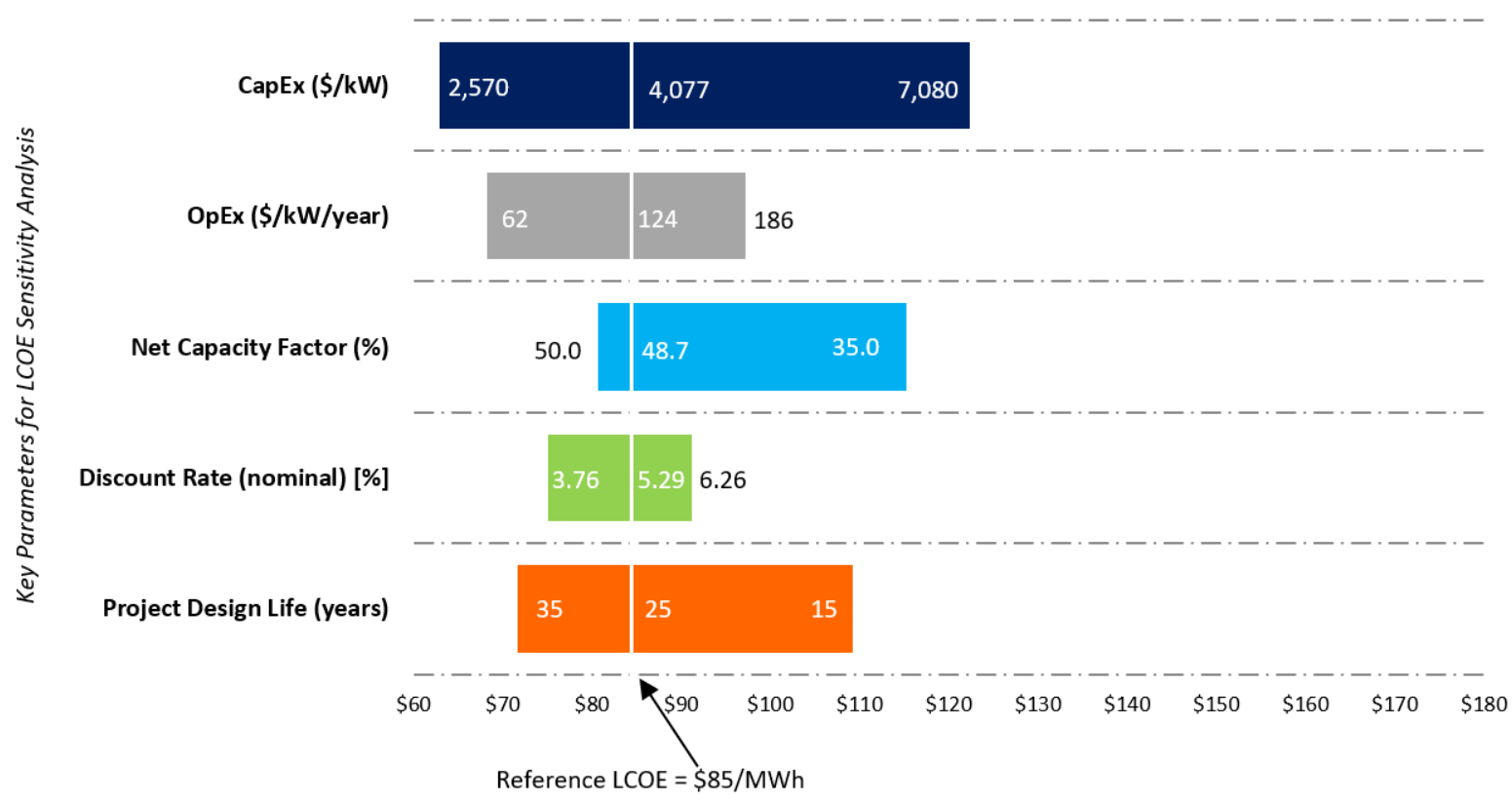

Figure ES6. Fixed-bottom offshore wind power plant assumption and ranges for key LCOE input parameters

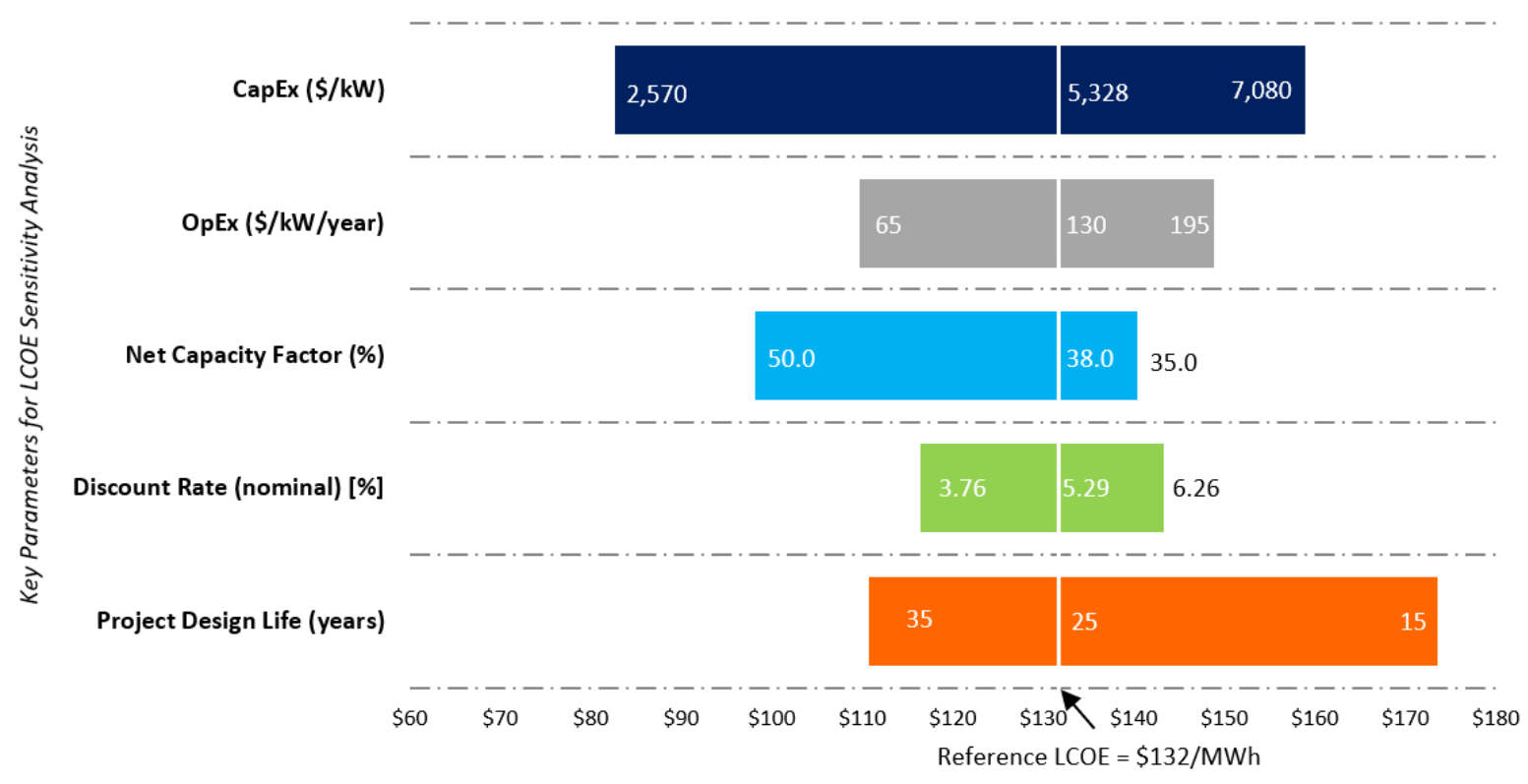

Figure ES7. Floating offshore wind power plant assumptions and ranges for key LCOE input parameters 


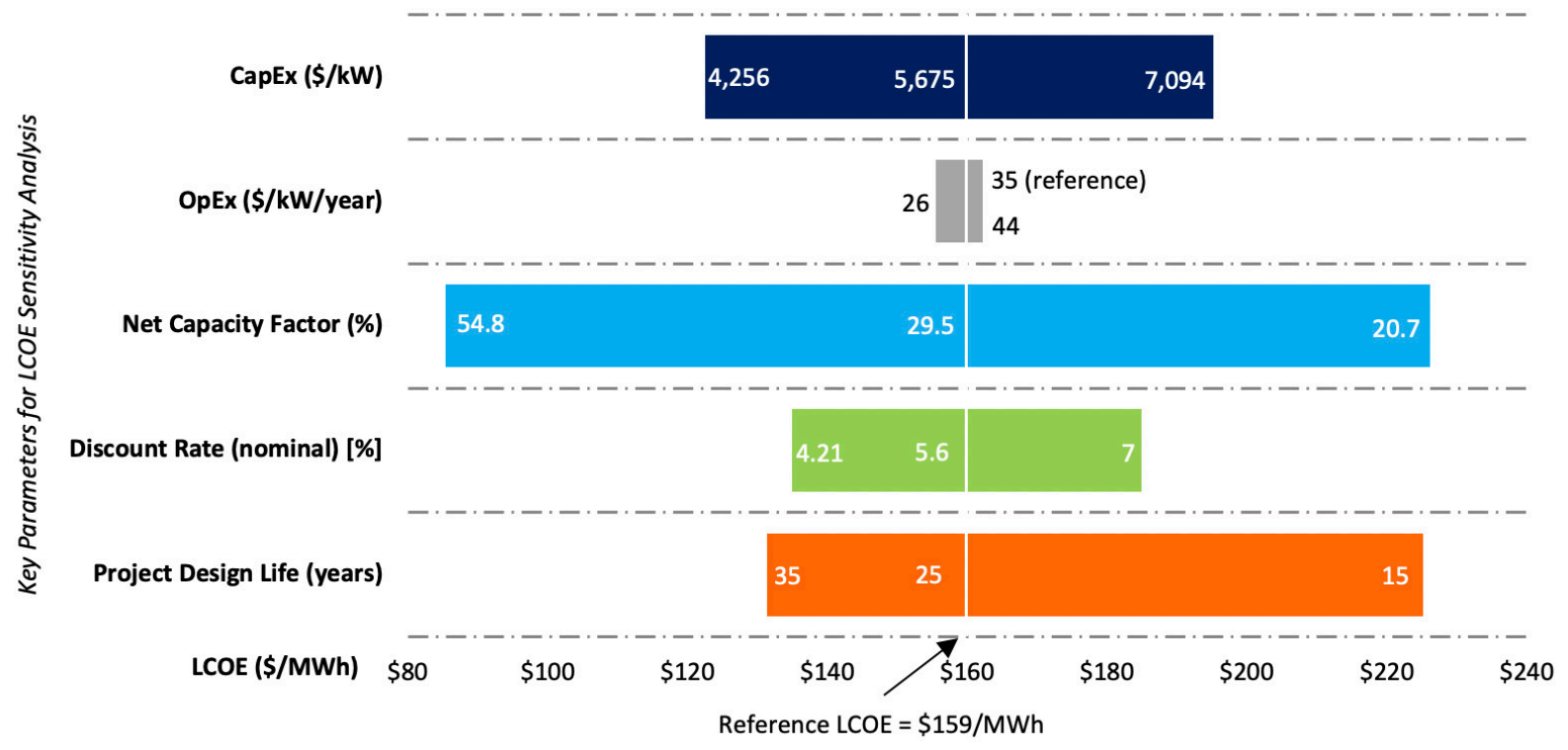

Figure ES8. Residential distributed wind system assumptions and ranges for key LCOE input parameters

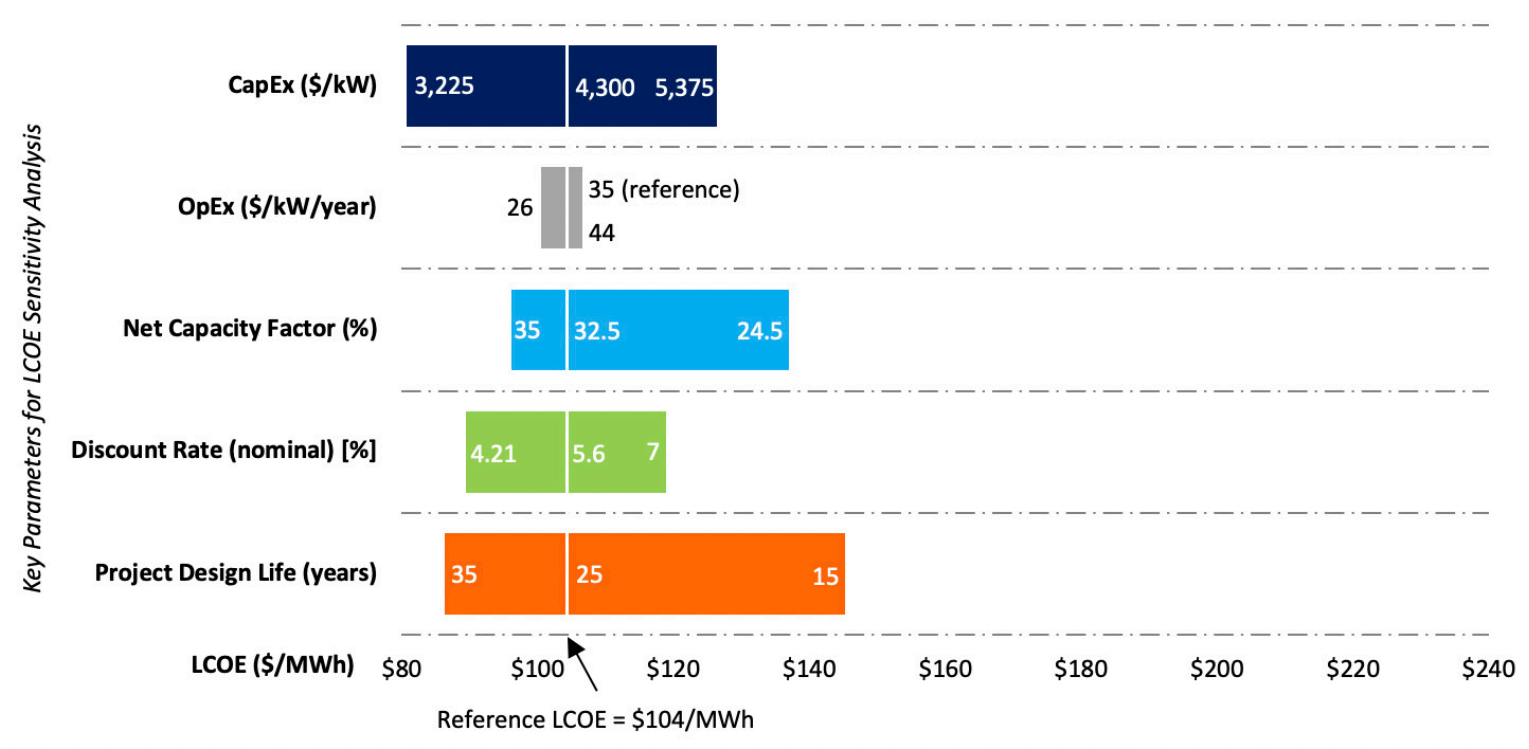

Figure ES9. Commercial distributed wind system assumptions and ranges for key LCOE input parameters

From the analysis detailed in this report, we derived the following key conclusions:

- Land-based wind power plant LCOE estimates continue to show a downward trend from the "2010 Cost of Wind Energy Review" (Tegen et al. 2012) to the 2019 review. The reference project LCOE for land-based installations was observed to be $\$ 37 / \mathrm{MWh},{ }^{2}$ with

\footnotetext{
${ }^{2}$ As the production tax credit ramps down and expires in 2020, it is likely that wind project weighted-average cost of capital or discount rate will be reduced, as leverage increases and tax equity is replaced with cheaper debt.
} 
a range of land-based estimates from the single-variable sensitivity analysis covering \$29-\$78/MWh. ${ }^{3}$

- Offshore wind power plant LCOE estimates continue to decrease. The fixed-bottom reference project offshore estimate is $\$ 85 / \mathrm{MWh}$, and the floating substructure reference project estimate is $\$ 132 / \mathrm{MWh}$. These two reference projects give a single-variable sensitivity range of $\$ 63-\$ 174 / \mathrm{MWh}$. This range is primarily caused by the large variation in CapEx $(\$ 2,470-\$ 7,080 / \mathrm{kW})$, which is partially a function of water depth and distance from shore reported by project developers. More recent European and U.S. auction bids suggest that costs for offshore wind could fall further in the coming years. ${ }^{4}$

- The report now includes LCOE estimates for reference residential and commercial distributed wind systems using a blended approach of empirical data and cost models. The residential reference system LCOE was estimated at $\$ 159 / \mathrm{MWh}$, with a range of values from the single-variable sensitivity analysis of $\$ 85-226 / \mathrm{MWh}$. The commercial reference system LCOE was estimated at \$104/MWh, with a range of values from \$81\$145/MWh from the single-variable sensitivity analysis.

\footnotetext{
${ }^{3}$ LCOE estimates reflect a cost to a wind power plant developer and are not directly comparable with power purchase agreements that reflect the sale of electricity.

${ }^{4}$ Additional information on the recent European and U.S. auction bids can be found in the "2018 Offshore Wind Technologies Market Report” (Musial et al. 2019).
} 


\section{Table of Contents}

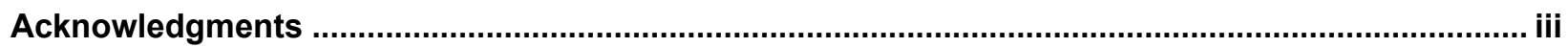

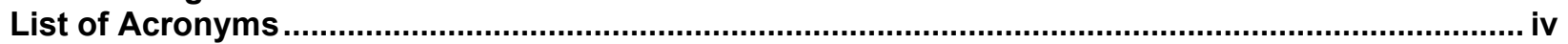

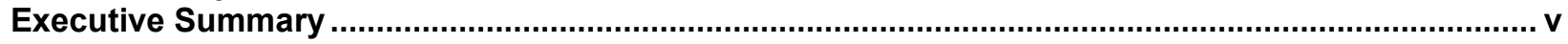

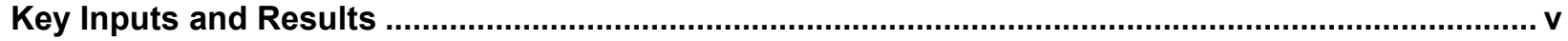

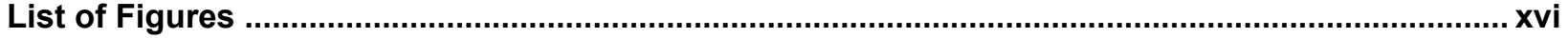

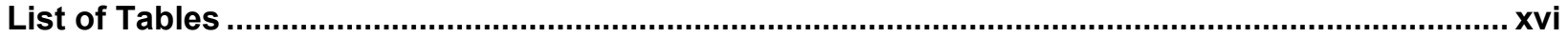

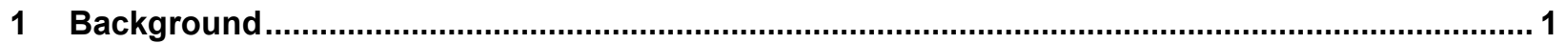

2 U.S. Department of Energy Goals and Reporting Requirements ............................................. 3

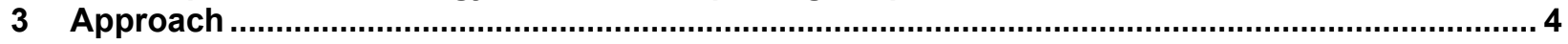

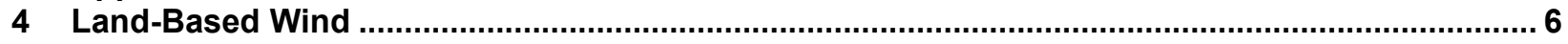

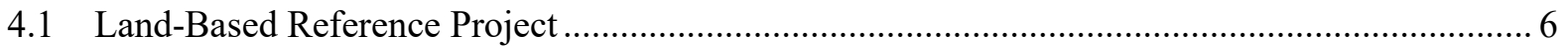

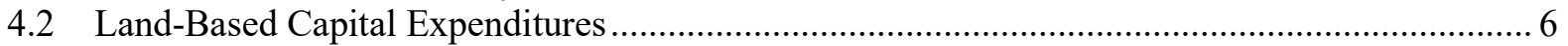

4.3 Land-Based Technology Characteristics and Annual Energy Production .................................. 9

4.4 Land-Based Operation and Maintenance Expenditures ........................................................ 11

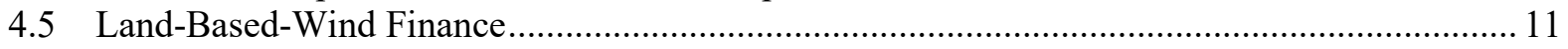

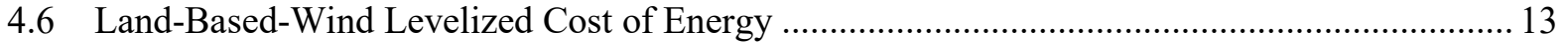

4.7 Land-Based-Wind Levelized Cost of Energy Sensitivities ...................................................... 15

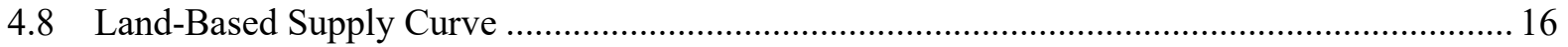

4.9 Land-Based-Wind Discussion of Results in Context of DOE Goals ..................................... 17

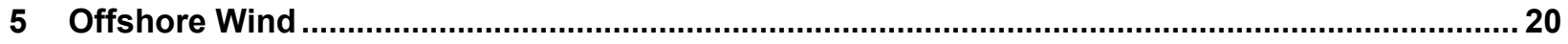

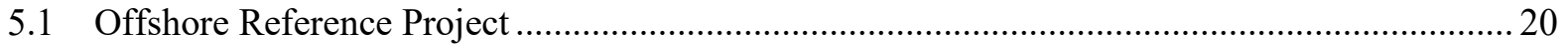

5.2 Offshore Capital Expenditures ......................................................................................... 21

5.3 Offshore Technology Characteristics and Annual Energy Production ...................................... 24

5.4 Offshore Operation and Maintenance Expenditures ................................................................ 27

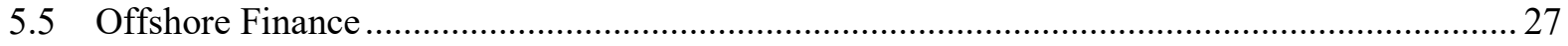

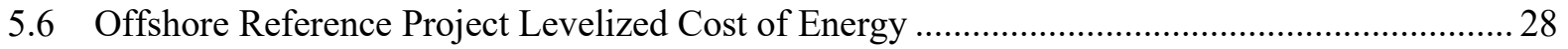

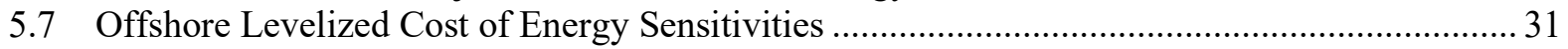

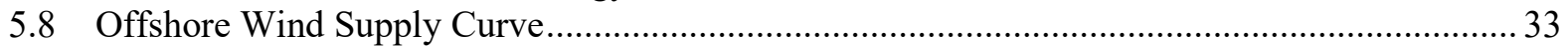

5.9 Offshore Discussion of Results in Context of DOE Goals...................................................... 34

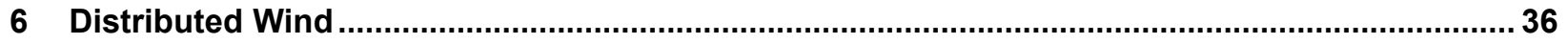

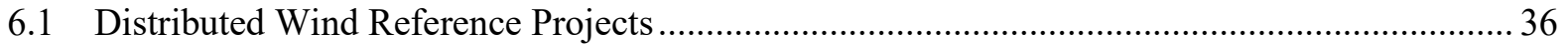

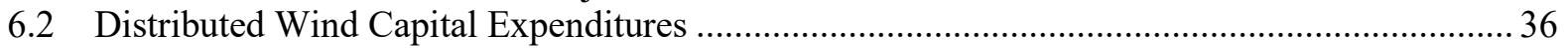

6.3 Distributed Wind Technology Characteristics and Annual Energy Production.......................... 37

6.4 Distributed Wind Operation and Maintenance Expenditures.................................................... 39

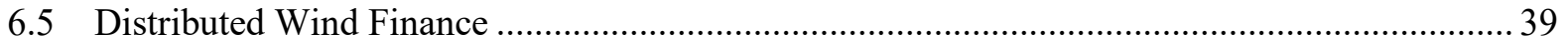

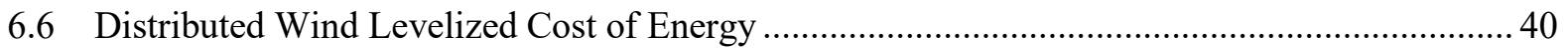

6.7 Distributed Wind Levelized Cost of Energy Sensitivities.................................................... 42

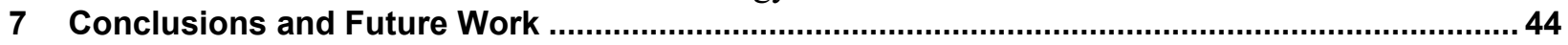

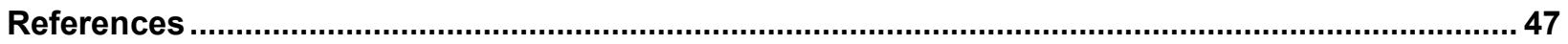

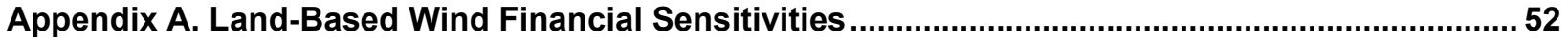

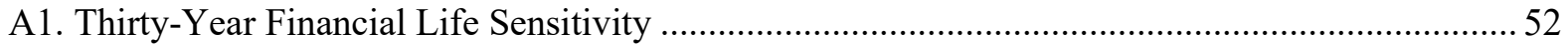

A2. Financial Sensitivity from the 2018 Cost of Wind Energy Review ........................................... 52

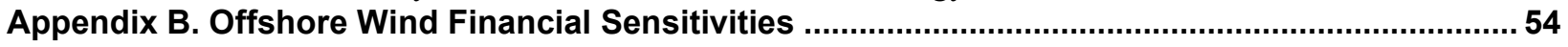

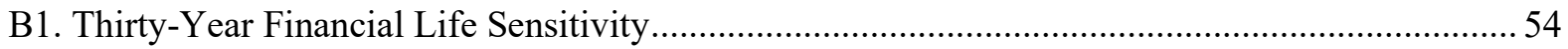

B2. Financing Sensitivity from 2018 Cost of Wind Energy Review ................................................5 54

Appendix C. Offshore Wind Reference Site Development ............................................................5 56

Appendix D. Offshore Wind Cost Model Updates ....................................................................... 58

Appendix E. Summary of Assumptions for 2019 Reference Projects ............................................. 59 


\section{List of Figures}

Figure ES1. Component-level LCOE contribution for the 2019 land-based wind reference project operating for 25 years

Figure ES2. Component-level LCOE contribution for the 2019 fixed-bottom offshore wind reference project operating for 25 years. ix

Figure ES3. Component-level LCOE contribution for the 2019 floating offshore wind reference project operating for 25 years

Figure ES4. Component-level LCOE contribution for the 2019 residential (left) and commercial (right) distributed wind reference projects operating for 25 years

Figure ES5. Land-based wind power plant assumptions and ranges for key LCOE input parameters

Figure ES6. Fixed-bottom offshore wind power plant assumption and ranges for key LCOE input

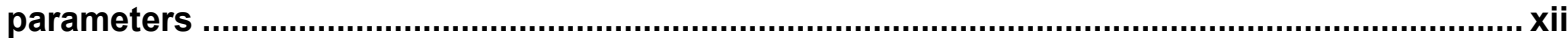

Figure ES7. Floating offshore wind power plant assumptions and ranges for key LCOE input parameters ............................................................................................................................. xii

Figure ES8. Residential distributed wind system assumptions and ranges for key LCOE input parameters

Figure ES9. Commercial distributed wind system assumptions and ranges for key LCOE input

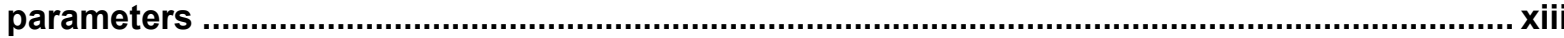

Figure 1. CapEx for the land-based reference wind power plant project..

Figure 2. Component-level LCOE contribution for the 2019 land-based-wind reference project operating for 25 years ........................................................................................................ 14

Figure 3. Component-level LCOE breakdown for the 2019 land-based-wind reference project ...... 15

Figure 4. Sensitivity of land-based-wind LCOE to key input parameters .......................................15

Figure 5. National land-based-wind resource supply curve with 2019 U.S. installed projects.......... 17

Figure 6. Pathway to LCOE reduction in 2030 by LCOE parameter ................................................ 18

Figure 7. Land-based wind GPRA cost trajectories for LCOE (in 2015 USD) ................................... 19

Figure 8. Capital expenditures for the fixed-bottom offshore wind reference project ..................... 22

Figure 9. Capital expenditures for the floating offshore wind reference project ............................. 23

Figure 10. Component-level LCOE contribution for the 2019 fixed-bottom offshore wind reference project operating for 25 years ............................................................................................... 29

Figure 11. Component-level cost breakdown for the 2019 fixed-bottom offshore wind reference project.

Figure 12. Component-level LCOE contribution for the 2019 floating offshore wind reference project operating for 25 years

Figure 13. Component-level cost breakdown for the 2019 floating offshore wind reference project

Figure 14. Sensitivity of fixed-bottom offshore wind LCOE to key input parameters

Figure 15. Sensitivity of floating offshore wind LCOE to key input parameters ...............................32

Figure 16. National fixed-bottom and floating offshore wind supply curve ....................................3. 34

Figure 17. Fixed-bottom wind GPRA cost trajectories for LCOE................................................. 35

Figure 18. Fixed-bottom cost reductions in GPRA cost trajectories for LCOE................................. 35

Figure 19. CapEx for the residential (left) and commercial (right) reference wind projects .............. 37

Figure 20. Component-level LCOE contribution for the 2019 residential (left) and commercial

(right) distributed wind reference projects operating for 25 years ............................................42

Figure 21. Sensitivity of residential distributed wind LCOE to key input parameters....................... 42

Figure 22. Sensitivity of commercial distributed wind LCOE to key input parameters.................... 43

\section{List of Tables}

Table ES1. Summary of the Land-Based Reference Project using 2.6-megawatt (MW) Wind

Turbines.

Table ES2. Summary of the Fixed-Bottom Reference Project using 6.1-MW Wind Turbines

Table ES3. Summary of the Floating Offshore Reference Project using 6.1-MW Turbines .............. vii

Table ES4. Summary of the Residential Distributed Wind Reference Project using a 20-kW Wind 
Turbine. vii Table ES5. Summary of the Commercial Distributed Wind Reference Project using a 100-kW Wind Turbine.. viii

Table 1. Land-Based Wind GPRA Baseline and Target LCOE ................................................... 3

Table 2. Offshore Fixed-Bottom Wind GPRA Baseline and Target LCOE............................................ 3

Table 3. Land-Based Reference Project Parameters........................................................................ 6

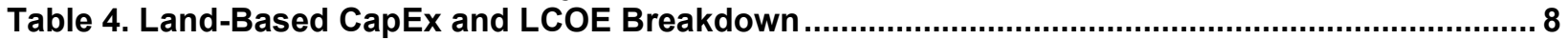

Table 5. Reference Land-Based Wind Turbine Parameters ............................................................ 9

Table 6. Reference Land-Based-Wind Resource Assumptions .................................................... 10

Table 7. Reference Land-Based-Wind Losses and Availability Assumptions................................... 10

Table 8. Reference Land-Based-Wind Power Plant AEP and Capacity Factor Summary .................. 10

Table 9. Land-Based-Wind Reference Project OpEx ......................................................................... 11

Table 10. Summary of Land-Based-Wind Reference Project Economic Evaluation Metrics ............. 13

Table 11. Summary of Inputs and Reference Project LCOE for 2019 Land-Based Installations ...... 14

Table 12. Offshore Reference Project Parameters (Fixed-Bottom and Floating Substructures) ..... 21

Table 13. Fixed-Bottom Offshore CapEx and LCOE Breakdown ................................................. 23

Table 14. Floating Offshore CapEx and LCOE Breakdown .......................................................... 24

Table 15. Reference Offshore Wind Turbine Parameter Input Assumptions................................... 25

Table 16. Reference Offshore Wind Resource Input Assumptions ............................................... 26

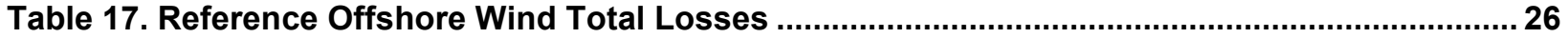

Table 18. Reference Offshore Wind Net Annual Energy Production ............................................... 27

Table 19. Offshore Wind Reference Project OpEx....................................................................... 27

Table 20. Summary of Offshore Reference Project Economic Evaluation Metrics ............................ 28

Table 21. Fixed-Bottom Offshore Wind LCOE and Reference Projects Cost Breakdown................. 29

Table 22. Floating Offshore Wind LCOE and Reference Projects Cost Breakdown ........................ 30

Table 23. Distributed Wind Reference Projects Parameters ............................................................... 36

Table 24. Distributed Wind CapEx and LCOE Breakdown........................................................... 37

Table 25. Reference Distributed Wind Turbine Parameters .......................................................... 38

Table 26. Reference Residential and Commercial Distributed Wind Resource Assumptions ......... 38

Table 27. Reference Residential and Commercial Distributed Wind Project Losses and Availability

Assumptions ...................................................................................................................... 38

Table 28. Reference Residential and Commercial Distributed Wind Projects AEP and Capacity

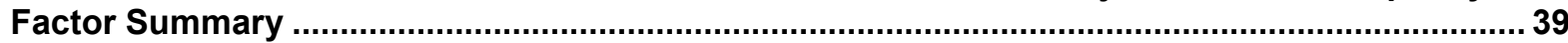

Table 29. Distributed Wind Reference Projects OpEx.................................................................... 39

Table 30. Summary of Distributed Wind Reference Projects Economic Evaluation Metrics ............ 40

Table 31. Summary of Inputs and Reference Project LCOE for 2019 Residential Distributed Wind 41

Table 32. Summary of Inputs and Reference Project LCOE for 2019 Commercial Distributed Wind

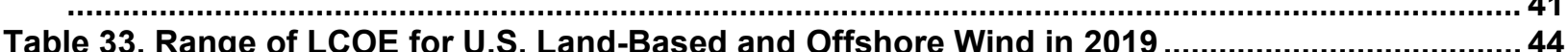

Table 34. Range of LCOE for Residential and Commercial Distributed Wind in 2019.......................44

Table A1. Summary of Land-Based Capital Recovery Factor, Fixed Charge Rate, and Levelized Cost of Energy for a 30-Year Useful Life.

Table A2. Summary of Land-Based Capital Recovery Factor and Levelized Cost of Energy for a $7.5 \%$ FCR

Table B1. Summary of Offshore Capital Recovery Factor, Fixed Charge Rate, and Levelized Cost of Energy for a 30 -Year Useful Life.

Table B2. Summary of Offshore Capital Recovery Factor, Fixed Charge Rate, and Levelized Cost of Energy Using the 2018 Cost of Wind Energy Review Assumptions (25-year Life) .................. 55

Table C1. Spatial Parameters for Regional Reference Sites .............................................................5 57

Table E1. Land-Based-Wind Reference Project Levelized Cost of Energy Assumptions ................. 59

Table E2. Fixed-Bottom Offshore Wind Reference Project Levelized Cost of Energy Assumptions

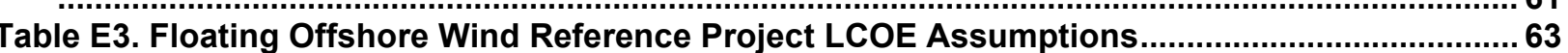

Table E4. Residential Distributed Wind Reference Project LCOE Assumptions ..............................65

Table E5. Commercial Distributed Wind Reference Project LCOE Assumptions ............................67 


\section{Background}

This report estimates the levelized cost of energy (LCOE) for land-based and offshore wind projects in the United States. LCOE is a metric used to assess the cost of electricity generation and the total power-plant-level impact from technology design changes and can be used to compare costs of all types of generation. The specific LCOE method applied in this analysis is described in "A Manual for the Economic Evaluation of Energy Efficiency and Renewable Energy Technologies" (Short et al. 1995).

This report provides an update to the "2018 Cost of Wind Energy Review" (Stehly et al. 2019) and a look at the 2019 wind industry LCOE, wind turbine costs, financing, and market conditions. More specifically, this 2019 report includes:

- Estimated LCOE for a representative, land-based wind project installed in a moderate wind resource (i.e., International Electrotechnical Commission [IEC] wind class IIb [IEC 2020]) in the United States in 2019

- Estimated LCOE for representative offshore (fixed-bottom and floating) projects using National Renewable Energy Laboratory (NREL) models and databases of globally installed projects. Representative sites on the U.S. North Atlantic Coast (fixed bottom) and Pacific Coast (floating) were assessed using current lease and call information, nominations data from the Bureau of Ocean Energy Management, and various geospatial data sets

- New for this year, LCOE estimates for representative residential and commercial distributed wind projects in the United States in 2019 to this year's report

- Sensitivity analyses showing the range of effects that basic LCOE variables could have on the cost of wind energy for land-based and offshore wind power plants

- Updates to the national supply curves for land-based and offshore wind based on geographically specific wind resource conditions paired with approximate wind turbine size characteristics

- Projected land-based and offshore wind cost trajectories from 2019 through 2030 used for U.S. Department of Energy (DOE) annual wind power LCOE reporting as required by the Government Performance and Results Act (GPRA).

This report addresses a number of assumptions and cost variables but does not include the full spectrum of drivers that affect wind energy prices. For example, it does not consider policy incentives (such as the production tax credit [PTC]), factors from underlying economic conditions (such as an economic recession), the cost of building long-haul interstate transmission, or potential grid integration costs. These important variables can have an impact by increasing or decreasing project costs or delaying projects. Nevertheless, their exclusion is consistent with past economic analyses conducted by NREL (Stehly et al. 2018), as LCOE is not traditionally defined as a measure of all societal costs and benefits associated with power generation resources.

The standard Annual Technology Baseline (ATB) LCOE equation (NREL's Annual Technology Baseline and Standard Scenarios web page: atb.nrel.gov) can be simplified for each technology. 
For wind, the following equation is used to calculate LCOE:

$$
\mathrm{LCOE}=\frac{(\mathrm{CapEx} \times \mathrm{FCR})+\mathrm{OpEx}}{\left(\mathrm{AEP}_{\text {net }} / 1,000\right)}
$$

where

LCOE $=$ levelized cost of energy (\$/megawatt-hour $[\mathrm{MWh}])$

$\mathrm{FCR}=$ fixed charge rate $(\%)$

CapEx $=$ capital expenditures $(\$ /$ kilowatt $[\mathrm{kW}])$

$\mathrm{AEP}_{\text {net }}=$ net average annual energy production $(\mathrm{MWh} /$ megawatt $[\mathrm{MW}] /$ year $[\mathrm{yr}])$

OpEx $=$ operational expenditures $(\$ / \mathrm{kW} / \mathrm{yr})$.

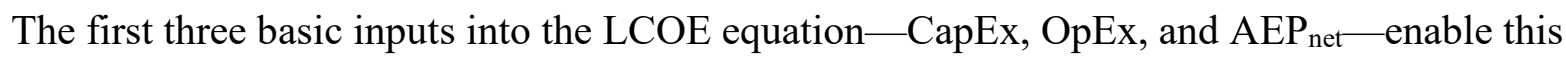
equation to capture system-level impacts from design changes (e.g., larger rotors or taller wind turbine towers). The fourth basic input-FCR - represents the amount of revenue required to pay the annual carrying charges as applied to the CapEx on that investment during the expected project economic life. All analysis and LCOE results are in 2019 U.S. dollars (USD) throughout this report unless otherwise noted. The upcoming sections define the approach to calculating the LCOE following the respective NREL system cost breakdown structures to organize data. This report also describes each component of the LCOE equation (such as CapEx, OpEx, AEP, and FCR), the market context, and a range of data for typical U.S. wind energy projects in 2019. 


\section{U.S. Department of Energy Goals and Reporting Requirements}

Every year, the DOE Wind Energy Technologies Office (WETO) reports the LCOE for landbased and fixed-bottom offshore wind to satisfy GPRA reporting requirements. The annually reported LCOE values are measured against current year and future LCOE targets set by WETO. The official GPRA levelized cost of energy end-point targets presented in this report were set in 2015 for land-based wind and updated in 2019 for fixed-bottom offshore wind. Updates to the LCOE targets are periodically implemented to keep performance measures current with developments in the market and reduce the impact of inflation on LCOE for land-based and offshore wind projects. The GPRA targets are based on trajectories for land-based and fixedbottom offshore ${ }^{5}$ wind projects that span from the current year to 2030. A summary of the GPRA targets for land-based wind is shown in Table 1 and for offshore fixed-bottom wind in Table 2. It is required that each year the actual costs for land-based and fixed-bottom wind LCOE be reported against the GPRA targets. This report provides the cost data to DOE to meet the annual reporting requirement required by the GPRA. The assumptions and calculations for land-based wind and fixed-bottom offshore wind projects used in GPRA reporting are presented in more detail in Section 4.9 and Section 5.9, respectively.

Table 1. Land-Based Wind GPRA Baseline and Target LCOE

\begin{tabular}{|lc|c|}
\hline & 2016 (Baseline) & 2030 (Target) \\
\hline Land-based LCOE $(2015 \$ / \mathrm{MWh})$ & 56 & 23 \\
\hline
\end{tabular}

Note: The GPRA baseline and target levelized cost of energy in Table 1 are reported in 2015 USD for land-based wind because WETO will report land-based wind values in 2015 USD.

Table 2. Offshore Fixed-Bottom Wind GPRA Baseline and Target LCOE

\begin{tabular}{|lc|c|}
\hline & 2019 (Baseline) & 2030 (Target) \\
\hline Offshore fixed-bottom LCOE $(2018 \$ / \mathrm{MWh})$ & 83 & 51 \\
\hline
\end{tabular}

Note: The GPRA baseline and target levelized cost of energy in Table 2 are reported in 2018 USD because WETO will report offshore fixed-bottom wind values in 2018 USD.

\footnotetext{
${ }^{5}$ As of fiscal year 2020, WETO does not report GPRA costs or targets for floating offshore wind or distributed wind technologies.
} 


\section{Approach}

This "2019 Cost of Wind Energy Review" applies a similar approach as the past cost of wind energy review reports (Tegen et al. 2012, 2013; Moné et al. 2015a, 2015b, 2017; Stehly et al. $2017,2018,2019)$. The analysis uses a number of data sources and models to estimate the cost of wind energy. These models and data have been tested, documented, and verified within NREL, other national laboratories, universities, and industry to ensure that the methodology and tools are as accurate as possible. The land-based wind data use the annually released "Wind Technologies Market Report" authored by Lawrence Berkeley National Laboratory. Specific to the "2019 Cost of Wind Energy Review," the data come from Wiser and Bolinger (2020). The market data supporting the offshore wind analysis are limited to international projects and proposed U.S. projects reported in the "2019 Offshore Wind Technologies Update" (Musial et. al. 2020) and stored in NREL's offshore wind database ${ }^{6}$ of global offshore projects. Given the market and model data available, the general approach to estimating the levelized cost of wind energy includes:

- Evaluating market conditions and data for projects that have been installed in the United States in a given year to understand total land-based CapEx, annual energy production (AEP), annual OpEx for recently installed projects, and representative turbine technology. Representative turbine characteristics (i.e., rating, rotor diameter, and hub height) are taken as market averages of the turbines installed in 2019. Accordingly, LCOE estimates reflect average empirical conditions to the extent possible.

- Evaluating market conditions and data for projects that have been installed in Europe and Asia when considering offshore wind technology in a given year to understand total CapEx, OpEx, and representative turbine technology. AEP and balance-of-system (BOS) costs are modeled using the specified U.S. North Atlantic site conditions. The primary sources for these data are NREL's offshore wind database and the "2019 Offshore Wind Technologies Update" (Musial et. al. 2020).

- Supplementing available market data with modeled data based on a representative or reference project that reflects technology and project parameters for a given year. Analysts used the following suite of NREL models to complete the LCOE analysis:

- The 2015 Cost and Scaling Model ${ }^{7}$ (CSM). We used the CSM to estimate utilityscale land-based wind turbine costs using scaling relationships at the component level (e.g., blade, hub, generator, and tower) that reflect the component-specific and often nonlinear relationships between size and cost.

- The Land-Based-Wind BOS model. ${ }^{8}$ We used the BOS model to estimate all other components of the utility-scale land-based wind power plant other than the turbine's tower and rotor nacelle assembly using scaling relationships based on empirical data obtained from a land-based wind developer and wind industry stakeholders.

○ Land-based Balance of System Systems Engineering (LandBOSSE). We used the LandBOSSE model to estimate all BOS components of the residential and

\footnotetext{
${ }^{6}$ NREL's offshore wind database is used as an internal reference and is not publicly available.

${ }^{7}$ NREL's 2015 Cost and Scaling Model is used as an internal reference and is not publicly available.

${ }^{8}$ NREL's Land-Based-Wind Balance of System model is used as an internal reference and is not publicly available.
} 
commercial distributed wind reference projects. This model is based on a bottom-up assessment of inputs and outputs associated with each BOS operation and is supplemented by top-down estimates of costs from industry. Additional details on the model can be found in Eberle et. al. (2019).

- The NREL Offshore Wind Cost $\operatorname{Model}^{9}$ (Beiter et al. 2016). Also referred to as the Offshore Wind Regional Cost Analyzer (ORCA). We used ORCA to estimate offshore turbine costs using scaling relationships from collected global offshore wind industry empirical data and to estimate offshore wind power plant losses and availability.

- The System Advisor Model ( https://sam.nrel.gov/). We used the System Advisor Model to estimate net energy production for land-based wind and ORCA to estimate net energy production for offshore wind power plants based on turbine rated capacity, rotor diameter, hub height, and a representative wind resource.

- Combining the market and modeled data described earlier to estimate the primary elements necessary to calculate LCOE (i.e., CapEx, OpEx, AEP, and FCR) and provide details about wind technology costs and performance that are aligned with market data but reported at a more detailed resolution. Unless specifically stated, all data and analysis used in this report are in 2019 USD, considering changes resulting from inflation from previous reports.

\footnotetext{
${ }^{9}$ We implement continual updates to the NREL Offshore Wind Cost Model to best align with current offshore wind industry data. The NREL Offshore Wind Cost Model is also referred to as the Offshore Regional Cost Analyzer and is used in other forthcoming NREL publications. Details on the updates are presented in Appendix E.
} 


\section{Land-Based Wind}

The turbine characteristics used in the land-based wind reference project were derived from the "2020 Wind Energy Technology Data Update" (Wiser and Bolinger 2020). Reference project wind turbine and component costs are based on a hypothetical wind turbine that comprises the average parameters - nameplate capacity, rotor diameter, and hub height — of turbines that were installed in the United States in 2019. This type of turbine rests on a standard spread-foot foundation design and incorporates a three-stage planetary/helical gearbox feeding a high-speed asynchronous generator. The 2019 reference project wind regime is intended to reflect an International Electrotechnical Commission wind class IIb (IEC 2020). This wind resource site is consistent with prior versions of this report and a typical plant size of $200 \mathrm{MW}$.

\subsection{Land-Based Reference Project}

The land-based reference project is intended to represent a wind site found in the interior region of the United States. The wind power plant specific to this analysis comprises 79 wind turbines that are each rated at 2.6 MW (based on the average wind turbine size installed in the United States in 2019), equating to a capacity of $200 \mathrm{MW}$. These reference project parameters are summarized in Table 3, with further detail on the turbine parameters provided in Table 5. The wind power plant layout is roughly placed in a grid layout at an elevation around 450 meters (m) above sea level - the reference elevation is used for calculating the wind plant's AEP. The wind power plant is assumed to be operating for 25 years with no catastrophic operation and maintenance (O\&M) events.

Table 3. Land-Based Reference Project Parameters

\begin{tabular}{|lc|}
\hline \multicolumn{2}{|c|}{ Project Parameters } \\
\hline Turbine rated power (MW) & 2.6 \\
\hline Number of turbines & 79 \\
\hline Wind plant capacity (MW) & 200 \\
\hline Altitude above mean sea level [measured at turbine foundation (m)] & 450 \\
\hline Project design life (years) & 25 \\
\hline
\end{tabular}

Note: Project design life refers to the time in which the wind power plant is expected to operate (not referring to the turbine's design life for engineering or certification purposes).

\subsection{Land-Based Capital Expenditures}

The weighted-average CapEx data are published annually by DOE (Wiser and Bolinger 2020). We used the NREL 2015 CSM to determine the component cost breakdown given the total CapEx cost estimates reported by Wiser and Bolinger (2020). The NREL 2015 CSM uses curve fits from commercial turbine component design and cost data while providing the ability to adjust inputs, such as overhead, profit, and transportation. Figure 1 illustrates the breakdown of CapEx for the NREL land-based reference project. In the figure, the CapEx component percentages highlighted in shades of green capture the turbine capital cost, the percentages highlighted in blue capture the BOS share of capital costs, and the components highlighted in purple capture the financial CapEx. For information on the assumptions and inclusions of the individual components, see the "2013 Cost of Wind Energy Review" (Moné et al. 2015a). Some costs, such as transportation, are rolled up into higher categories (such as nacelle and blades), as the specific data are difficult to obtain based on a theoretical reference site. 


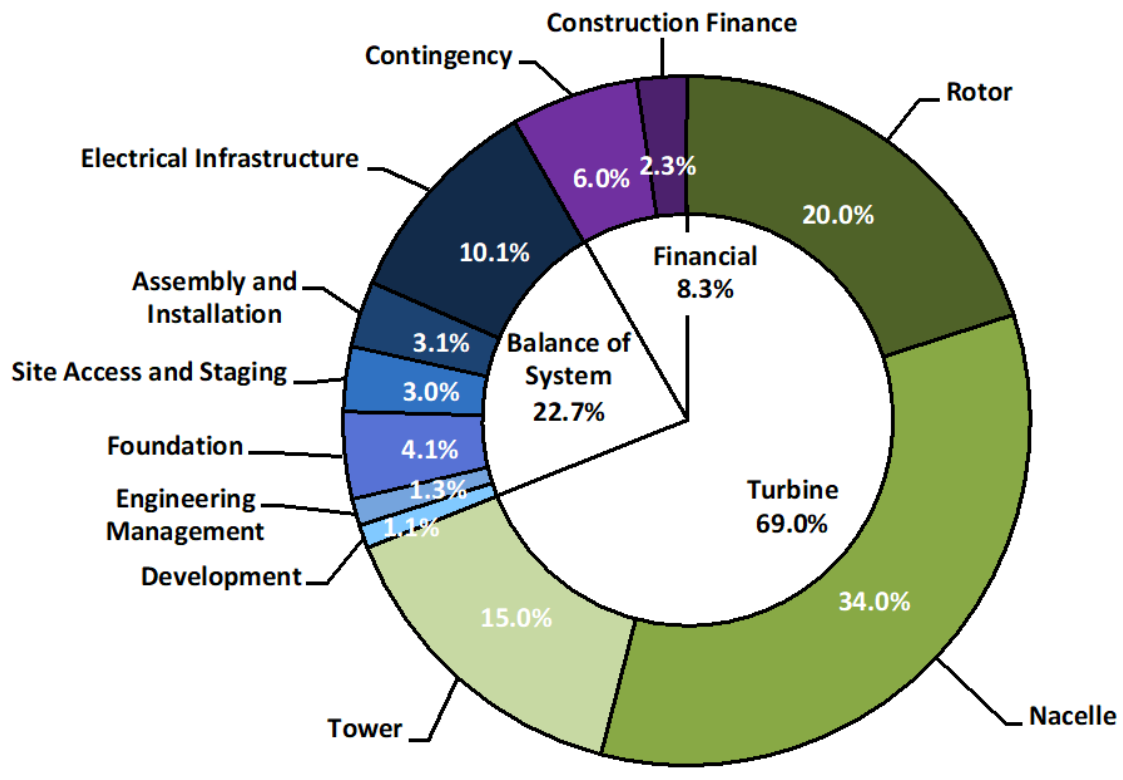

Figure 1. CapEx for the land-based reference wind power plant project

Table 4 summarizes the costs for the reference project's individual components (including their contribution to LCOE). More details on the representative wind power plant's energy production and financial assumptions used to calculate LCOE are provided in Section 4.3 and Section 4.5, respectively. 
Table 4. Land-Based CapEx and LCOE Breakdown

\begin{tabular}{|c|c|c|}
\hline & $\begin{array}{c}\text { 2.6-MW Land-Based } \\
\text { Wind Turbine } \\
\text { (\$/kilowatt [kW]) }\end{array}$ & $\begin{array}{c}\text { 2.6-MW Land-Based } \\
\text { Wind Turbine } \\
\text { (\$/MWh) }\end{array}$ \\
\hline Rotor module & 287 & 5.0 \\
\hline Blades & 184 & 3.2 \\
\hline Pitch assembly & 60 & 1.0 \\
\hline Hub assembly & 44 & 0.8 \\
\hline Nacelle module & 488 & 8.6 \\
\hline Nacelle structural assembly & 98 & 1.7 \\
\hline Drivetrain assembly & 192 & 3.4 \\
\hline Nacelle electrical assembly & 167 & 2.9 \\
\hline Yaw assembly & 32 & 0.6 \\
\hline Tower module & 215 & 3.8 \\
\hline Turbine capital cost & 991 & 17.4 \\
\hline Development cost & 16 & 0.3 \\
\hline Engineering and management & 18 & 0.3 \\
\hline Foundation & 59 & 1.0 \\
\hline Site access and staging & 44 & 0.8 \\
\hline Assembly and installation & 44 & 0.8 \\
\hline Electrical infrastructure & 145 & 2.5 \\
\hline Balance of system & 326 & 5.7 \\
\hline Construction financing cost & 34 & 0.6 \\
\hline Contingency fund & 86 & 1.5 \\
\hline Financial costs & 120 & 2.1 \\
\hline Total capital expenditures & 1,436 & 25.2 \\
\hline
\end{tabular}

Because of CapEx variability among projects, we established estimates for the turbine component costs using the NREL 2015 CSM. We estimated BOS costs using NREL's LandBased-Wind BOS model, which relies on scaling relationships and costs derived from detailed data obtained through a major engineering, procurement, and construction firm active in the wind industry to characterize costs. Construction financing was estimated assuming a 3-year construction duration and distributing the capital and interest over the 3 years. We estimated the project contingency at $6 \%$ of CapEx, which is consistent with industry reporting. Total installed project CapEx for U.S. projects in 2019 came in at \$1,436/kW (Wiser and Bolinger 2020), which 
is a decrease from last year's cost report of $\$ 1,497 / \mathrm{kW}^{10}$ primarily from lower turbine prices in reported installed project costs in 2019.

\subsection{Land-Based Technology Characteristics and Annual Energy Production}

\subsubsection{Turbine Parameters}

For the purpose of this report, the turbine parameters are specific to the turbine and independent of the wind resource characteristics. These parameters include not only turbine size (such as rated power, rotor diameter, and hub height), but also turbine operating characteristics (such as coefficient of power, maximum tip speed, maximum tip-speed ratio, and drivetrain design). Because the three-stage planetary/helical gearbox with a high-speed asynchronous generatorstyle drivetrain topology dominates the U.S. market, we selected this type of drivetrain for the baseline wind turbines used in this analysis. The power curve for the 2.6-MW land-based wind turbine is derived from NREL's System Advisor Model. A summary of the turbine parameters is shown in Table 5. For specific approaches regarding additional turbine parameters (e.g., power curves), see the "2010 Cost of Wind Energy Review" (Tegen et al. 2012).

Table 5. Reference Land-Based Wind Turbine Parameters

\begin{tabular}{|lc|}
\hline \multicolumn{1}{|c|}{ Wind Turbine Parameters } \\
\hline Turbine rated power $(\mathrm{MW})$ & 2.6 \\
\hline Turbine rotor diameter $(\mathrm{m})$ & 121.2 \\
\hline Turbine hub height $(\mathrm{m})$ & 90.1 \\
\hline Maximum rotor tip speed (meters per second $[\mathrm{m} / \mathrm{s}])$ & 80 \\
\hline Tip-speed ratio at maximum coefficient of power $\left(\mathrm{C}_{\mathrm{p}}\right)$ & 8 \\
\hline Drivetrain design & Geared \\
\hline Cut-in wind speed $(\mathrm{m} / \mathrm{s})$ & 3 \\
\hline Cut-out wind speed $(\mathrm{m} / \mathrm{s})$ & 25 \\
\hline Maximum coefficient of power & 0.47 \\
\hline
\end{tabular}

\subsubsection{Wind Resource}

The average wind speed varies from project to project across the United States. The annual average wind speed chosen for the reference project analysis, which is consistent with prior reports, is 7.25 meters per second $(\mathrm{m} / \mathrm{s})$ at 50 meters $(\mathrm{m})$ above ground level $(7.89 \mathrm{~m} / \mathrm{s}$ at a hub height of $90.1 \mathrm{~m}$ ). This wind speed is intended to be generally indicative of the wind regime for projects installed in moderate-quality sites (i.e., IEC wind class IIb). We applied an elevation of $450 \mathrm{~m}$ above sea level based on this concept of using a representative site that would have a similar altitude to a project located within the interior of the country. The representative elevation defines the air density used for calculating the project AEP. A summary of the wind resource assumptions for the 2019 representative site is included in Table 6 .

\footnotetext{
${ }^{10}$ For comparison purposes, last year's CapEx was inflated from 2018 USD to 2019 USD assuming a 1.8\% cumulative rate of inflation from the Bureau of Labor and Statistics (undated).
} 
Table 6. Reference Land-Based-Wind Resource Assumptions

\begin{tabular}{|lc|}
\hline \multicolumn{2}{|c|}{ Wind Resource Characteristics } \\
\hline Annual average wind speed at a 50-m height $(\mathrm{m} / \mathrm{s})$ & 7.25 \\
\hline Annual average wind speed at a 90.1-m hub height $(\mathrm{m} / \mathrm{s})$ & 7.89 \\
\hline Weibull k & 2.0 \\
\hline Shear exponent & 0.143 \\
\hline Altitude above mean sea level (measured at turbine foundation $[\mathrm{m}])$ & 450 \\
\hline
\end{tabular}

\subsubsection{Losses and Availability}

Although some losses can be affected by turbine design or wind resource characteristics, they are treated as independent of any other input in this simplified analysis. Types of losses accounted for here include array wake losses, electric collection and transmission losses (from the substation to the point of interconnection), and blade soiling losses, totaling $15 \%$. A wind power plant availability of $98 \%$ is assumed, indicating the plant is ready to produce power $98 \%$ of the time that the wind speed falls within the operational range (i.e., between the wind turbine's cut-in and cut-out wind speeds). Wind plant availability accounts for any unplanned downtime the plant may experience such as unplanned maintenance activities. The net average AEP is then calculated by applying all losses and availability to the gross AEP. Table 7 shows the estimated losses and availability for the land-based reference wind power plant.

Table 7. Reference Land-Based-Wind Losses and Availability Assumptions

\begin{tabular}{|ll|}
\hline \multicolumn{2}{|c|}{ Losses } \\
\hline Losses (i.e., array, energy conversion, and line) & $15 \%$ \\
\hline Availability & $98 \%$ \\
\hline
\end{tabular}

\subsubsection{Annual Energy Production}

The AEP for this analysis was computed using the System Advisor Model. The model uses an idealized power curve based on the turbine configuration and computes annual energy capture for a wind project that is specified by the wind resource and the wind power plant's assumed losses and availability. The result of these calculations yields a net energy capture of 3,734 $\mathrm{MWh} / \mathrm{MW} / \mathrm{year}$, which corresponds to a $42.6 \%$ net capacity factor assuming 8,760 hours in a year. For reference, the average capacity factor reported by Wiser and Bolinger (2020) in calendar year 2019 is $41 \%$ for projects built from 2014 to 2018 . The net energy capture and net capacity factor for the reference wind plant are shown in Table 8.

Table 8. Reference Land-Based-Wind Power Plant AEP and Capacity Factor Summary

\begin{tabular}{|lc|}
\hline \multicolumn{2}{|c|}{ AEP and Capacity Factors } \\
\hline Net energy capture (MWh/MW/year) & $7.25 \mathrm{~m} / \mathrm{s}$ at $50 \mathrm{~m}$ \\
\hline Net capacity factor $(\%)$ & 3,734 \\
\hline
\end{tabular}




\subsection{Land-Based Operation and Maintenance Expenditures}

OpEx costs are generally expressed in two categories: 1) fixed O\&M costs (e.g., scheduled plant maintenance or land lease costs) and 2) variable O\&M costs (e.g., unscheduled plant maintenance). For simplicity, annual OpEx can be converted to a single term and expressed as either dollars per kilowatt per year $(\$ / \mathrm{kW} / \mathrm{yr})$ or dollars per megawatt-hour $(\$ / \mathrm{MWh})$. This analysis uses the dollars-per-kilowatt-per-year convention. O\&M market data are not widely available; therefore, the recent U.S. wind industry survey, "Assessing wind power operating costs in the United States: Results from a survey of wind industry experts" (Wiser et al. 2019) is used to inform the O\&M cost estimates for the representative wind plant. For recently installed projects, entering commercial operations from 2015 through 2018, the survey results anticipate an average range of O\&M costs between $\$ 33$ and $\$ 59 / \mathrm{kW} / \mathrm{yr}$. The average across respondents was $\sim \$ 43 / \mathrm{kW} / \mathrm{yr}$ and is assumed to be the all-in levelized OpEx for the representative project. ${ }^{11}$ The annual O\&M cost from the expert survey and the calculated O\&M cost on an energy basis for the representative wind power plant is shown in Table 9.

Table 9. Land-Based-Wind Reference Project OpEx

\begin{tabular}{|ccc|}
\hline & $\begin{array}{c}2.6-M W \\
\text { Wind Turbine } \\
(\$ / k W / y r)\end{array}$ & $\begin{array}{c}\text { 2.6-MW Land-Based } \\
\text { Wind Turbine }\end{array}$ \\
OpEx & 43 & 11.5 \\
\hline
\end{tabular}

\subsection{Land-Based-Wind Finance}

This section describes the financing assumptions for the report's representative land-based-wind reference project in the United States in 2019. It is important to distinguish between financing assumptions and financial costs. Financial costs, which are part of CapEx according to the system cost breakdown structure, include items such as insurance, contingency, and reserve accounts. Financing assumptions, on the other hand, refer to the cost of interest and other carrying charges, corporate taxes, and depreciation (represented by the FCR in this report), applied to the total CapEx. To capture the financing structure and costs, we use a fixed charge rate, detailed in Section 4.5.2, for the LCOE equation.

\subsubsection{Discount Rate}

Typically, various financial terms, such as the cost of debt or equity, are captured in the discount rate, which is in turn used to estimate the cost of energy. For this analysis, we calculate the discount rate as the after-tax weighted-average cost of capital (WACC), and we presume that the reported yields for equity are after-tax yields and can be used directly in the WACC calculation. The cost of debt (as a value) is also reported, but because interest on debt is tax deductible, we use an effective corporate marginal tax rate to determine an after-tax cost of debt for the discount rate calculation. The cost of capital data collected by Lawrence Berkeley National Laboratory (Wiser and Bolinger 2020) gives a basis for WACC assumptions for the representative wind project in 2019 and results in a nominal WACC of $6.32 \%$. This WACC was derived assuming a debt fraction of $50.3 \%$, nominal debt interest rate of $3.6 \%$, nominal return on equity of $10 \%$, and

\footnotetext{
${ }^{11}$ Given the scarcity and varying quality of the data, OpEx may vary substantially among projects, and the data included here may not fully represent the challenges that OpEx present to the wind power industry.
} 
a $25.7 \%$ tax rate. $^{12}$ Each actual project, however, has a unique risk profile, financing terms, and ownership structure. For this reason, a single WACC representing the entire fleet of 2019 wind installations should be viewed cautiously and used to illustrate general market trends and conditions only.

In financial modeling, corporate tax rates are often presented as a composite, or effective, tax rate. This rate is calculated from a blend of the highest marginal corporate tax rate of $21 \%{ }^{13}$ and an approximate typical state corporate tax rate. Because state taxes are normally deductible expenses on federal tax returns, the blended rate is represented as $25.7 \%$, as reported in NREL's ATB. Wind projects are often organized as disregarded entities for tax purposes (i.e., no taxes are paid by the project entity) and taxes are paid further up the organizational structure at some corporate level.

The inflation rate has been set to $2.5 \%$. This rate aligns with the inflation rate provided in NREL's ATB. Discount rates are initially calculated in nominal after-tax USD, and an estimate of inflation is used to calculate a discount rate in real after-tax USD.

Although the PTC is a critical component for wind projects installed in 2019, it is expected to phase out in future years. ${ }^{14}$ Research has shown that one likely outcome of the termination of the PTC is increased project leverage, which will reduce the higher-cost tax-equity portion of project finance. This shift of capital structure is expected to partially offset the impact of the lack of PTC (Bolinger 2014).

\subsubsection{Economic Evaluation Metrics}

In the economic evaluation of wind energy investments there are two important metrics: the capital recovery factor (CRF) and FCR. The FCR represents the amount of annual revenue required to pay the carrying charge ${ }^{15}$ as applied to the CapEx on that investment during the expected project economic life. ${ }^{16}$ The FCR is based on the capital recovery factor but also reflects corporate income taxes and depreciation. The ATB methodology is used to calculate the FCR.

\footnotetext{
${ }^{12}$ Because these data are derived from installed projects in 2019, they include the impact of the PTC on the debt ratio even though the LCOE estimates do not include the PTC.

${ }^{13}$ The U.S. tax reform bill passed and signed into law in December 2017 (Tax Cuts and Jobs Act, H.R. 1) lowers the corporate tax rate from $35 \%$ to $21 \%$; hence, the $21 \%$ corporate tax rate is used in this year's report assuming the final investment decisions for projects commissioned in 2019 would have been made under the reformed corporate tax rate.

14 "In December 2015, Congress passed a 5-year phased-down extension of the PTC. To qualify, projects must begin construction before January 1, 2020. In May 2016, the IRS issued guidance allowing four years for project completion after the start of construction, without the burden of having to prove continuous construction. In extending the PTC, Congress also included a periodic reduction in the value of the credit for projects starting construction after 2016. Specifically, the PTC will phase down in increments of 20 percentage points per year for projects starting construction in 2017 (80\% PTC), 2018 (60\%), and 2019 (40\%)" (Wiser and Bolinger 2016). Although the PTC was scheduled to phase out completely by the end of 2019, a change to the year-end tax package in 2019 has extended the PTC through the end of 2020 (40\%) (Amendment to Rules Committee Print 116-44. Sec. $127[2019])$.

${ }^{15}$ Carrying charges include the return on debt, return on equity, taxes, and depreciation.

${ }^{16}$ The FCR does not allow for detailed analysis of specific financing structures; however, these structures can be represented through the use of a WACC as the discount rate input.
} 
The CRF is defined as "the uniform periodic payment, as a fraction of the original investment cost that will fully repay a loan including all interest, over the term of the loan" (Short et al. 1995). The CRF can be thought of as the recurring fixed payment over the life of a loan common to most types of mortgages. Note, the CRF ignores the impact of corporate income taxes, thus is applicable to a no-tax investment scenario, such as from a government investment.

A reasonable assumption for land-based wind projects is that $95 \%$ of the project capital cost is eligible for 5-year (Modified Accelerated Cost Recovery System [MACRS]) depreciation, and the balance of the project capital cost is eligible for 15-year MACRS. In this work, the MACRS assumption is further simplified by assuming that $100 \%$ of the wind project cost basis is eligible for 5-year MACRS.

Table 10 presents the estimated WACC, CRF, and FCR in nominal and real terms using the after-tax WACC discount rate of $6.32 \%$ and $3.72 \%$, respectively, a project design lifetime of 25 years, and a net present value depreciation factor of $84.6 \%$ (assuming a 5-year MACRS depreciation schedule). The nominal and real CRF are estimated at $8.06 \%$ and $6.21 \%$, respectively. The nominal FCR is estimated at $8.49 \%$ and the real FCR is estimated at $6.55 \%$. As noted in Short et al. (1995), comparisons of two or more capital investments should be on a consistent tax treatment basis (i.e., both investments using a before-tax method or an after-tax method).

Table 10. Summary of Land-Based-Wind Reference Project Economic Evaluation Metrics

\begin{tabular}{|lcc|}
\hline Weighted-average cost of capital (\%) & Nominal & Real \\
\hline Capital recovery factor (\%) & $8.06 \%$ & $3.72 \%$ \\
\hline Fixed charge rate (\%) & $8.49 \%$ & $6.21 \%$ \\
\hline
\end{tabular}

\subsection{Land-Based-Wind Levelized Cost of Energy}

The levelized cost of energy for the 2019 representative land-based wind power plant is calculated using the formulation presented in NREL's ATB and the representative turbine technology parameters, site conditions, wind resource, and cost estimates (i.e., CapEx, FCR, OpEx, and AEP). The LCOE value for the 2019 representative plant is estimated at $\$ 37 / \mathrm{MWh}$. Table 11 summarizes the costs for the primary components on a per-kilowatt and per-megawatthour basis. The graphic in Figure 2 illustrates the LCOE breakdown for the primary components of the representative wind power plant, whereas Figure 3 depicts the absolute LCOE values for each of the components. 
Table 11. Summary of Inputs and Reference Project LCOE for 2019 Land-Based Installations

\begin{tabular}{|c|c|c|}
\hline & $\begin{array}{c}\text { 2.6-MW Land-Based } \\
\text { Wind Turbine } \\
(\$ / k W)\end{array}$ & $\begin{array}{c}\text { 2.6-MW Land-Based } \\
\text { Wind Turbine } \\
\text { (\$/MWh) }\end{array}$ \\
\hline Turbine capital cost & 991 & 17.4 \\
\hline Balance of system & 326 & 5.7 \\
\hline Financial costs & 120 & 2.1 \\
\hline CapEx & 1,436 & 25.2 \\
\hline OpEx (\$/kW/yr) & 43 & 11.5 \\
\hline Fixed charge rate (real) [\%] & \multicolumn{2}{|c|}{$6.5 \%$} \\
\hline Net annual energy production (MWh/MW/yr) & \multicolumn{2}{|c|}{3,734} \\
\hline Net capacity factor $(\%)$ & \multicolumn{2}{|c|}{$42.6 \%$} \\
\hline TOTAL LCOE (\$/MWh) & \multicolumn{2}{|c|}{37} \\
\hline
\end{tabular}

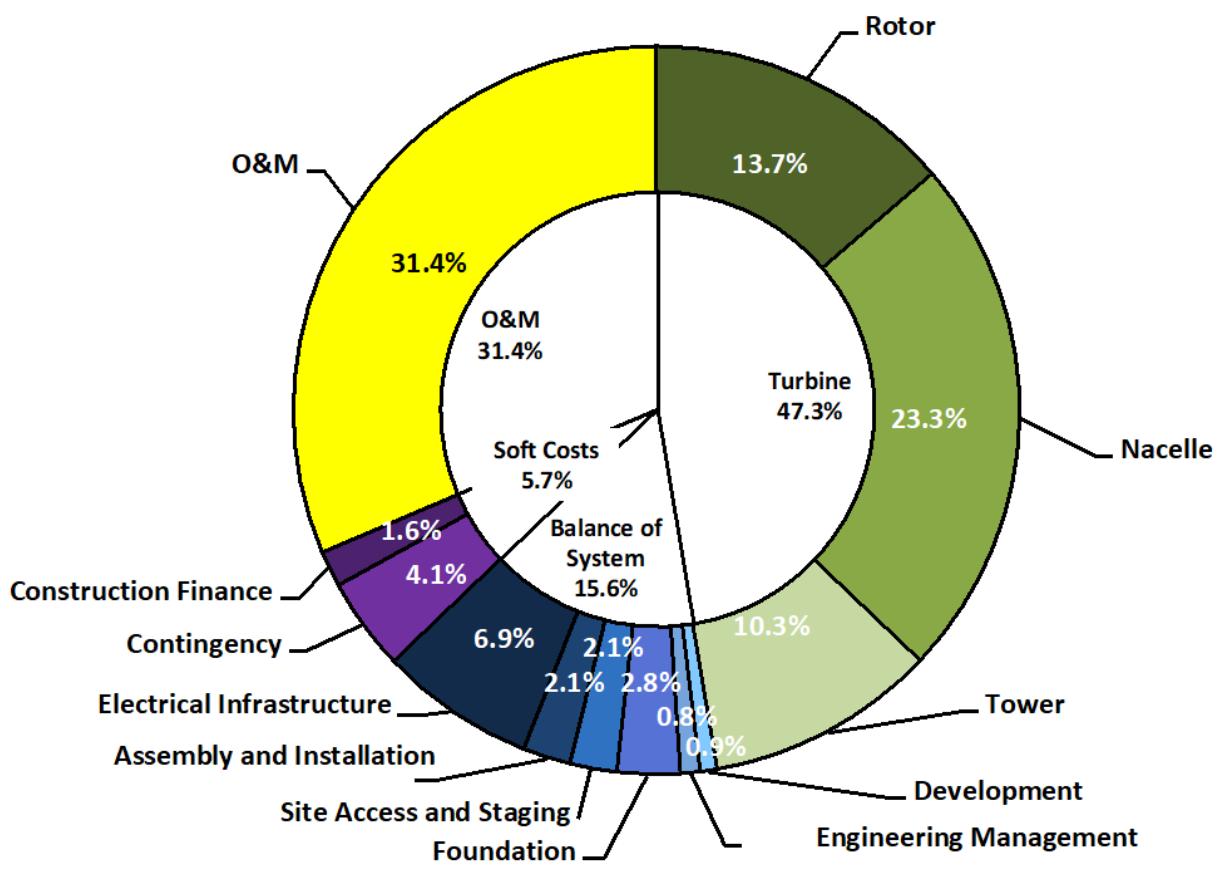

Figure 2. Component-level LCOE contribution for the 2019 land-based-wind reference project operating for 25 years 


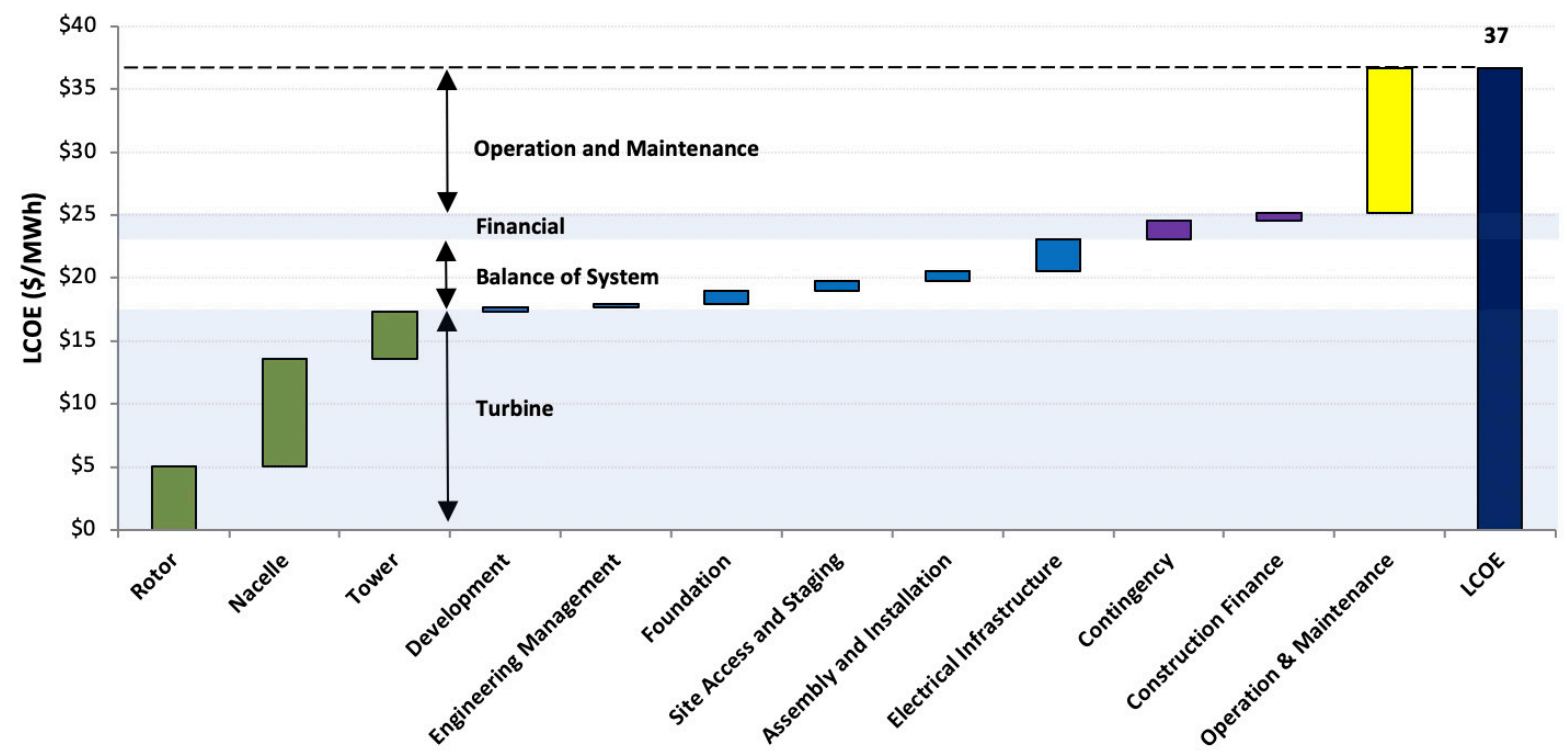

Figure 3. Component-level LCOE breakdown for the 2019 land-based-wind reference project

\subsection{Land-Based-Wind Levelized Cost of Energy Sensitivities}

The input parameters described earlier reflect the land-based reference wind project; however, input parameters for a near-term wind project are subject to considerable uncertainty. As a result, it is beneficial to investigate how this variability may impact the LCOE. The sensitivity analysis shown in Figure 4 focuses on the basic LCOE inputs: CapEx, OpEx, capacity factor, and FCR, which is broken into its principal elements: discount rate and economic operational lifetime.

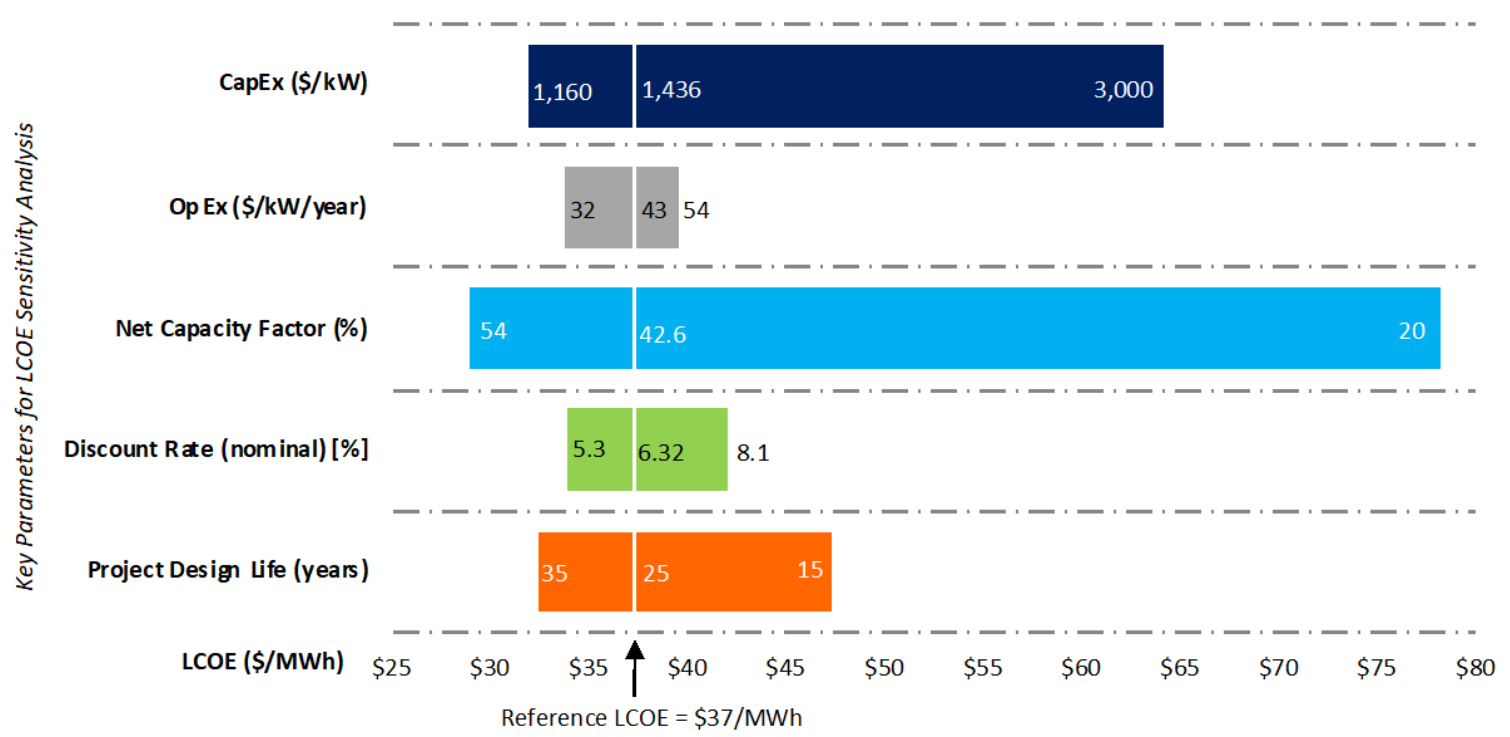

Figure 4. Sensitivity of land-based-wind LCOE to key input parameters

Note: The reference LCOE reflects a representative industry LCOE. Changes in LCOE for a single variable can be understood by moving to the left or right along a specific variable. Values on the x-axis indicate how the LCOE will change as a given variable is altered and all others are assumed constant (i.e., remain reflective of the reference project). 
Sensitivity analyses are conducted by holding all reference project assumptions constant and altering only the variable in question. Sensitivity ranges for all parameters except for project design life are pulled from representative industry data or analysis contained in the "Wind Energy Technology Data Update" (Wiser and Bolinger 2020). This selection of ranges provides insight into how real-world ranges influence LCOE. Keeping the same 200-MW project size, the sensitivity analysis yields ranges in LCOE from a low of $\$ 29 / \mathrm{MWh}$ to a high of $\$ 78 / \mathrm{MWh}-\mathrm{a}$ low-to-high delta of $\$ 49 / \mathrm{MWh}$. Within the ranges shown, net capacity factor has the greatest impact on land-based-wind LCOE followed by impacts from CapEx and then project design life. Net capacity factor appears to have the greatest influence with respect to decreasing the LCOE relative to the reference project.

\subsection{Land-Based Supply Curve}

The land-based supply curve illustrates LCOE across the contiguous United States using the 2019 market data from Wiser and Bolinger (2020) and the Wind Integration National Dataset Toolkit (https://www.nrel.gov/grid/wind-toolkit.html). The toolkit provides meteorological conditions for more than 126,000 sites in the continental United States for the years 2007 to 2013. The LCOE for each of the potential wind power plant locations is computed using a sitespecific CapEx and net AEP using a geographic-information-system-based algorithm. The estimated theoretical capacity for the United States is calculated to be over 9,000 gigawatts $(\mathrm{GW})$, assuming a wind power plant density of $3 \mathrm{MW} /$ square kilometer $\left(\mathrm{km}^{2}\right)$. The LCOE calculated for this theoretical capacity ranges from $\$ 29 / \mathrm{MWh}$ for the best sites in the United States and extends beyond $\$ 200 / \mathrm{MWh}$ for nonideal sites. Figure 5 shows this supply curve. For illustrative purposes, the LCOE is calculated for the land-based wind projects installed in 2019 using the same site-specific methodology for 80 project locations, which are shown on the supply curve (marked by green circles). In the figure, most of the installed projects in 2019 are grouped near the left side of the supply curve, where LCOE values are lowest, with fewer scattered when moving toward the right of the supply curve with higher LCOE values. Also shown is the calculated LCOE for the reference land-based wind project (indicated by the orange diamond), which is based on the 2019 market data from Wiser and Bolinger (2020) and the representative wind site characteristics.

It is important to note that the potential wind power plant capacity available over a range of LCOE varies by geographic region primarily because of the available wind resource characteristics. Incremental costs associated with labor rates, material costs, logistical or siting challenges, and distance to existing transmission infrastructure also contribute to regional differences. This range of costs is illustrated in the supply curve (Figure 5), wherein the cluster of installed wind projects in 2019 is toward the lower LCOE end of the supply curve and reflects projects built in the interior region of the United States where the wind resource is favorable. On the other side of the spectrum, the higher LCOE values on the supply curve reflect sites with a relatively lower-quality wind resource and may occur in many regions of the country depending on local meteorological and terrain features. 


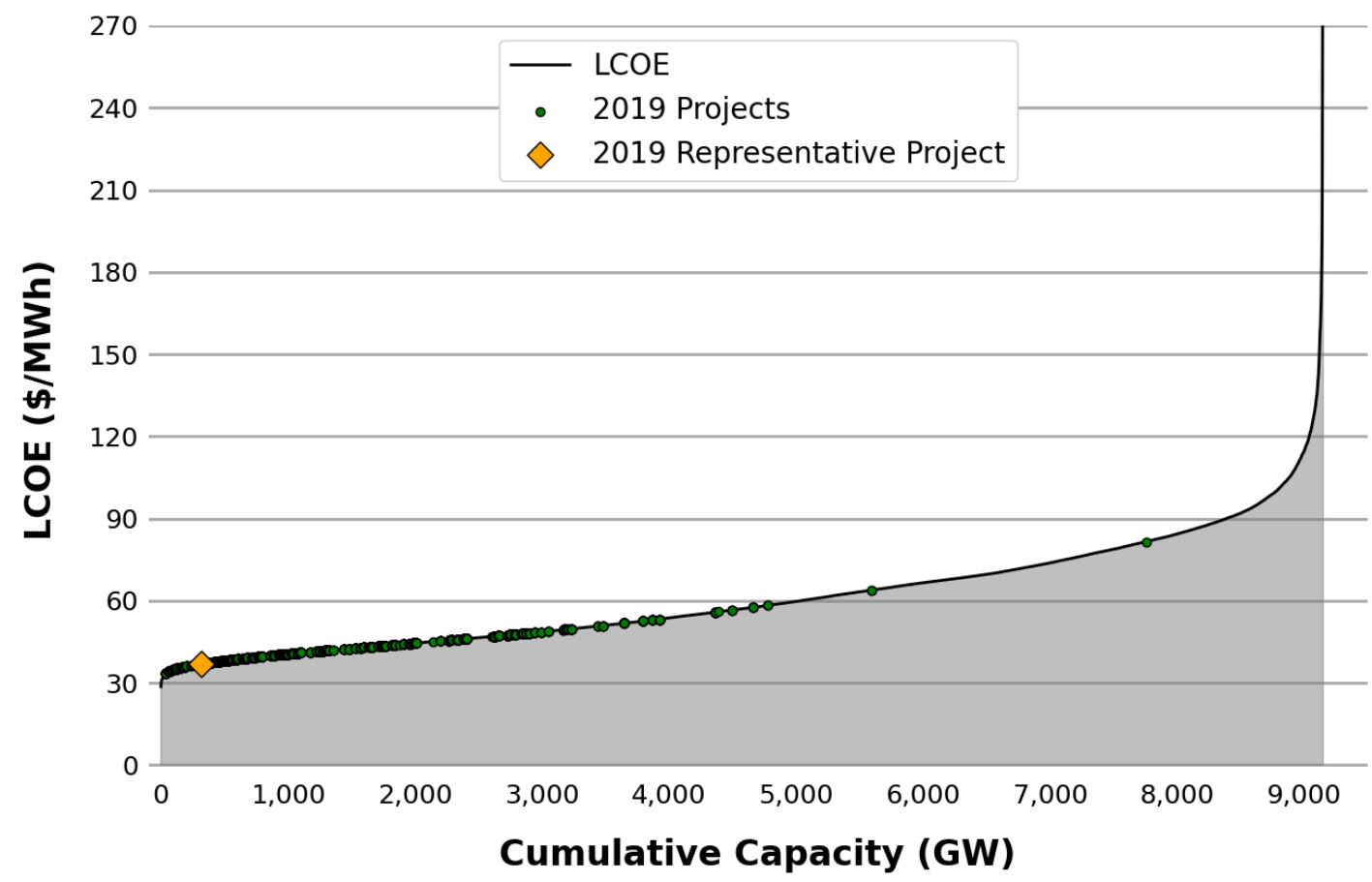

Figure 5. National land-based-wind resource supply curve with 2019 U.S. installed projects

\subsection{Land-Based-Wind Discussion of Results in Context of DOE Goals}

In this section, we present the official land-based-wind GPRA levelized cost of energy end-point target in 2030. The GPRA trajectory starts at \$56/MWh (in 2015 USD) in 2016, which was baselined in 2015, and is projected to the \$23/MWh (in 2015 USD) target in 2030. The 2030 target is derived from the analysis conducted in "Enabling the SMART Wind Power Plant of the Future Through Science-Based Innovation" (Dykes et al. 2017). The pathway for LCOE reduction from the 2015 baseline to the 2030 target is primarily driven by the increase in AEP through turbine scaling, enhanced control strategies, and reducing wind power plant losses (\$20/MWh [in 2015 USD]). The secondary driver in decreasing LCOE is through reductions in CapEx from wind power plant economies of scale, turbine scaling, and efficient manufacturing capabilities (\$8/MWh [in 2015 USD]). The remaining LCOE reductions are derived from decreasing OpEx through advanced O\&M strategies (\$4/MWh [in 2015 USD]) and lowering the cost of capital from increased certainty of future plant performance and reduced risk $(\$ 1 / \mathrm{MWh}$ [in 2015 USD]). This LCOE reduction pathway is illustrated in Figure 6. 


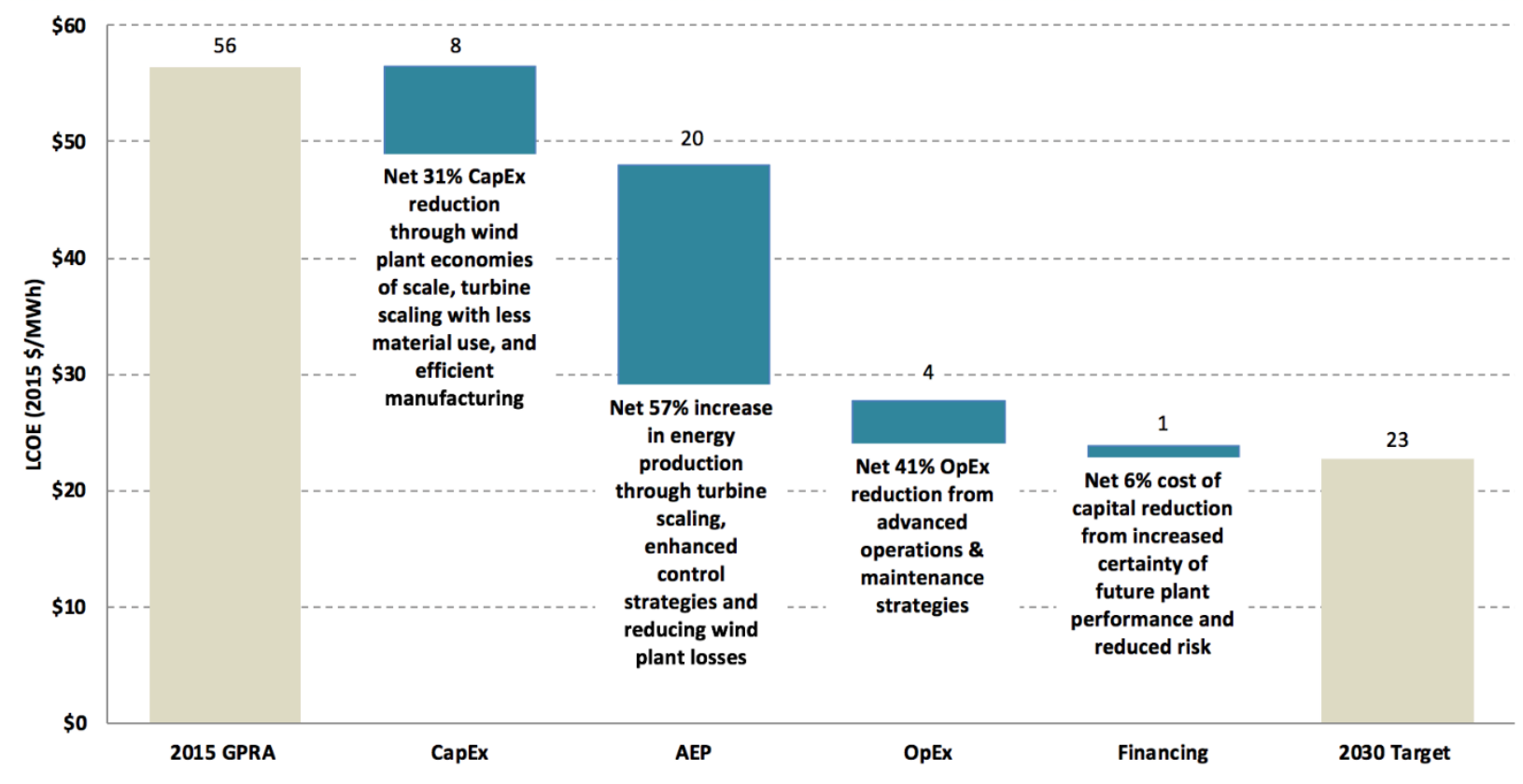

Figure 6. Pathway to LCOE reduction in 2030 by LCOE parameter

The GPRA trajectory and 2030 target are shown in Figure 7. To track LCOE progress against the GPRA trajectory, the historical LCOE (starting from the 2016 baseline year) and the current LCOE value (in 2020) assessed in this year's report are plotted. The GPRA baseline and target levelized cost of energy are reported in 2015 USD for land-based wind because WETO will report land-based wind values in 2015 USD. The current and historical LCOE values are labeled as "Actuals" in Figure 7. In the figure, the 2020 actual LCOE is reported as \$34/MWh instead of $\$ 37 / \mathrm{MWh}$, as it was converted from 2019 USD to 2015 USD to compare against the GPRA trajectory. ${ }^{17}$

${ }^{17}$ The 2019 USD to 2015 USD was calculated assuming a $-7.3 \%$ cumulative rate of inflation from the Bureau of Labor and Statistics (undated). 


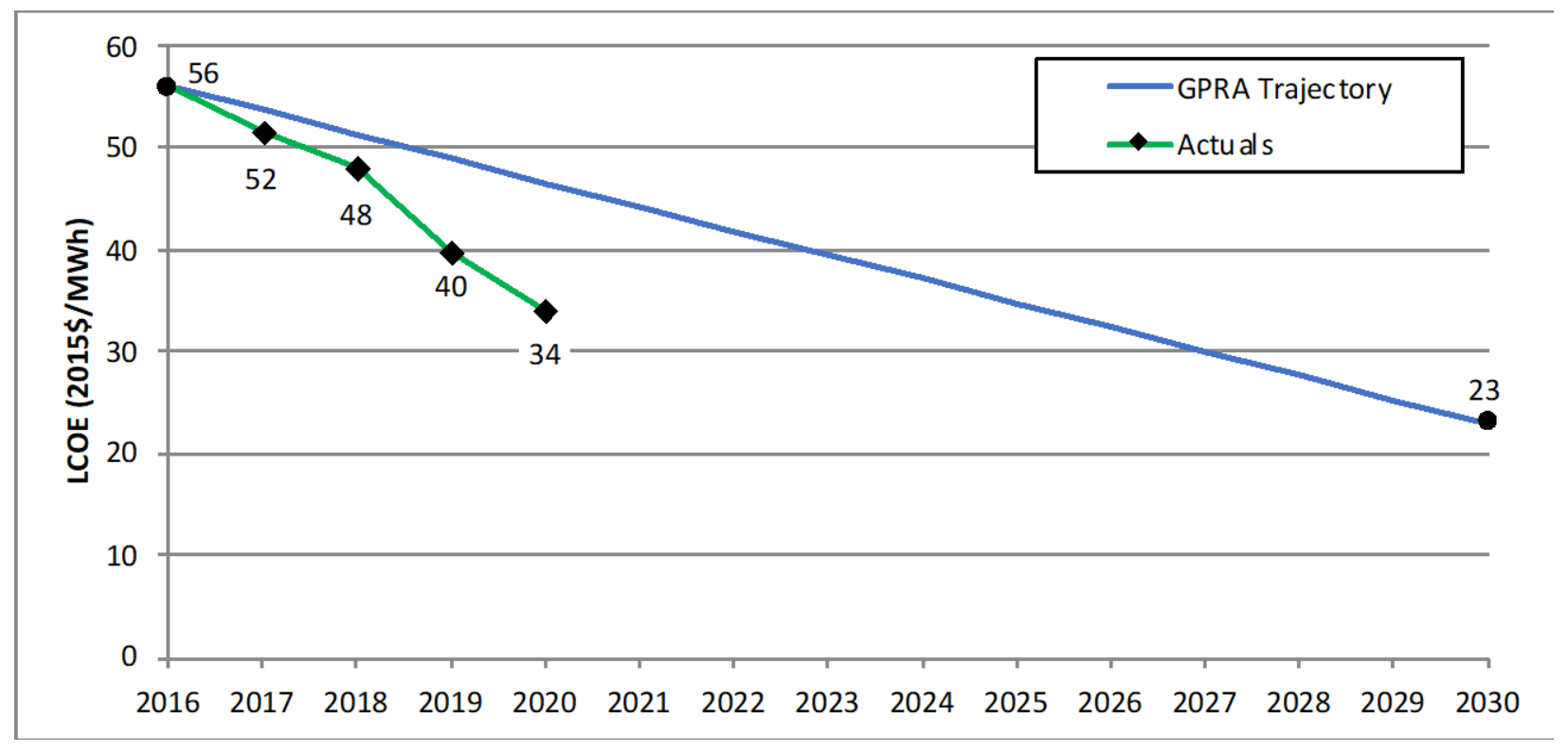

Figure 7. Land-based wind GPRA cost trajectories for LCOE (in 2015 USD)

Note: The drop in LCOE between 2019 and 2020 is largely because of updates made to the financing assumptions. Prior to the "2018 Cost of Wind Energy Review," WETO reported land-based financing using a constant and conservative FCR. The landbased FCR is updated in 2020 to maintain reporting consistency between land-based wind and offshore wind technologies. Landbased-wind cost of capital data collected by Lawrence Berkeley National Laboratory (Wiser and Bolinger 2020) gives a basis for WACC assumptions for the representative wind project in 2019 and results in a nominal WACC of $6.32 \%$. A sensitivity analysis using the finance assumptions in last year's cost report is captured in Appendix A. 


\section{Offshore Wind}

This section explains the methodology and assumptions of calculating LCOE for U.S. offshore wind with each subsection detailing the data and assumptions used. The data from this analysis are derived from NREL's internal offshore wind database, which is populated with U.S. and global market data. Market trends for offshore wind costs in Europe have informed the internal NREL modeling for this assessment and cost projections for the United States. The analysis uses updated data and information from the "2019 Offshore Wind Technologies Update" (Musial et. al. 2020) and NREL's 2020 ATB for offshore wind. In this report, we updated costs and financial parameters to conform with the most recent industry and market developments. The offshore wind reference sites used for this assessment are those that have been introduced in the "2018 Cost of Wind Energy Review." These reference sites reflect spatial conditions that are intended to represent near- to medium-term U.S. project development. Additional details are provided in Section 5.1 and Appendix C.

\subsection{Offshore Reference Project}

For the purposes of this study, two offshore wind technology categories are assessed: fixed bottom and floating. The two substructure technologies are used in different site conditions; hence, this analysis considers two separate offshore reference sites (one for fixed bottom and one for floating). The two reference sites are used to calculate LCOE for each of the technologies; however, the fixed-bottom site is used for GPRA reporting.

We assessed a reference project at the fixed-bottom and floating sites, which each comprise 100 wind turbines rated at 6.1 MWs - the turbine capacity estimated from NREL's global offshore wind project database for calendar year 2019. A total wind power plant capacity of $600 \mathrm{MW}$ is assumed. ${ }^{18}$ The turbines are oriented in a grid layout and are expected to operate for 25 years without any catastrophic O\&M events. Turbines at the fixed-bottom reference site are assumed to be supported by a monopile substructure $50 \mathrm{~km}$ from cable landfall at a water depth of $34 \mathrm{~m}$, which is similar to the characteristics of the wind energy areas located in the North Atlantic region. At the floating reference site, the wind turbines are assumed to be held by a semisubmersible substructure $36 \mathrm{~km}$ from cable landfall at a water depth of $739 \mathrm{~m}$, which is analogous to features of the Pacific Coast. Additional information on the types of fixed-bottom and floating wind substructures can be found in Musial et al. (2017).

The array cable system and electrical line that connects to the offshore substation is a 33-kilovolt collection system design. The export cable from the offshore substation that is used to transfer the power to landfall assumes a 220-kilovolt export system. Specific to the floating reference site, cost premiums are applied to the array and export cable systems to account for the use of dynamic cables. A summary of the two offshore reference site characteristics is provided in Table 12. Further details on the development of the fixed-bottom and floating reference sites are presented in Appendix C.

\footnotetext{
${ }^{18}$ Note that technically, 100 turbines with a turbine rating of $6.1 \mathrm{MW}$ would yield a plant capacity of $610 \mathrm{MW}$; however, for cost modeling purposes, a plant size of $600 \mathrm{MW}$ is assumed.
} 
Table 12. Offshore Reference Project Parameters (Fixed-Bottom and Floating Substructures)

\begin{tabular}{|c|c|c|}
\hline \multicolumn{3}{|c|}{ Project Parameters } \\
\hline & Fixed Bottom & Floating \\
\hline Region & North Atlantic & Pacific Coast \\
\hline Turbine rated power (MW) & 6.1 & 6.1 \\
\hline Number of turbines & 98 & 98 \\
\hline Wind plant capacity (MW) & 600 & 600 \\
\hline Water depth $(\mathrm{m})$ & 34 & 739 \\
\hline Substructure type & Monopile & Semisubmersible \\
\hline Distance from shore $(\mathrm{km})$ & 50 & 36 \\
\hline Project design life (yr) & 25 & 25 \\
\hline
\end{tabular}

\subsection{Offshore Capital Expenditures}

We estimated CapEx using ORCA (Beiter et al. 2016). The representative turbine characteristics (i.e., turbine capacity, rotor diameter, and hub height) used as inputs to the model were obtained from NREL's global offshore wind database (documented last in the "2018 Offshore Wind Technologies Market Report" [Musial et al. 2019]). The capacity-weighted average turbine installed globally in 2019 was $6.1 \mathrm{MW}$, with a 151-m rotor diameter at a 101.8-m hub height. We used these turbine parameters in combination with the spatial parameters presented in Table 12 for the fixed-bottom and floating reference sites to calculate CapEx.

The ORCA model yields a total installed CapEx value of $\$ 4,077 / \mathrm{kW}$ for the fixed-bottom reference site and $\$ 5,328 / \mathrm{kW}$ for the floating reference site. It should be noted that the CapEx estimates for floating offshore wind in this analysis assume a 6.1-MW turbine and are not necessarily optimized for floating offshore wind applications; therefore, they may negatively impact the floating CapEx estimates. Progression to larger turbines is likely to coincide with deployment of commercial-scale floating wind technologies (Spyroudi 2016).

A breakdown of the CapEx for the fixed-bottom offshore reference project is shown in Figure 8. The shades of green represent the turbine cost, shades of blue represent BOS costs, and shades of purple represent financial costs. Further details on the BOS cost breakdown are provided in Maness et al. (2016). The dollar-value component cost breakdown is shown in Table 13. Figure 9 and Table 14 describe the same breakdown for the floating offshore reference project. 


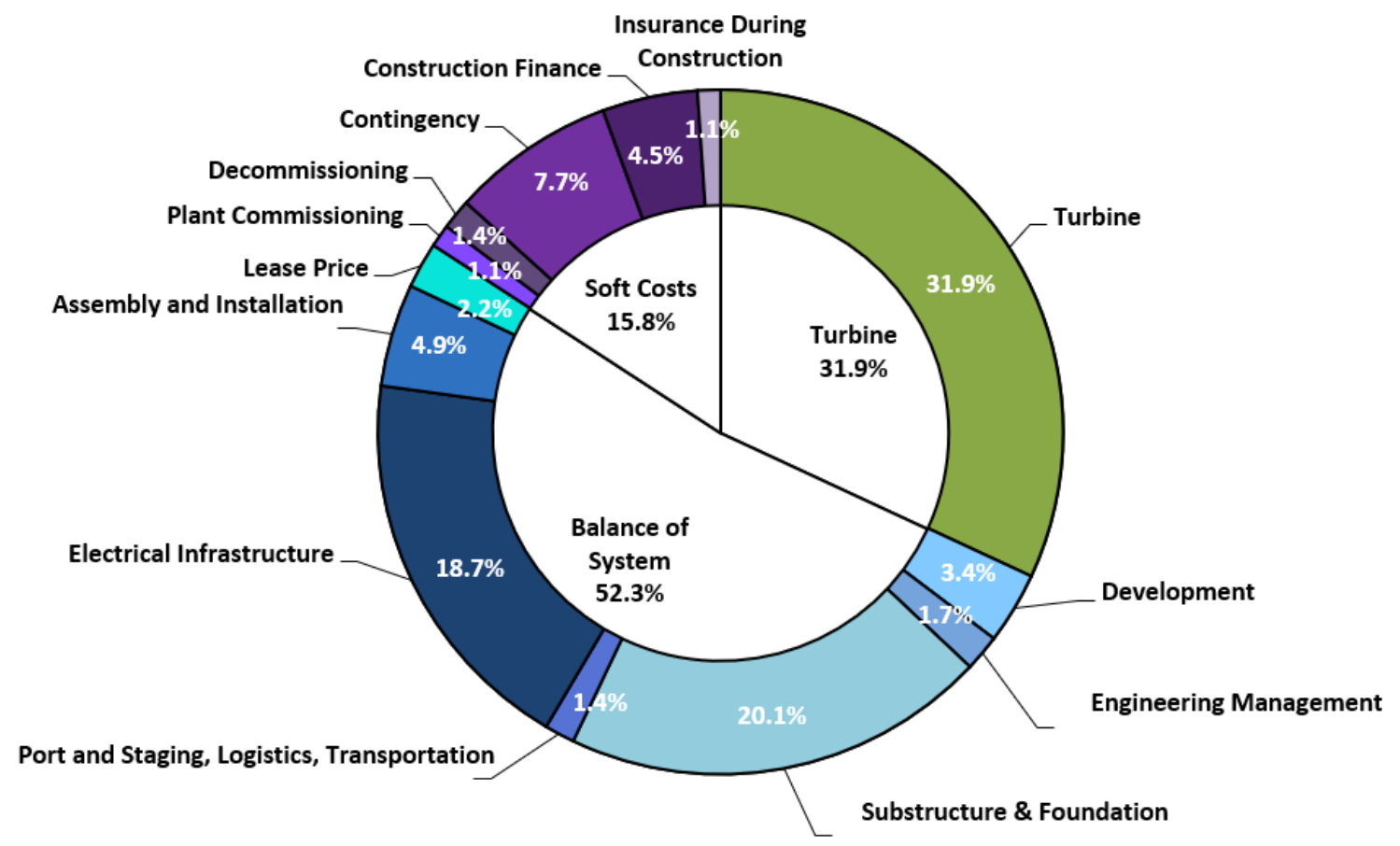

Figure 8. Capital expenditures for the fixed-bottom offshore wind reference project 
Table 13. Fixed-Bottom Offshore CapEx and LCOE Breakdown

\begin{tabular}{|c|c|c|}
\hline & $\begin{array}{l}\text { 6.1-MW Fixed-Bottom } \\
\text { Offshore Wind Turbine } \\
\qquad(\$ / k W)\end{array}$ & $\begin{array}{l}\text { 6.1-MW Fixed-Bottom } \\
\text { Offshore Wind Turbine } \\
\text { (\$/MWh) }\end{array}$ \\
\hline TURBINE CAPITAL COST & 1,301 & 17.7 \\
\hline Development cost & 138 & 1.9 \\
\hline Engineering and management & 70 & 1.0 \\
\hline Substructure and foundation & 817 & 11.1 \\
\hline Port and staging, logistics, transportation & 58 & 0.8 \\
\hline Electrical infrastructure & 761 & 10.4 \\
\hline Assembly and installation & 198 & 2.7 \\
\hline Lease price & 88 & 1.2 \\
\hline BALANCE OF SYSTEM & 2,131 & 29.0 \\
\hline Insurance during construction & 44 & 0.6 \\
\hline Decommissioning bond & 58 & 0.8 \\
\hline Construction financing & 183 & 2.5 \\
\hline Contingency & 316 & 4.3 \\
\hline Plant commissioning & 44 & 0.6 \\
\hline SOFT COSTS & 645 & 8.8 \\
\hline TOTAL CAPITAL EXPENDITURES & 4,077 & 55.6 \\
\hline
\end{tabular}

Note: Values rounded to the nearest dollar. The electrical infrastructure cost category includes construction and fabrication costs of both the land-based and offshore substations and does not include installation costs for the electrical system, as they are included in the assembly and installation costs.

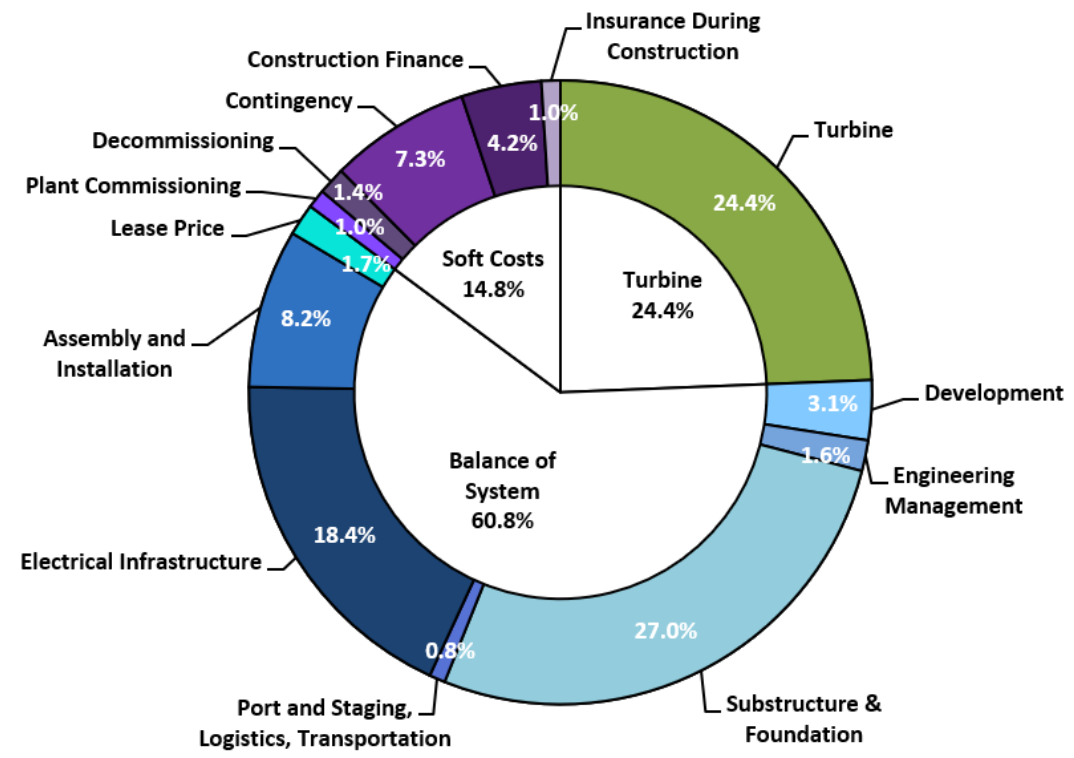

Figure 9. Capital expenditures for the floating offshore wind reference project 
Table 14. Floating Offshore CapEx and LCOE Breakdown

\begin{tabular}{|c|c|c|}
\hline & $\begin{array}{l}\text { 6.1-MW Floating } \\
\text { Offshore Wind Turbine } \\
\qquad(\$ / k W)\end{array}$ & $\begin{array}{l}\text { 6.1-MW Floating } \\
\text { Offshore Wind Turbine } \\
\text { (\$/MWh) }\end{array}$ \\
\hline TURBINE CAPITAL COST & 1,301 & 22.7 \\
\hline Development cost & 165 & 2.9 \\
\hline Engineering and management & 85 & 1.5 \\
\hline Substructure and foundation & 1,438 & 25.1 \\
\hline Port and staging, logistics, transportation & 44 & 0.8 \\
\hline Electrical infrastructure & 979 & 17.1 \\
\hline Assembly and installation & 439 & 7.7 \\
\hline Lease price & 88 & 1.5 \\
\hline BALANCE OF SYSTEM & 3,237 & 56.6 \\
\hline Insurance during construction & 52 & 0.9 \\
\hline Decommissioning bond & 76 & 1.3 \\
\hline Construction financing & 221 & 3.9 \\
\hline Contingency & 389 & 6.8 \\
\hline Plant commissioning & 52 & 0.9 \\
\hline SOFT COSTS & 790 & 13.8 \\
\hline TOTAL CAPITAL EXPENDITURES & 5,328 & 93.1 \\
\hline
\end{tabular}

Notes:

- The electrical infrastructure cost category includes construction and fabrication costs of both the land-based and offshore substations; this category does not include installation costs for the electrical system, as they are included in the assembly and installation costs.

- Take caution should if comparing fixed-bottom and floating offshore wind project costs because there are significant differences in spatial parameters between the representative sites selected for each technology.

There is a notable difference between the cost components that make up the land-based and offshore projects. In the land-based project, $69 \%$ of the cost is related to the wind turbine. For the offshore project, the turbine makes up $32 \%$ of the fixed-bottom offshore and $24 \%$ of the floating offshore reference project costs. The substructure and foundation portion of the BOS costs is the primary cause for the cost differences between the fixed-bottom and floating offshore projects. The analysis indicates that the fixed-bottom substructure is about $57 \%$ of the cost of the floating substructure (assuming a monopile for fixed bottom and a semisubmersible for floating). The other differences in the BOS and financial costs are related to the empirically-based cost and scaling relationships - some of which are a calculated as a percentage of total costs.

\subsection{Offshore Technology Characteristics and Annual Energy Production}

Offshore wind turbines have increased in size in the recent past and manufacturer announcements suggest that this trend will continue (Shields and Nunemaker 2020). Ten-MW 
turbines are commercially available today, with larger turbines currently in different phases of market and technology development (MHI Vestas 2018). General Electric is testing a prototype 12-MW turbine currently, which is scheduled to be available for commercial deployment in 2021 (GE Renewable Energy 2018). Siemens Gamesa (2020) announced a 2024 target for the commercial release of a 14-MW turbine model, with a power boost feature increasing the capacity to $15 \mathrm{MW}$. Incorporating larger turbines in a project's design may contribute to LCOE reductions via reduced balance-of-plant and O\&M costs (Musial et al. 2017). Larger turbine sizes are made possible in offshore applications, partly because there are fewer transportation and installation limits than for land-based projects.

\subsubsection{Turbine Parameters}

The offshore wind turbine technology characteristics for this analysis are calculated using a capacity-weighted average of the global offshore wind projects installed in 2018. The results of this calculation yield a turbine rating of $6.1 \mathrm{MW}$, rotor diameter of $150.7 \mathrm{~m}$, and a hub height of $101.8 \mathrm{~m}$, as reported in Musial et al. (2019). These values and additional assumptions for the offshore turbine characteristics are summarized in Table 15.

Table 15. Reference Offshore Wind Turbine Parameter Input Assumptions

\begin{tabular}{|l|c|}
\hline \multicolumn{2}{|c|}{ Wind Turbine Parameters } \\
\hline Turbine rated power $(\mathrm{MW})$ & 6.1 \\
\hline Turbine rotor diameter $(\mathrm{m})$ & 150.7 \\
\hline Turbine hub height $(\mathrm{m})$ & 101.8 \\
\hline Drivetrain design & Geared \\
\hline Cut-in wind speed $(\mathrm{m} / \mathrm{s})$ & 3 \\
\hline Cut-out wind speed $(\mathrm{m} / \mathrm{s})$ & 25 \\
\hline
\end{tabular}

\subsubsection{Wind Resource}

In this report, we assessed the wind resource for the fixed-bottom and floating reference sites in the North Atlantic and Pacific Coast, respectively. The details of this analysis and its results are presented in Appendix C. The annual average wind speed in the North Atlantic was assessed to be $8.43 \mathrm{~m} / \mathrm{s}$ at $50 \mathrm{~m}(9.12 \mathrm{~m} / \mathrm{s}$ at a hub height of $101.8 \mathrm{~m})$, and $7.67 \mathrm{~m} / \mathrm{s}$ at $50 \mathrm{~m}(8.30 \mathrm{~m} / \mathrm{s}$ at a hub height of $101.8 \mathrm{~m}$ ) for the Pacific Coast. Note that the same wind resources are used for the 2019 study as were used in 2018. Hub-height wind speeds have been extrapolated from the 2018 hub height of $93.8 \mathrm{~m}$ up to the corresponding 2019 hub height of $101.8 \mathrm{~m}$ using the power law and a wind shear exponent of 0.1 . The wind resource parameters are summarized in Table 16. 
Table 16. Reference Offshore Wind Resource Input Assumptions

\begin{tabular}{|l|c|c|}
\hline \multicolumn{3}{|c|}{ Wind Resource Characteristics } \\
\hline Annual average wind speed at a 50-m height (m/s) & 8.43 & 7.67 \\
\hline $\begin{array}{l}\text { Annual average wind speed at a 101.8-m hub height } \\
\text { (m/s) }\end{array}$ & 9.12 & 8.3 \\
\hline Weibull k & 2.1 & 2.1 \\
\hline Shear exponent & 0.1 & 0.1 \\
\hline
\end{tabular}

\subsubsection{Losses and Availability}

The U.S. offshore reference project considers losses from wind power plant array wake impacts, inefficiencies in power collection and transmission, and losses from wind power plant availability. These losses and availability estimates are determined using ORCA (Beiter et al. 2016), which performs calculations based on a specific wind power plant layout and site-specific meteorological ocean conditions. The total system losses for the fixed-bottom technology in the North Atlantic are 16.0\%, whereas the system losses for the floating offshore technology in the Pacific Coast region are $20.9 \%$. The primary differences in loss between these offshore technologies are the additional electrical cable losses for floating wind in deeper waters (i.e., 34 $\mathrm{m}$ versus $739 \mathrm{~m}$ ), and wake losses from the different reference sites. Table 17 summarizes the losses and availability estimates for the fixed-bottom and floating offshore wind technologies.

Table 17. Reference Offshore Wind Total Losses

\begin{tabular}{|l|c|c|}
\hline & $\begin{array}{c}\text { Losses } \\
\text { North Atlantic } \\
\text { (Fixed Bottom) }\end{array}$ & $\begin{array}{c}\text { Pacific Coast } \\
\text { (Floating) }\end{array}$ \\
\hline Total system losses (\%) & $16.0 \%$ & $20.9 \%$ \\
\hline
\end{tabular}

\subsubsection{Annual Energy Production}

The net AEP is calculated using the wind turbine technology parameters and wind resource inputs, and by applying the appropriate losses and availability estimates. The net AEP is calculated for the offshore reference project for both fixed-bottom and floating offshore applications using ORCA. The resulting net AEP for the fixed-bottom configuration in the North Atlantic is 4,270 MWh/MW/year, with a $48.8 \%$ net capacity factor, and 3,328 MWh/MW/year for the floating configuration in the Pacific Coast region, with a $38.0 \%$ net capacity factor. These values are summarized in Table 18. 
Table 18. Reference Offshore Wind Net Annual Energy Production

\begin{tabular}{|l|c|c|}
\hline \multicolumn{2}{|c|}{ Net Annual Energy Production } \\
\hline & $\begin{array}{c}\text { North Atlantic } \\
\text { (Fixed Bottom) }\end{array}$ & $\begin{array}{c}\text { Pacific Coast } \\
\text { (Floating) }\end{array}$ \\
\hline Net energy capture (MWh/MW/year) & 4,270 & 3,328 \\
\hline Net capacity factor (\%) & $48.8 \%$ & $38.0 \%$ \\
\hline
\end{tabular}

Capacity factors in the United States are expected to vary widely depending on the project location and turbine technology. Improving the performance of offshore wind turbines and arrays has been a continued focus of industry and research activities. More information on the global trends for offshore wind power plant performance can be found in Musial et al. (2017).

\subsection{Offshore Operation and Maintenance Expenditures}

OpEx can vary greatly between projects for a number of reasons; however, the two largest cost drivers are the distance from the project to the maintenance facilities and the meteorological ocean climate at the site (Maples et al. 2013; Pietermen et al. 2011). Beiter et al. (2016) evaluated the O\&M for fixed-bottom and floating substructures located at sites with various wave heights, water depths, and distances from ports informed by parametric studies using the Energy Research Centre of the Netherlands O\&M Tool. ${ }^{19}$ The North Atlantic fixed-bottom and Pacific Coast floating offshore reference projects assume the same operational costs (e.g., annual leases and fees) of $\$ 29 / \mathrm{kW} / \mathrm{yr}$, whereas the maintenance expenditures differ between the two because they each use a different maintenance strategy (i.e., in situ versus tow to shore) and have distinctive site characteristics (i.e., distance from operations port, meteorological ocean conditions, and water depth), resulting in $\$ 124 / \mathrm{kW} / \mathrm{yr}$ for the fixed-bottom project and $\$ 130 / \mathrm{kW} / \mathrm{yr}$ for the floating project. These O\&M costs and the LCOE component breakdown are shown in Table 19.

Table 19. Offshore Wind Reference Project OpEx

\begin{tabular}{|c|c|c|c|c|}
\hline & \multicolumn{2}{|c|}{$\begin{array}{l}\text { North Atlantic } \\
\text { (Fixed Bottom) }\end{array}$} & \multicolumn{2}{|c|}{$\begin{array}{c}\text { Pacific Coast } \\
\text { (Floating) }\end{array}$} \\
\hline & (\$/kW/yr) & $\begin{array}{l}\text { (\$/kilowatt- } \\
\text { hour [kWh]) }\end{array}$ & (\$/kW/yr) & (\$/kWh) \\
\hline Operation & 29 & 6.8 & 28 & 8.5 \\
\hline Maintenance & 95 & 22.2 & 102 & 30.6 \\
\hline OpEx & 124 & 29.0 & 130 & 39.1 \\
\hline
\end{tabular}

\subsection{Offshore Finance}

This section describes the financing assumptions for the report's representative offshore wind (both fixed bottom and floating) reference projects in the United States in 2018. In this report, the offshore financing assumptions are consistent with NREL's 2019 ATB (Feldman et. al. 2020). A comparison to the financing terms (including the impact on LCOE) used in the "2018 Cost of Wind Energy Review: is shown in Appendix B. Financing terms are intended to

\footnotetext{
${ }^{19}$ Operation and maintenance costs for offshore wind projects are assumed to include labor, vessels, equipment, scheduled maintenance, unscheduled maintenance, land-based support, and administration.
} 
represent a commercial-scale power plant and are assumed the same for fixed-bottom and floating technology for simplicity.

\subsubsection{Discount Rate}

An individual project's financing terms reflect its specific risk profile, assumptions, and ranges of nominal discount rates for offshore wind. The generic assumptions used for this report are consistent with NREL's 2019 ATB (Feldman et al. 2020), which were derived from industry interviews and a literature review. For this analysis, we assumed the discount rate and other economic evaluation metrics to be similar for the North Atlantic and Pacific Coast representative projects. The updated nominal WACC for 2019 is 5.29\%, which corresponds to a real WACC of $2.72 \%$, assuming a $2.5 \%$ inflation rate. ${ }^{20}$ Underlying assumptions for marginal tax rate and inflation are consistent with those presented in Section 4.5.1.

\subsubsection{Economic Evaluation Metrics}

To determine the LCOE for the 2019 representative offshore wind projects, a similar FCR methodology that was used for the land-based representative wind project is applied (see Section 4.5) and informed by the 2020 ATB. The FCR includes the present value of the accumulated depreciation benefit and ignores bonus depreciation. Assuming a project life of 25 years and discount rates and depreciation benefits as calculated, the offshore reference project nominal and real FCR for fixed-bottom and floating technologies is $7.64 \%$ and $5.82 \%$, respectively. Table 20 presents a summary of nominal and real WACC, CRF, and FCR that is used throughout the offshore analysis.

Table 20. Summary of Offshore Reference Project Economic Evaluation Metrics

\begin{tabular}{|lcc|} 
& $\begin{array}{c}\text { North Atlantic and Pacific Coast } \\
\text { (Fixed Bottom and Floating) } \\
\text { Nominal }\end{array}$ & $\begin{array}{c}\text { Real } \\
\text { NACC (\%) }\end{array}$ \\
\hline CRF (\%) & $7.29 \%$ & $2.72 \%$ \\
\hline FCR (\%) & $7.30 \%$ & $5.60 \%$ \\
\hline
\end{tabular}

\subsection{Offshore Reference Project Levelized Cost of Energy}

Based on the offshore wind turbine technology parameters, site conditions, wind resource, and cost estimates, we used the CapEx, FCR, OpEx, and AEP to calculate LCOE for the 2019 offshore reference wind power plant for fixed-bottom and floating technologies. LCOE for the fixed-bottom North Atlantic representative project is calculated at $\$ 85 / \mathrm{MWh}$ and $\$ 132 / \mathrm{MWh}$ for the representative floating project on the Pacific Coast. Table 21 summarizes the fixed-bottom costs for the primary components (including their contribution to LCOE) in the North Atlantic. The graphic in Figure 10 illustrates the LCOE breakdown for the primary components of the North Atlantic wind power plant, whereas Figure 11 provides a graphical representation of

\footnotetext{
${ }^{20}$ See Appendix B for a comparison to the financing terms (including the impact on LCOE) used in the " 2018 Cost of Energy Review."
} 
LCOE by line item. Table 22, Figure 12, and Figure 13 show the cost values, LCOE breakdown, and the LCOE values for the floating project in the Pacific Coast region.

\section{Table 21. Fixed-Bottom Offshore Wind LCOE and Reference Projects Cost Breakdown}

\begin{tabular}{|c|c|c|}
\hline & $\begin{array}{l}\text { 6.1-MW Fixed-Bottom } \\
\text { Offshore Wind Turbine } \\
\qquad(\$ / k W)\end{array}$ & $\begin{array}{l}\text { 6.1-MW Fixed-Bottom } \\
\text { Offshore Wind Turbine } \\
\text { (\$/MWh) }\end{array}$ \\
\hline Turbine capital cost & 1,301 & 17.7 \\
\hline Balance of system & 2,131 & 29.0 \\
\hline Financial costs & 645 & 8.8 \\
\hline CapEx & 4,077 & 55.6 \\
\hline OpEx (\$/kW/yr) & 124 & 29.0 \\
\hline Fixed charge rate (real) [\%] & \multicolumn{2}{|c|}{$5.8 \%$} \\
\hline Net annual energy production (MWh/MW/yr) & \multicolumn{2}{|c|}{4,270} \\
\hline Net capacity factor (\%) & \multicolumn{2}{|c|}{$48.7 \%$} \\
\hline Total LCOE (\$/MWh) & \multicolumn{2}{|c|}{85} \\
\hline
\end{tabular}

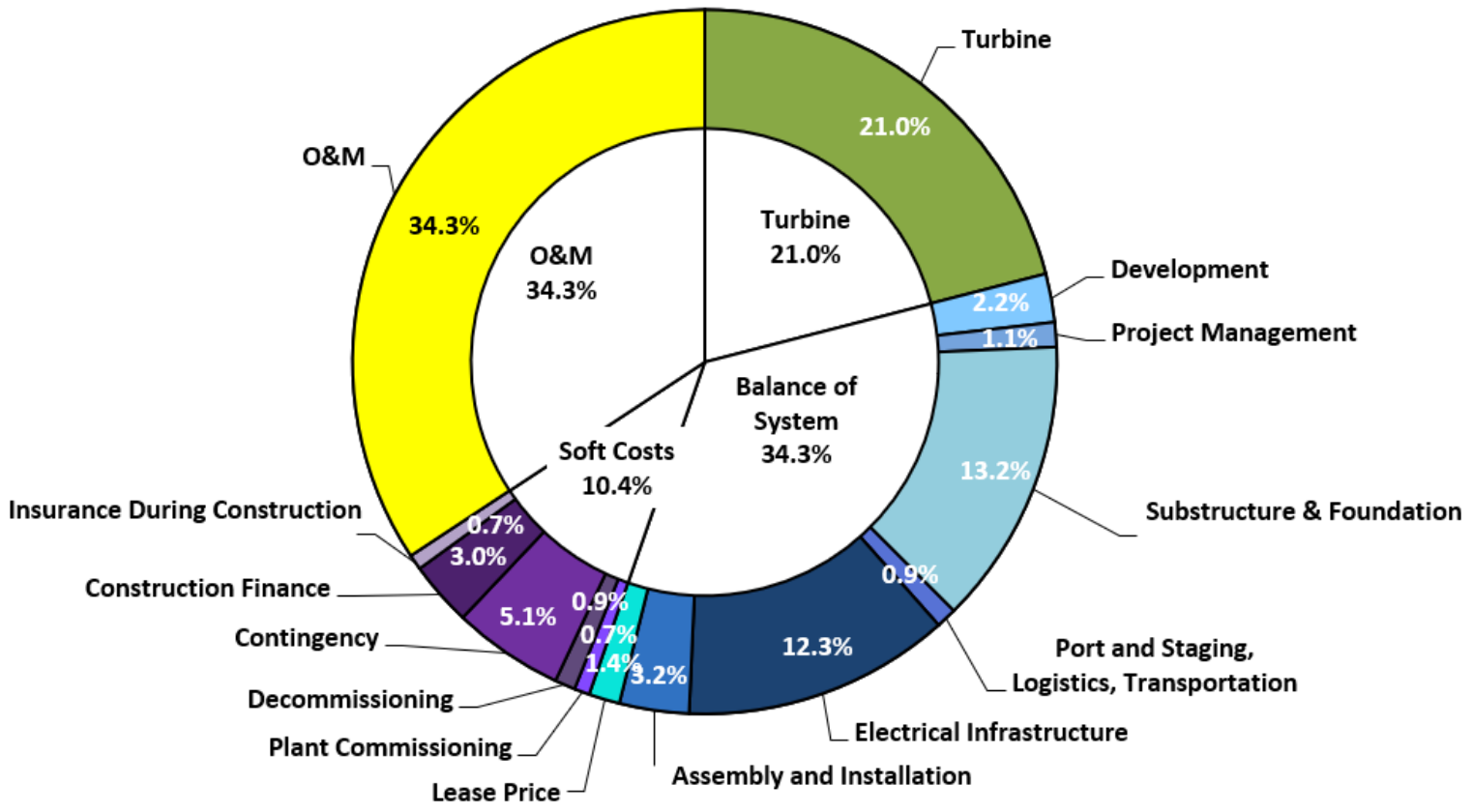

Figure 10. Component-level LCOE contribution for the 2019 fixed-bottom offshore wind reference project operating for 25 years 


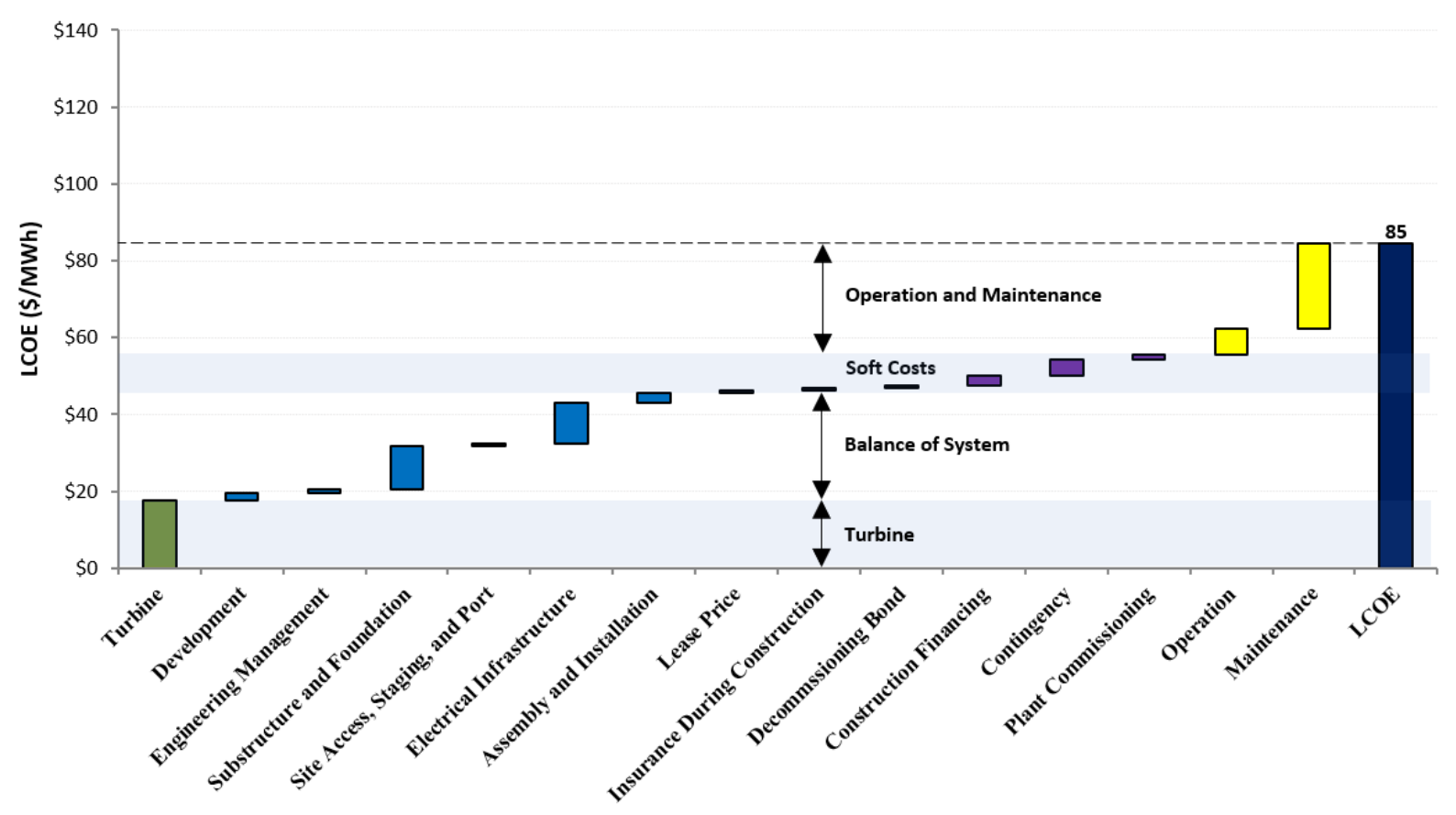

Figure 11. Component-level cost breakdown for the 2019 fixed-bottom offshore wind reference project

Table 22. Floating Offshore Wind LCOE and Reference Projects Cost Breakdown

\begin{tabular}{|c|c|c|}
\hline & $\begin{array}{l}\text { 6.1-MW Floating } \\
\text { Offshore Wind Turbine } \\
\qquad(\$ / \mathrm{kW})\end{array}$ & $\begin{array}{l}\text { 6.1-MW Floating } \\
\text { Offshore Wind Turbine } \\
\text { (\$/MWh) }\end{array}$ \\
\hline Turbine capital cost & 1,301 & 22.7 \\
\hline Balance of system & 3,237 & 56.6 \\
\hline Financial costs & 790 & 13.8 \\
\hline CapEx & 5,328 & 93.1 \\
\hline OpEx (\$/kW/yr) & 130 & 39.2 \\
\hline Fixed charge rate (real) [\%] & \multicolumn{2}{|c|}{$5.8 \%$} \\
\hline Net annual energy production (MWh/MW/yr) & \multicolumn{2}{|c|}{3,328} \\
\hline Net capacity factor (\%) & \multicolumn{2}{|c|}{$38.0 \%$} \\
\hline Total LCOE (\$/MWh) & \multicolumn{2}{|c|}{132} \\
\hline
\end{tabular}




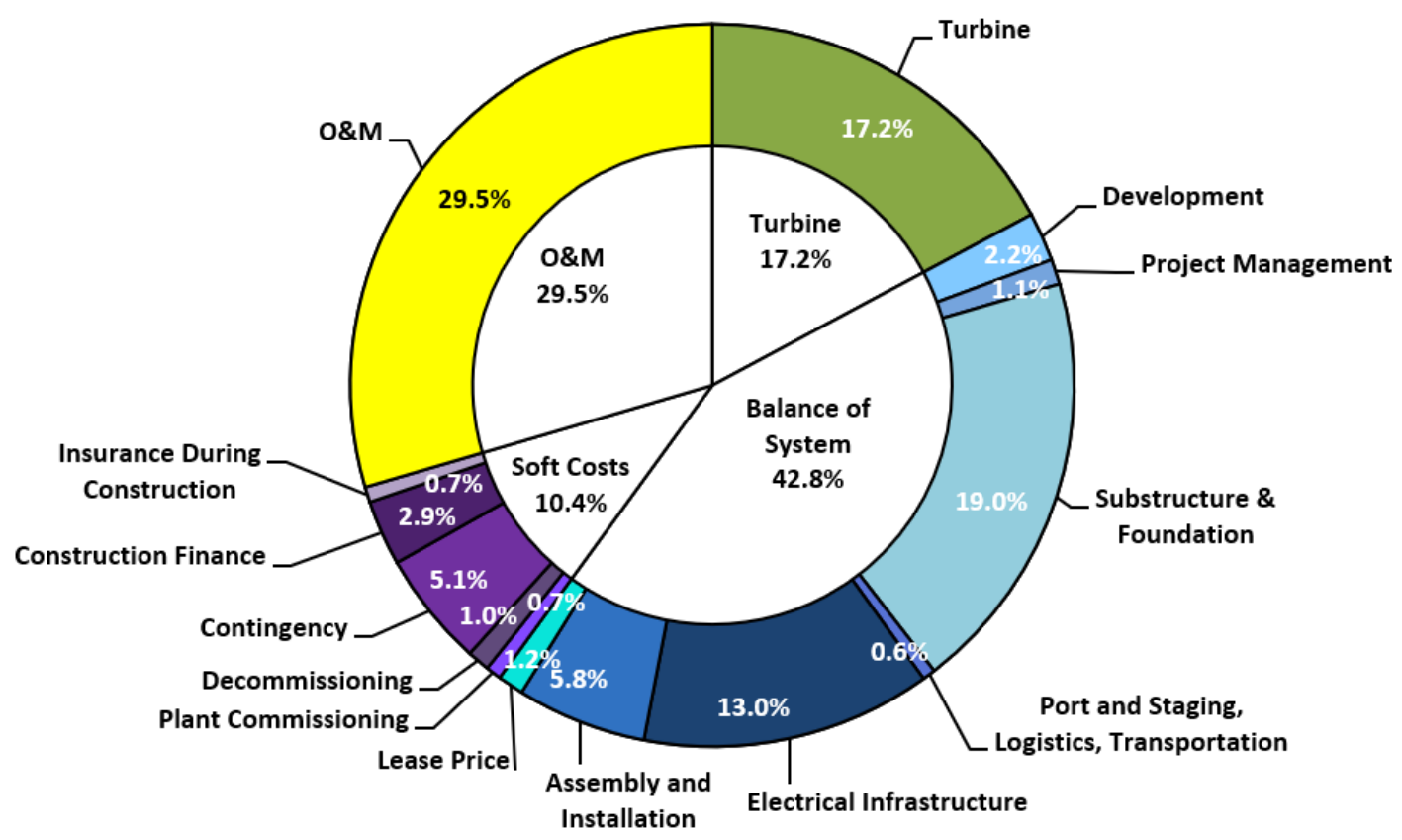

Figure 12. Component-level LCOE contribution for the 2019 floating offshore wind reference project operating for 25 years

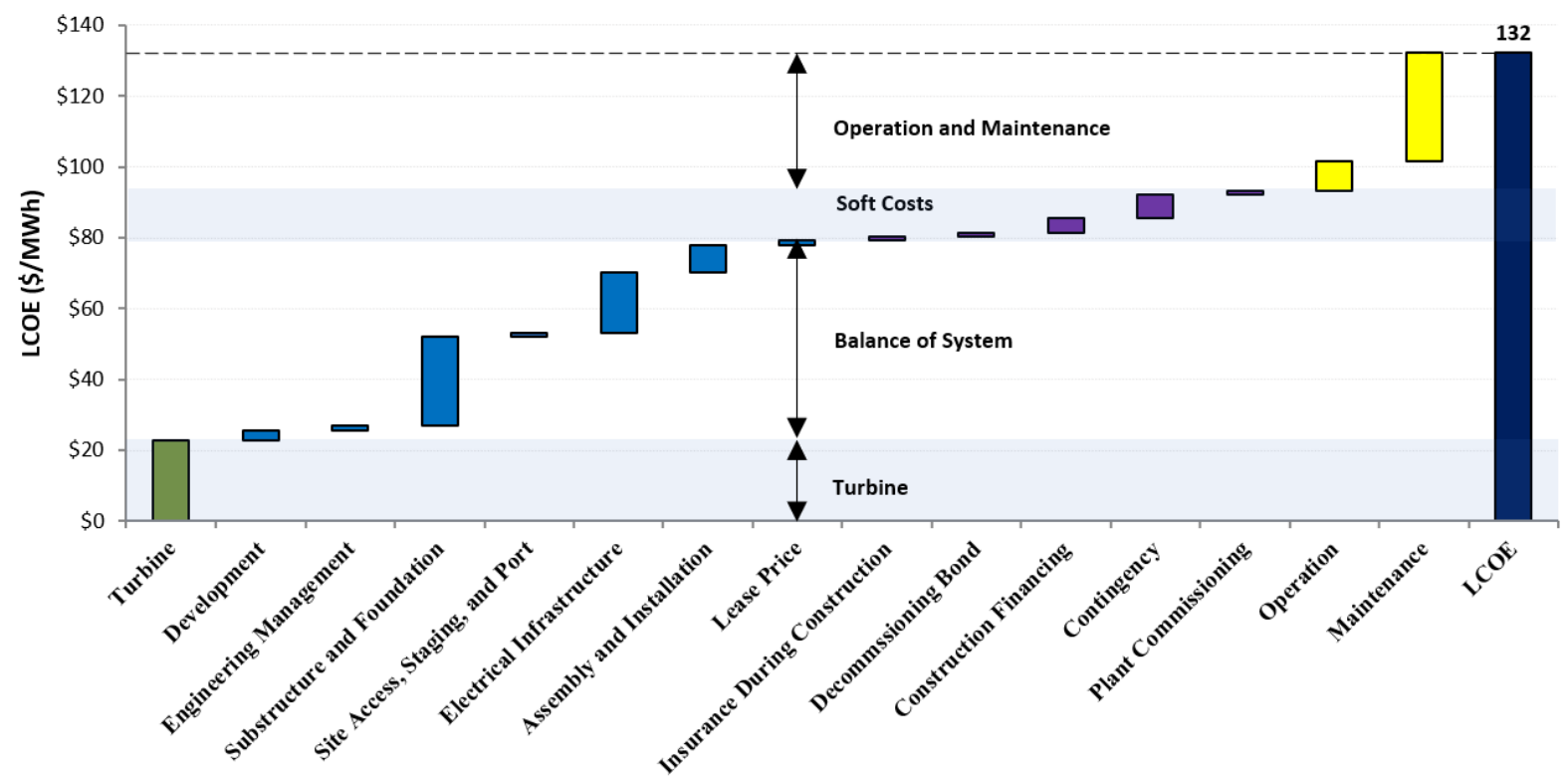

Figure 13. Component-level cost breakdown for the 2019 floating offshore wind reference project

\subsection{Offshore Levelized Cost of Energy Sensitivities}

The LCOE parameters described earlier represent the fixed-bottom and floating offshore reference wind projects; however, input parameters for a near-term wind project are subject to considerable uncertainty. Hence, it is beneficial to investigate how this variability may impact the LCOE. The sensitivity analysis shown in Figure 14 (for the North Atlantic fixed-bottom site) 
and Figure 15 (for the Pacific Coast floating site) focuses on the basic LCOE inputs: CapEx, OpEx, net capacity factor, and FCR, which are broken into two principal elements - discount rate and economic operational lifetime. We determined the sensitivity ranges for the LCOE inputs by examining the globally installed offshore projects in 2019 reported in the "2019 Offshore Wind Technology Data Update" (Musial et al. 2020) and NREL's offshore wind database.

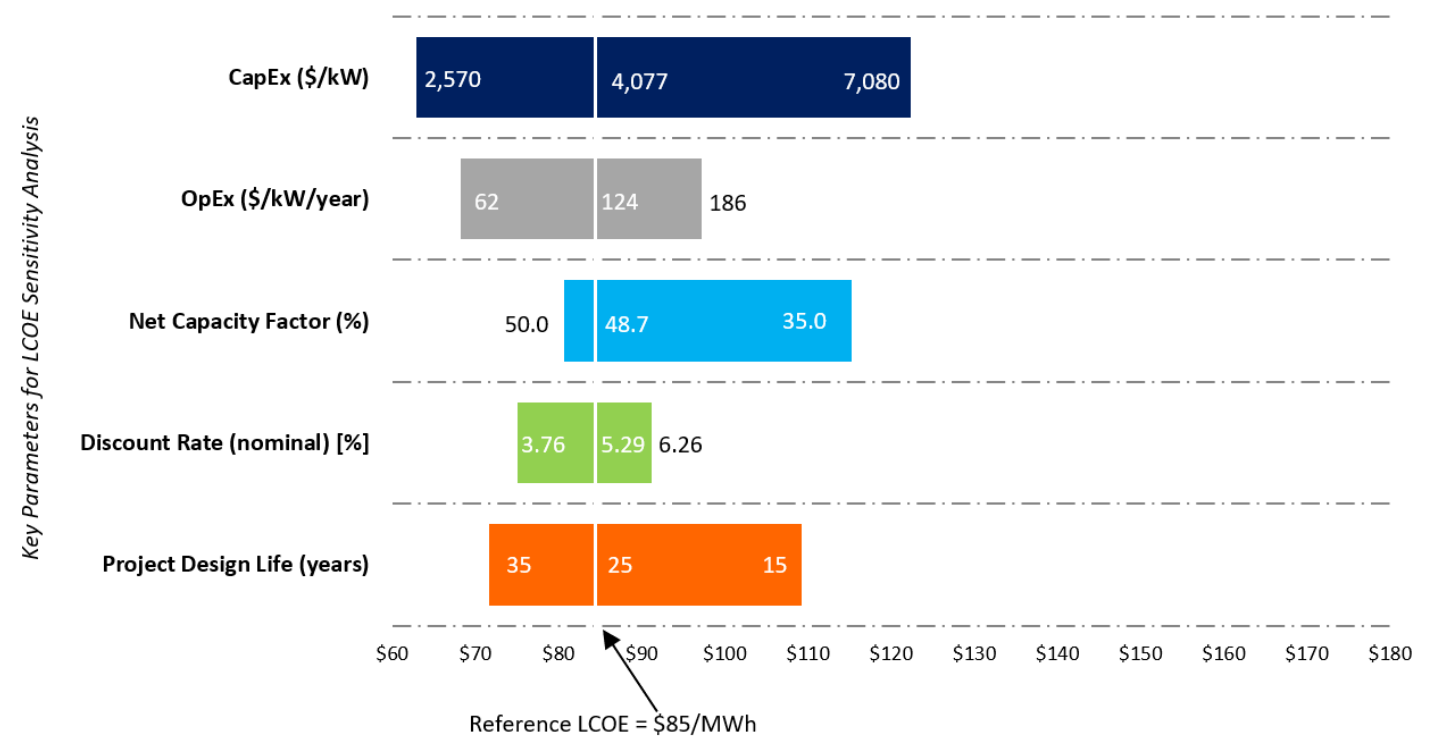

Figure 14. Sensitivity of fixed-bottom offshore wind LCOE to key input parameters

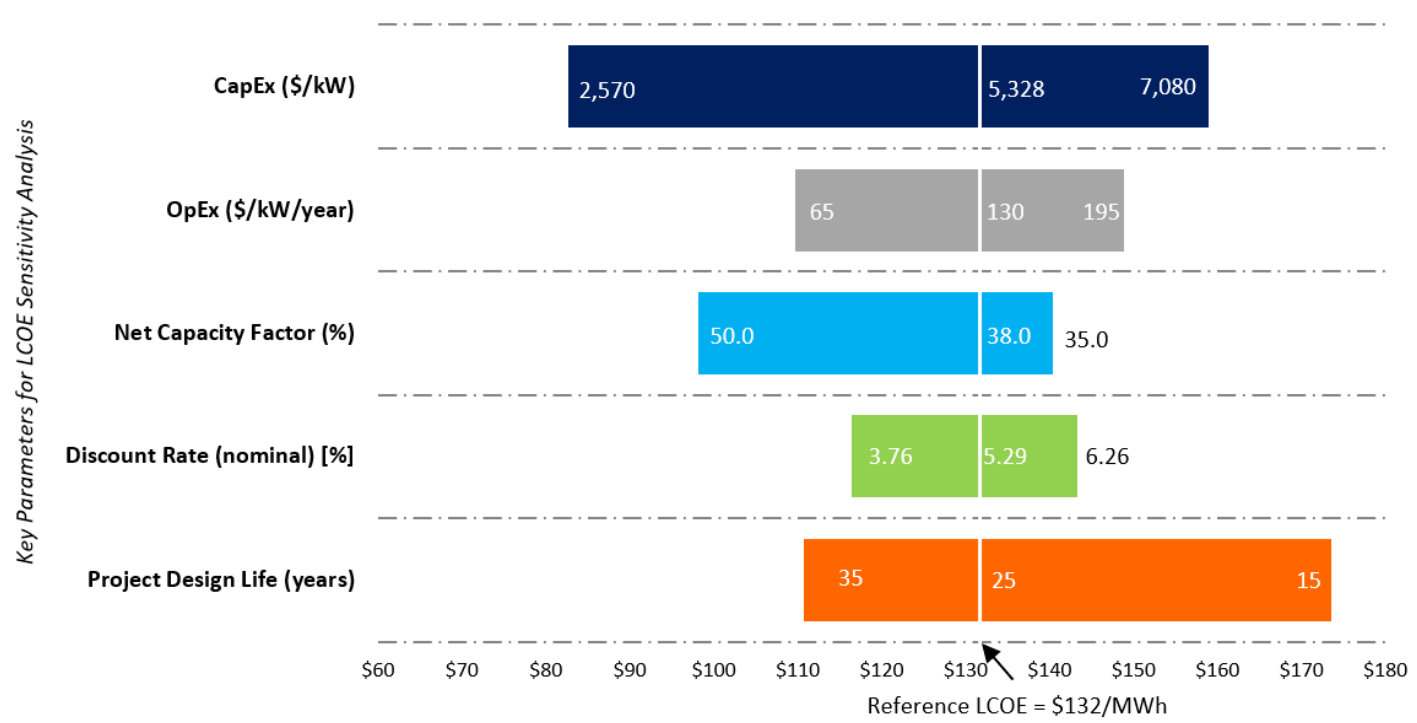

Figure 15. Sensitivity of floating offshore wind LCOE to key input parameters

Note: The reference LCOE reflects a representative industry LCOE. Changes in LCOE for a single variable can be understood by moving to the left or right along a specific variable. Values on the x-axis indicate how the LCOE will change as a given variable is altered and all others are assumed constant (i.e., remain reflective of the reference project). 
Sensitivity analyses are conducted by holding all reference project assumptions constant and altering only the variable in question. Sensitivity ranges are selected to represent the highs and lows observed in the industry and from the data in the "2019 Offshore Wind Technology Data Update" (Musial et. al. 2020). This selection of ranges provides insight into how real-world ranges influence LCOE. Keeping the same 600-MW project size, the sensitivity analysis yields ranges in LCOE from a low of $\$ 63 / \mathrm{MWh}$ to a high of $\$ 122 / \mathrm{MWh}$ for fixed-bottom configurations (Figure 14), and a low of $\$ 83 / \mathrm{MWh}$ to a high of $\$ 174 / \mathrm{MWh}$ for floating configurations (Figure 15). Within the ranges shown, CapEx and project design life are the two factors that are shown to have the greatest impact on offshore wind LCOE, with CapEx having the greatest influence on decreasing LCOE relative to the reference projects.

\subsection{Offshore Wind Supply Curve}

Nearly 5,500 GW of offshore wind gross resource potential has been estimated for the "2019 Cost of Energy Review" covering the continental United States (excluding Alaska and Hawaii). This gross resource potential does not exclude any areas of competing use or exclusion areas ${ }^{21}$ and was calculated using a geographic-information-system-based algorithm documented in Beiter et al. (2017). For the offshore wind supply curve, the LCOE for each of the potential wind power plant locations is computed using a site-specific CapEx, OpEx, and net AEP. LCOE varies by offshore geographic region primarily because of the available wind resource, distance from port, and water depth. Incremental costs associated with labor rates, material costs, logistical or siting challenges, and distance to existing transmission infrastructure also contribute to regional differences.

LCOE, which includes the cost of transmission and was calculated for this gross resource area, ranged from $\$ 72 / \mathrm{MWh}$ to $\$ 252 / \mathrm{MWh}$. Figure 16 illustrates the supply curve of the gross offshore wind resource potential and highlights the 2019 fixed-bottom (marked with an orange diamond) and floating (marked with a blue diamond) offshore wind reference sites.

${ }^{21}$ This gross resource potential compares to nearly 2,060 GW of "technical resource capacity" when considering various competing use and exclusion areas (Musial et al. 2016). 


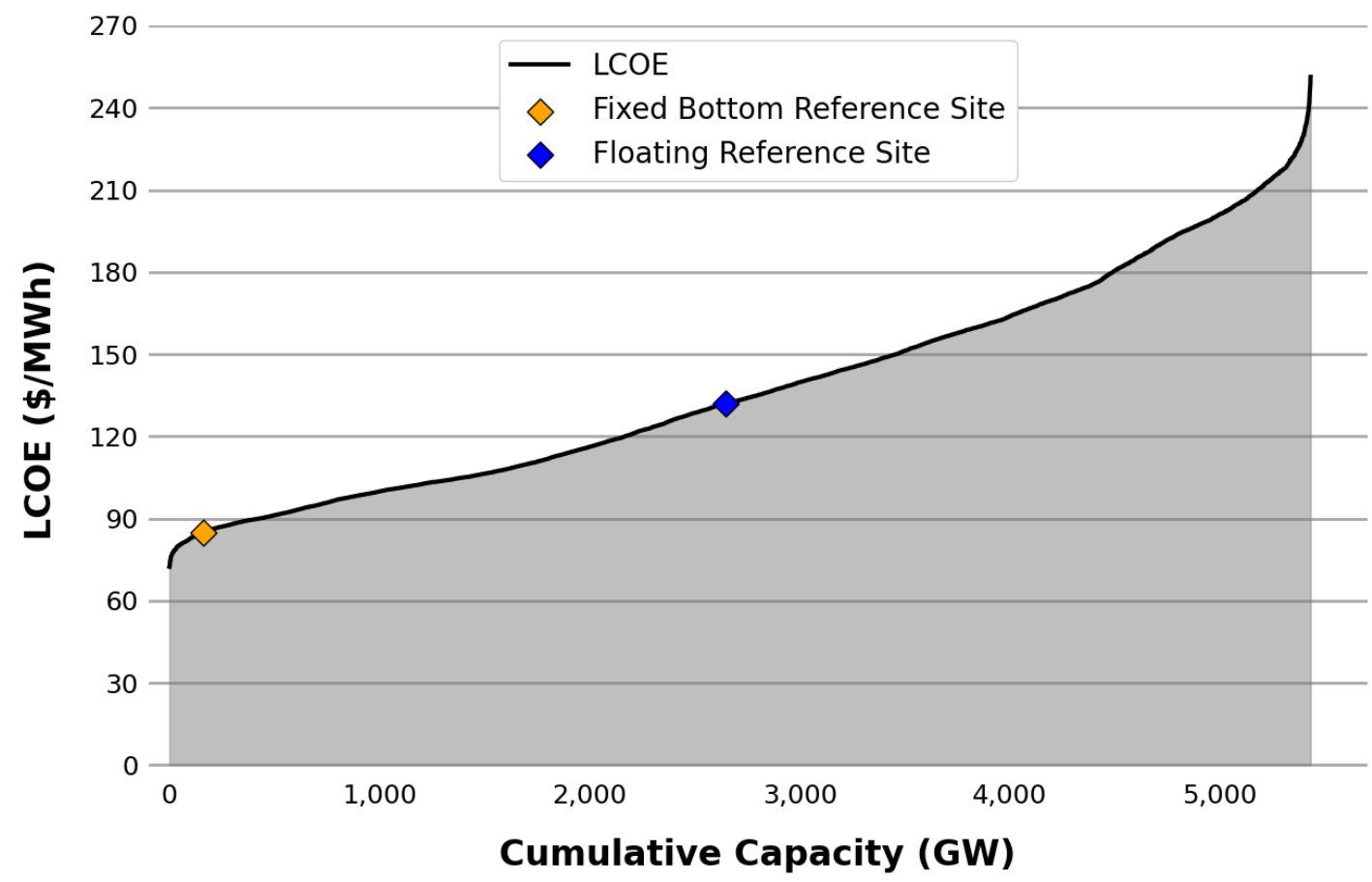

Figure 16. National fixed-bottom and floating offshore wind supply curve

\subsection{Offshore Discussion of Results in Context of DOE Goals}

In this section, we present the fixed-bottom offshore wind GPRA levelized cost of energy 2030 target. The 2030 target analysis estimates the future CapEx and O\&M costs using ORCA (Beiter et al. 2016) and assuming a wind power plant comprising 15-MW wind turbines placed in the North Atlantic reference site. The cost reduction trajectory is also informed by technology innovations considered in the spatial economic analysis by Beiter et al. (2016). This future technology assessment estimates the wind power plant's CapEx to be $\$ 3,476 / \mathrm{kW}$, with an O\&M cost of $\$ 60 / \mathrm{kW} / \mathrm{yr}$ operating at a $58 \%$ net capacity factor. The future financial assumptions are informed by NREL's 2019 ATB, with an operation life of 25 years for a $5.7 \%$ real FCR. The $2030 \mathrm{LCOE}$ calculated from this analysis is $\$ 51 / \mathrm{MWh}$ and is designated as the $2030 \mathrm{GPRA}$ target. The GRPA targets for 2019 through 2030 are shown in Figure 17. The reported LCOE value for 2019 is calculated in this report (Section 5.6) and labeled as "Historically Reported Data" in Figure 17. 


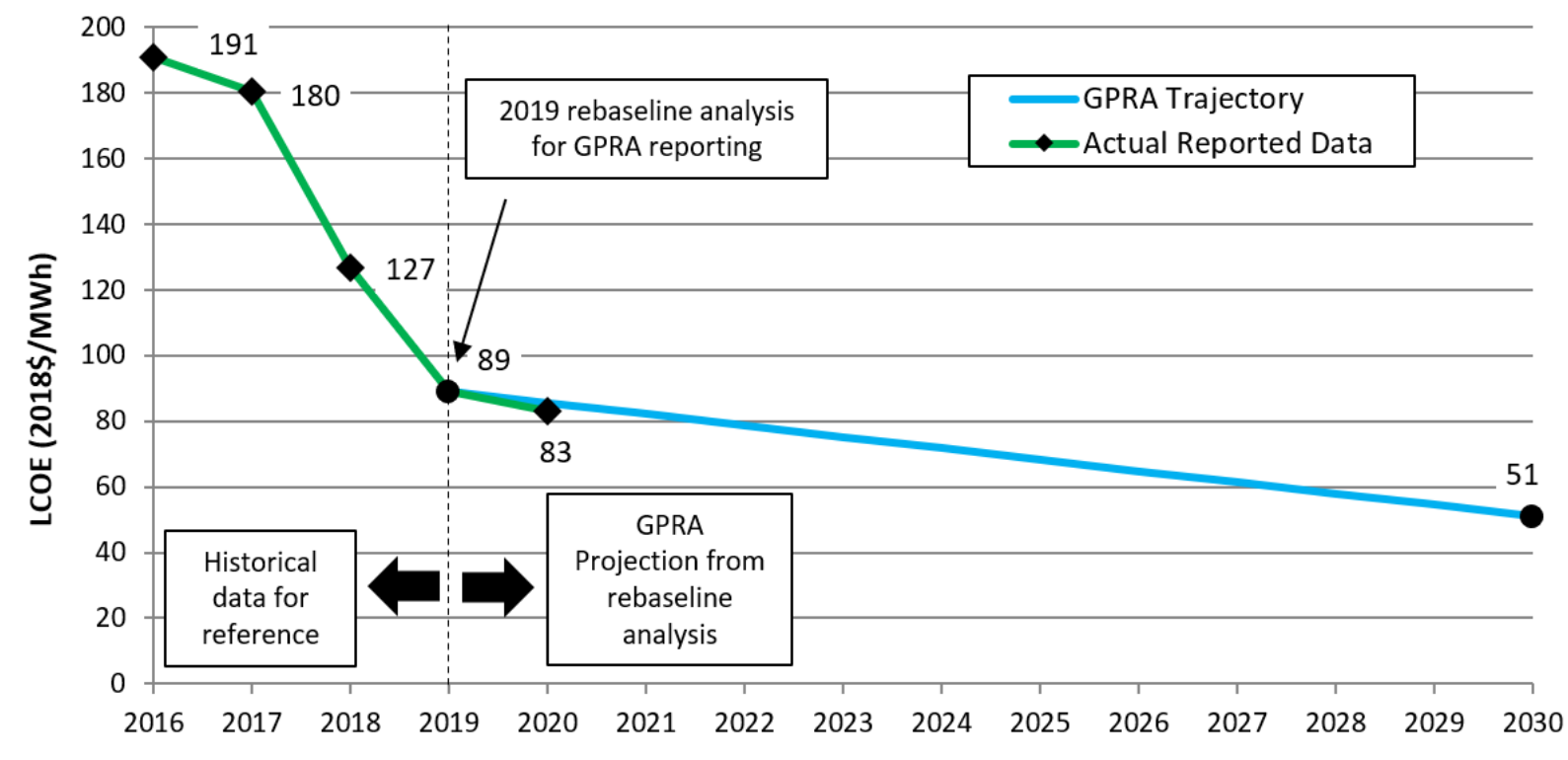

Figure 17. Fixed-bottom wind GPRA cost trajectories for LCOE

The reduction in the estimated LCOE ("GPRA goal") between 2019 and 2030 is categorized as various cost components: O\&M expenditures $(\$ 17 / \mathrm{MWh})$, CapEx components (i.e., turbine, electric system, and support structure; \$12/MWh), and improvements in AEP (\$9/MWh). These categories and their respective cost reductions are shown in Figure 18.

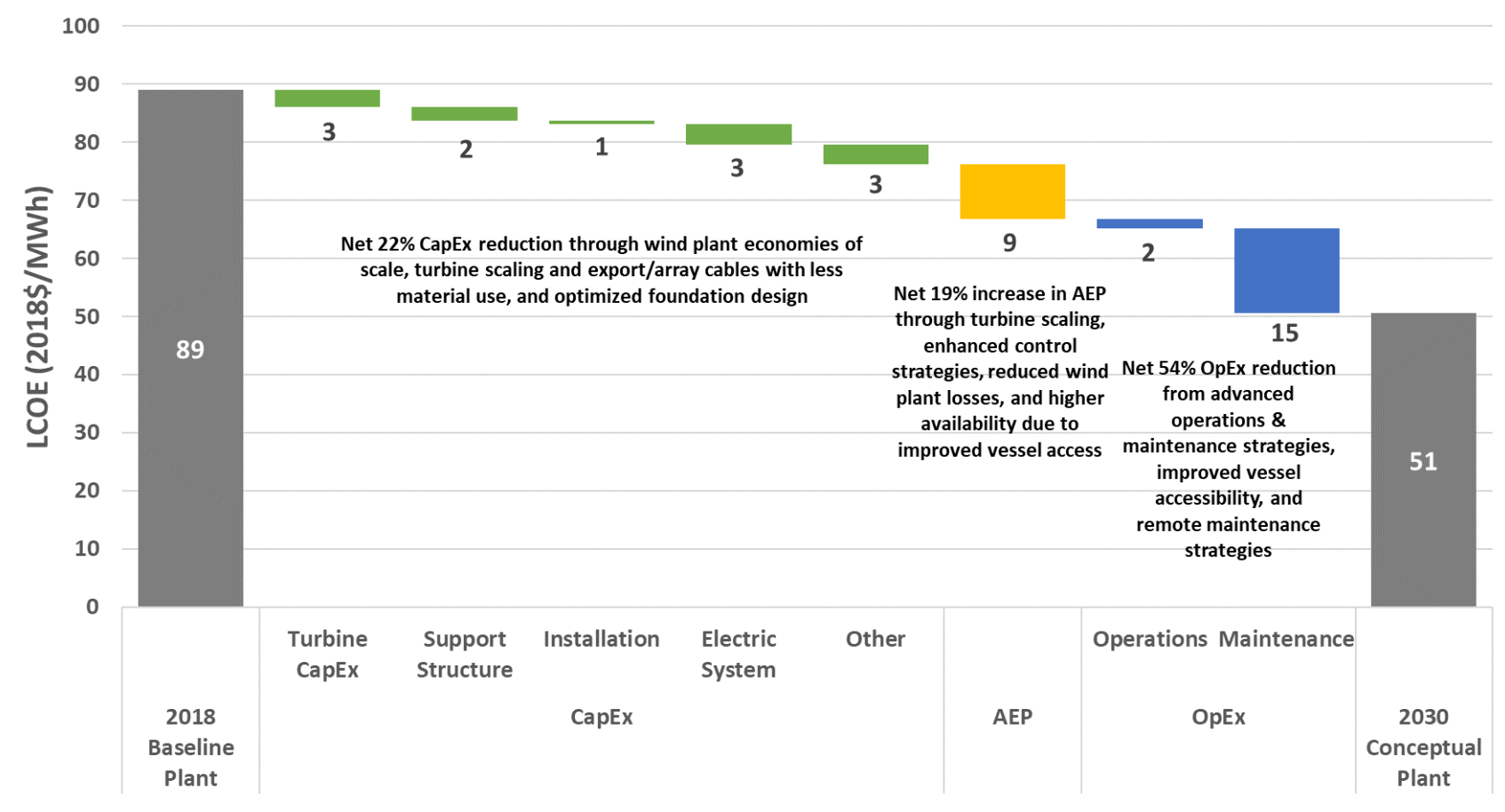

Figure 18. Fixed-bottom cost reductions in GPRA cost trajectories for LCOE 


\section{Distributed Wind}

\subsection{Distributed Wind Reference Projects}

The distributed wind reference projects are intended to represent wind sites suitable for residential and commercial-scale turbines found in the United States. The wind turbine sizes for the residential and commercial scale projects are $20 \mathrm{~kW}$ and $100 \mathrm{~kW}$, respectively. The representative project size for the residential and commercial comprise a single turbine installation. These reference project parameters are summarized in Table 23. Further detail on the turbine parameters are summarized in Table 25. The turbines are assumed to be operating for 25 years with no catastrophic O\&M events.

Table 23. Distributed Wind Reference Projects Parameters

\begin{tabular}{|lc|c|}
\hline Parameters & Residential $(\mathbf{2 0} \mathbf{~ k W})$ & Commercial $(\mathbf{1 0 0} \mathbf{k W})$ \\
\hline Turbine rated power $(\mathrm{kW})$ & 20 & 100 \\
\hline Number of turbines & 1 & 1 \\
\hline Wind project capacity $(\mathrm{kW})$ & 20 & 100 \\
\hline Project design life (years) & 25 & 25 \\
\hline
\end{tabular}

Note: Project design life refers to the time in which the wind power plant is expected to operate (not referring to the turbine's design life for engineering or certification purposes).

\subsection{Distributed Wind Capital Expenditures}

The CapEx data for distributed wind projects in the United States tend to be limited, hence, the total system CapEx for the representative distributed wind projects is composed using empirical data sets and complemented by bottom-up cost models. In this report, the turbine CapEx data are sourced from the annual published data by DOE (Orrell et. al. 2020), whereas, the balance-ofsystem CapEx is estimated using NREL's LandBOSSE model (Eberle et. al. 2019). Overall, the model is based on a bottom-up assessment of inputs and outputs associated with each BOS operation and, where needed, is supplemented by top-down estimates of costs from industry. Figure 19 illustrates the breakdown of CapEx for the 20-kW residential and 100-kW commercial projects. A majority of the residential project's CapEx is contributed by the BOSapproximately 55\% of the total CapEx. Comparatively, the commercial project is weighted heavier on the cost of the turbine - about 59\% of the total CapEx. Because CapEx data are scarce for the residential and commercial projects, further cost details on the individual system components are not presented in this report. 

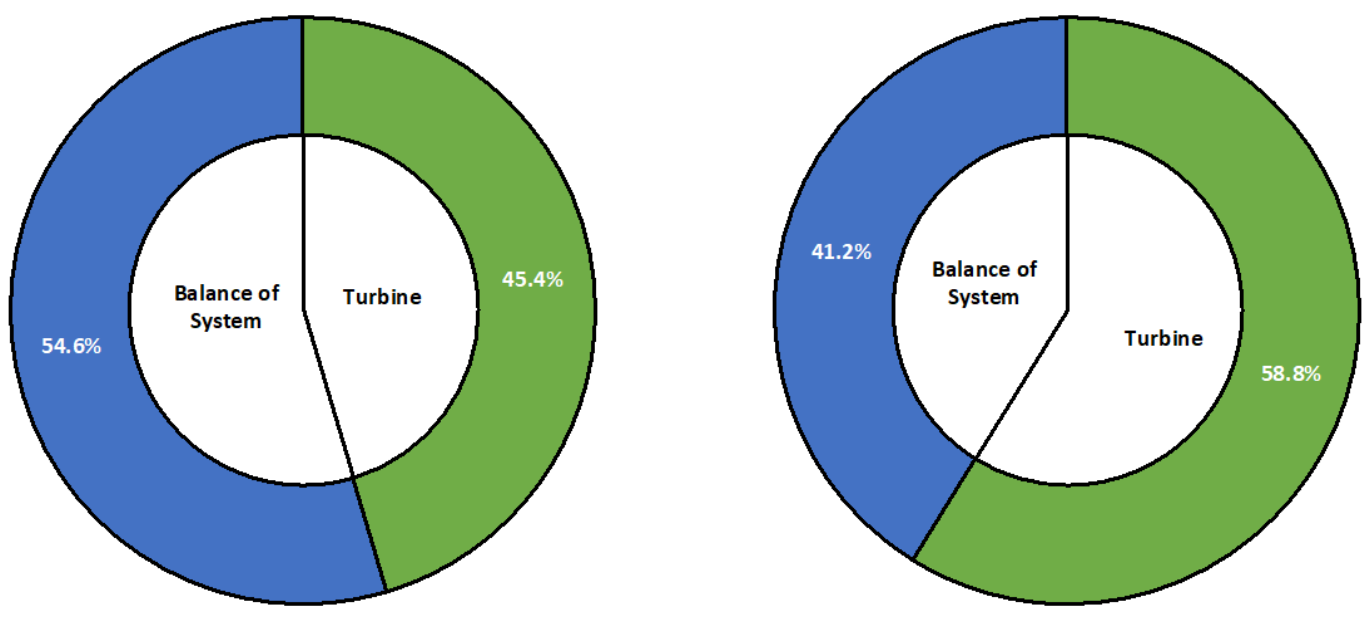

Figure 19. CapEx for the residential (left) and commercial (right) reference wind projects

Table 24 summarizes the costs for the reference projects wind turbine and BOS CapEx components (including their contribution to LCOE). We estimated the total installed project CapEx for the representative residential and commercial distributed wind projects to be $\$ 5,675 / \mathrm{kW}$ and $\$ 4,300 / \mathrm{kW}$, respectively. More details on the representative wind projects energy production and financial assumptions used to calculate the LCOE are provided in Section 6.3 and Section 6.5, respectively.

Table 24. Distributed Wind CapEx and LCOE Breakdown

\begin{tabular}{|c|c|c|c|c|}
\hline \multirow{2}{*}{ Category } & \multicolumn{2}{|c|}{ Residential $(\mathbf{2 0} \mathbf{k W})$} & \multicolumn{2}{c|}{ Commercial (100 kW) } \\
& $(\$ / \mathbf{k W})$ & $(\$ / M W h)$ & $(\$ / \mathbf{k W})$ & (\$/MWh) \\
\hline Turbine capital cost & 2,575 & 65.9 & 2,530 & 53.7 \\
\hline Balance of system & 3,100 & 79.4 & 1,770 & 37.6 \\
\hline Total capital expenditures & $\mathbf{5 , 6 7 5}$ & 145.3 & 4,300 & 91.2 \\
\hline
\end{tabular}

\subsection{Distributed Wind Technology Characteristics and Annual Energy Production}

\subsubsection{Turbine Parameters}

For the purpose of this report, the turbine parameters are specific to the turbine and independent of the wind resource characteristics. We developed the power curve for the $20-\mathrm{kW}$ residential system and the 100-kW commercial system assuming stall-regulated turbines with standard air density. ${ }^{22}$ A summary of the distributed wind turbine parameters is shown in Table 25.

\footnotetext{
${ }^{22}$ The authors used a standard air density of $1.225 \mathrm{~kg} / \mathrm{m}^{3}$ for power curve development.
} 
Table 25. Reference Distributed Wind Turbine Parameters

\begin{tabular}{|lc|c|}
\hline Parameter & Residential (20 kW) & Commercial (100kW) \\
\hline Turbine rated power $(\mathrm{MW})$ & 20 & 100 \\
\hline Turbine rotor diameter $(\mathrm{m})$ & 12.4 & 27.6 \\
\hline Turbine hub height $(\mathrm{m})$ & 30 & 40 \\
\hline Cut-in wind speed $(\mathrm{m} / \mathrm{s})$ & 3 & 3 \\
\hline Cut-out wind speed $(\mathrm{m} / \mathrm{s})$ & 20 & 25 \\
\hline Maximum coefficient of power & 0.39 & 0.39 \\
\hline
\end{tabular}

\subsubsection{Wind Resource}

The average wind speed can vary from project to project across the United States. The annual average wind speed chosen for both the residential and commercial reference projects is $6 \mathrm{~m} / \mathrm{s}$ at $50 \mathrm{~m}$ above ground level $(5.58 \mathrm{~m} / \mathrm{s}$ at the $20-\mathrm{kW}$ wind turbine hub height of the $30-\mathrm{m}$ project and $5.81 \mathrm{~m} / \mathrm{s}$ at $40 \mathrm{~m}$ for the $100-\mathrm{kW}$ wind turbine). This wind speed is intended to be generally indicative of the wind regime for distributed wind projects installed in moderate-quality sites. A summary of the wind resource assumptions for the 2019 representative site is included in Table 26.

Table 26. Reference Residential and Commercial Distributed Wind Resource Assumptions

\begin{tabular}{|lc|}
\hline \multicolumn{2}{|c|}{ Wind Resource Characteristics } \\
\hline Annual average wind speed at a 50-m height $(\mathrm{m} / \mathrm{s})$ & 6 \\
\hline Annual average wind speed at a 30-m hub height $(\mathrm{m} / \mathrm{s})$ - residential & 5.58 \\
\hline Annual average wind speed at a 40-m hub height $(\mathrm{m} / \mathrm{s})$ - commercial & 5.81 \\
\hline Weibull k & 2.0 \\
\hline Shear exponent & 0.14 \\
\hline
\end{tabular}

\subsubsection{Losses and Availability}

Although some losses can be affected by turbine design or wind resource characteristics, they are treated as independent of any other input in this simplified analysis. Types of losses accounted for here include blade soiling, turbine controls, and grid availability, totaling $11.5 \%$. The wind turbine availability is assumed to be $95 \%$, indicating that the wind project is ready to produce power between wind turbine cut-in and cut-out wind speeds $95 \%$ of the time. Net average AEP is calculated by applying all losses and availability to the gross AEP. Table 27 shows the estimated losses and availability for the residential and commercial reference wind projects.

Table 27. Reference Residential and Commercial Distributed Wind Project Losses and Availability Assumptions

\begin{tabular}{|lc|}
\hline \multicolumn{2}{|c|}{ Losses } \\
\hline Losses (i.e., blade soiling, turbine controls, grid availability) & $11.5 \%$ \\
\hline Availability & $95 \%$ \\
\hline
\end{tabular}




\subsubsection{Annual Energy Production}

We estimated the gross AEP for this analysis using generic power curves for the 20- and 100-kW turbines developed by NREL and computed in Openwind (UL undated). The software uses the residential and commercial wind turbine power curves, reference wind resource, and standard air density to compute the annual energy capture for the wind projects. The losses and availability are then applied to calculate the net AEP. The result of these calculations yields a net energy capture of 2,580 kWh/kW/year, which corresponds to a $29.5 \%$ net capacity factor assuming 8,760 hours in a year for the residential project and $2,846 \mathrm{kWh} / \mathrm{kW} /$ year $-32.5 \%$ net capacity factor for the commercial project. The net energy capture and net capacity factor for the reference wind projects are shown in Table 28.

Table 28. Reference Residential and Commercial Distributed Wind Projects AEP and Capacity Factor Summary

\begin{tabular}{|lc|c|}
\hline \multicolumn{3}{|c|}{ AEP and Capacity Factors (6-m/s wind speed at $50 \mathrm{~m})$} \\
& Residential $(20 \mathrm{~kW})$ & Commercial (100 kW) \\
\hline Net energy capture (kWh/kW/yr) & 2,580 & 2,846 \\
\hline Net capacity factor $(\%)$ & $29.5 \%$ & $32.5 \%$ \\
\hline
\end{tabular}

\subsection{Distributed Wind Operation and Maintenance Expenditures}

For the distributed wind analysis, all operation and maintenance costs are combined to a single term expressed as dollars per kilowatt per year $(\$ / \mathrm{kW} / \mathrm{yr})$. O\&M market data are not widely available for distributed wind projects; therefore, $\$ 35 / \mathrm{kW} / \mathrm{yr}$ are assumed - reported in "Assessing the Future of Distributed Wind" (Lantz et al. 2016) -for both residential and commercial distributed wind projects. ${ }^{23}$ The annual O\&M cost from the 2016 report and the LCOE contributions for the representative wind projects are shown in Table 29.

Table 29. Distributed Wind Reference Projects OpEx

\begin{tabular}{|l|c|c|c|c|}
\hline & \multicolumn{2}{|c|}{ Residential $(20 \mathrm{~kW})$} & \multicolumn{2}{c|}{ Commercial $(100 \mathrm{~kW})$} \\
& $\$ / \mathrm{kW} / \mathrm{yr}$ & $\$ / \mathrm{MWh}$ & $\$ / \mathrm{kW} / \mathrm{yr}$ & $\$ / \mathrm{MWh}$ \\
\hline OpEx & 35 & 13.6 & 35 & 12.3 \\
\hline
\end{tabular}

\subsection{Distributed Wind Finance}

This section describes the financing assumptions for the report's representative residential and commercial distributed wind reference projects. Financing assumptions refer to the cost of interest and other carrying charges, corporate taxes, and depreciation (represented by the FCR in this report), applied to the total CapEx. To capture the financing structure and costs, a fixed charge rate is used for the LCOE equation. Additional details describing FCR are presented in Section 4.5.

The financial structures evaluated for the residential and commercial representative projects assume a host-owned financial structure for residential and commercial host-owned financial structure for the commercial project. Financing assumes debt for approximately $60 \%$ of the

\footnotetext{
${ }^{23}$ Given the scarcity and varying quality of the data, OpEx may vary substantially among projects, and the data included here may not fully represent the challenges that OpEx present to the distributed wind industry.
} 
project costs, consistent with typical debt levels for renewable power as well as conservative lending practices and typical long-term utility-sector debt and equity costs (Lantz et al. 2016).

\subsubsection{Discount Rate}

Typically, various financial terms, such as the cost of debt or equity, are captured in the discount rate, which is in turn used to estimate the cost of energy. For this analysis, the discount rate is calculated as the after-tax WACC and it is presumed that the reported yields for equity are aftertax yields and can be used directly in the WACC calculation. The cost of debt (as a value) is also reported, but because interest on debt is tax deductible, an effective corporate marginal tax rate is used to determine an after-tax cost of debt for the discount rate calculation. The cost of capital gives a basis for WACC assumptions for the representative wind projects and results in a nominal WACC of $5.6 \%$. This WACC was derived assuming a debt fraction of $60 \%$ from Lantz et al. (2016), a nominal debt interest rate of $3.6 \%$, a nominal return on equity of $10 \%$, and a $26 \%$ tax rate. Further details on the blended tax rate are presented in Section 4.5.1. Each actual project, however, has a unique risk profile, financing terms, and ownership structure. For this reason, a single WACC representing the distributed wind installations should be viewed cautiously and used to illustrate general market trends and conditions only.

The inflation rate has been set to $2.5 \%$. This rate aligns with the inflation rate provided in NREL's ATB. Discount rates are initially calculated in nominal after-tax USD, and an estimate of inflation is used to calculate a discount rate in real after-tax USD.

\subsubsection{Economic Evaluation Metrics}

In the economic evaluation of wind energy investments there are two important metrics: the CRF and FCR, with details provided in Section 4.5.2. For the economic evaluation of the residential and commercial projects, analysts assumed the residential host-owned representative project uses a 20-year straight-line depreciation schedule and the commercial/industrial host-owned project uses a 5-year MACRS depreciation schedule.

Table 30 presents the estimated WACC, CRF, and FCR in nominal and real terms using a project design lifetime of 25 years, and a net present value depreciation factor of $57.7 \%$ for the residential project (assuming a 20-year straight-line depreciation schedule) and $86.1 \%$ for the commercial project (assuming a 5-year MACRS depreciation schedule).

Table 30. Summary of Distributed Wind Reference Projects Economic Evaluation Metrics

\begin{tabular}{|lcc|cc|} 
& \multicolumn{2}{c|}{ Residential (20 kW) } & \multicolumn{2}{c|}{ Commercial (100 kW) } \\
& Nominal & Real & Nominal & Real \\
\hline Weighted-average cost of capital (\%) & $5.6 \%$ & $3.03 \%$ & $5.6 \%$ & $3.03 \%$ \\
\hline Capital recovery factor (\%) & $7.53 \%$ & $5.76 \%$ & $7.53 \%$ & $5.76 \%$ \\
\hline Fixed charge rate (\%) & $8.63 \%$ & $6.61 \%$ & $7.89 \%$ & $6.04 \%$ \\
\hline
\end{tabular}

\subsection{Distributed Wind Levelized Cost of Energy}

We calculated the levelized cost of energy for the representative distributed wind projects using the formulation presented in NREL's ATB and the representative turbine technology parameters, site conditions, wind resource, and cost estimates (i.e., CapEx, FCR, OpEx, and AEP). The 
LCOE value for the representative 2019 residential project is estimated at $\$ 159 / \mathrm{MWh}$ and $\$ 104 / \mathrm{MWh}$ for the representative commercial project.

Table 31 and Table 32 summarize the costs for the primary components on a per-kilowatt and per-megawatt-hour basis for the residential and commercial projects, respectively. The graphics in Figure 20 illustrate the LCOE breakdown for the primary LCOE components (i.e., turbine CapEx, BOS CapEx, and O\&M) of the representative residential and commercial wind projects.

Table 31. Summary of Inputs and Reference Project LCOE for 2019 Residential Distributed Wind

\begin{tabular}{|c|c|c|}
\hline & $\begin{array}{c}\text { 20-kW Residential } \\
\text { Wind Turbine } \\
\text { (\$/kW) }\end{array}$ & $\begin{array}{c}\text { 20-kW Residential } \\
\text { Wind Turbine } \\
\text { (\$/MWh) }\end{array}$ \\
\hline Turbine CapEx & 2,575 & 65.9 \\
\hline Balance-of-system CapEx & 3,100 & 79.4 \\
\hline Total CapEx & 5,675 & 145.3 \\
\hline OpEx (\$/kW/yr) & 35 & 13.6 \\
\hline FCR (real) [\%] & \multicolumn{2}{|c|}{$6.6 \%$} \\
\hline Net annual energy production (kWh/kW/yr) & \multicolumn{2}{|c|}{2,580} \\
\hline Net capacity factor (\%) & \multicolumn{2}{|c|}{$29.5 \%$} \\
\hline TOTAL LCOE (\$/MWh) & \multicolumn{2}{|c|}{159} \\
\hline
\end{tabular}

Table 32. Summary of Inputs and Reference Project LCOE for 2019 Commercial Distributed Wind

\begin{tabular}{|l|c|c|}
\hline & $\begin{array}{c}\text { 100-kW Commercial } \\
\text { Wind Turbine } \\
(\$ / k W)\end{array}$ & $\begin{array}{c}100-k W \\
\text { Wind Turbine } \\
\text { (\$/MWh) }\end{array}$ \\
\hline Turbine CapEx & 2,530 & 53.7 \\
\hline Balance-of-system CapEx & 1,770 & 37.5 \\
\hline Total CapEx & $\mathbf{4 , 3 0 0}$ & $\mathbf{9 1 . 2}$ \\
\hline OpEx (\$/kW/yr) & $\mathbf{3 5}$ & $\mathbf{1 2 . 3}$ \\
\hline FCR (real) [\%] & \multicolumn{2}{|c|}{$6.0 \%$} \\
\hline Net annual energy production (kWh/kW/yr) & \multicolumn{2}{|c|}{$32.5 \%$} \\
\hline Net capacity factor (\%) & \multicolumn{2}{|c|}{$\mathbf{1 0 4}$} \\
\hline TOTAL LCOE (\$/MWh) & \multicolumn{2}{|c|}{} \\
\hline
\end{tabular}



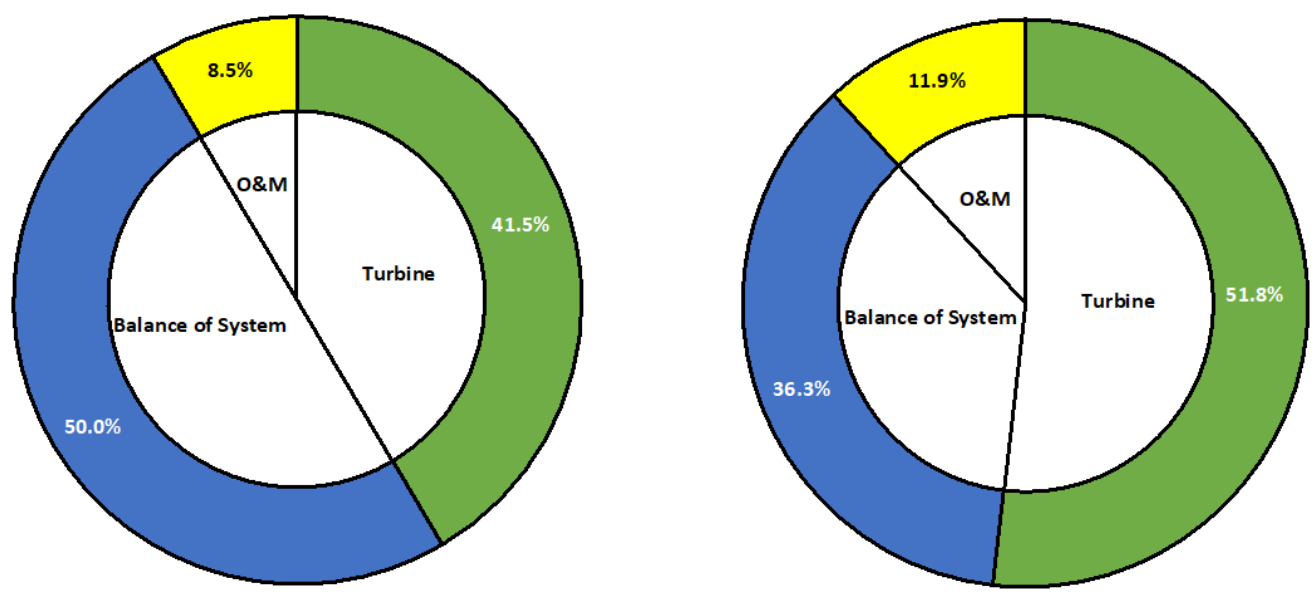

Figure 20. Component-level LCOE contribution for the 2019 residential (left) and commercial (right) distributed wind reference projects operating for 25 years

Note: Empirical data and cost model representation for residential and commercial distributed wind projects are limited; hence, detailed component-level LCOE contributions are not presented in this report.

\subsection{Distributed Wind Levelized Cost of Energy Sensitivities}

The input parameters described earlier reflect the distributed wind reference wind projects; however, input parameters for near-term wind projects are subject to considerable uncertainty. As a result, it is beneficial to investigate how this variability may impact the LCOE. The sensitivity analyses shown in Figure 21 and Figure 22 focus on the basic LCOE inputs: CapEx, $\mathrm{OpEx}$, capacity factor, and FCR, which is broken into its principal elements: discount rate and economic operational lifetime.

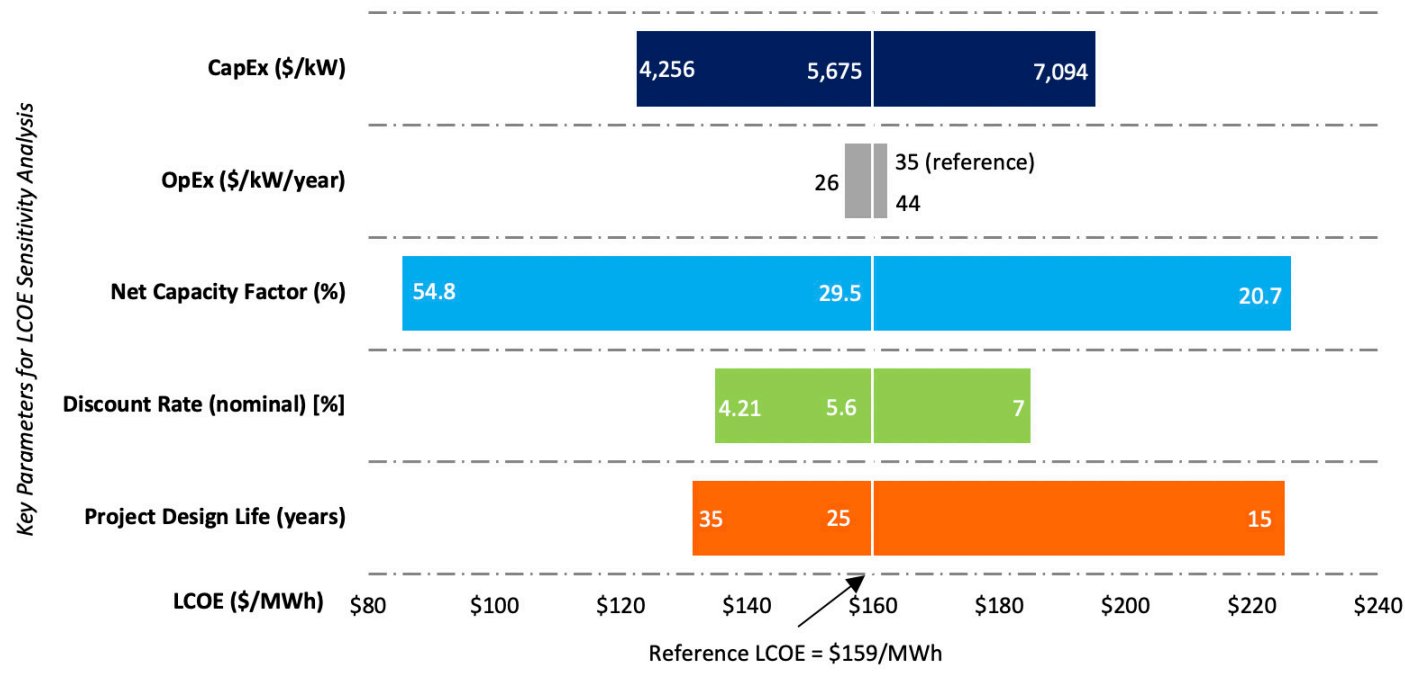

Figure 21. Sensitivity of residential distributed wind LCOE to key input parameters

Note: The reference LCOE reflects a representative industry LCOE. Changes in LCOE for a single variable can be understood by moving to the left or right along a specific variable. Values on the $\mathrm{x}$-axis indicate how the LCOE will change as a given variable is altered and all others are assumed constant (i.e., remain reflective of the reference project). 


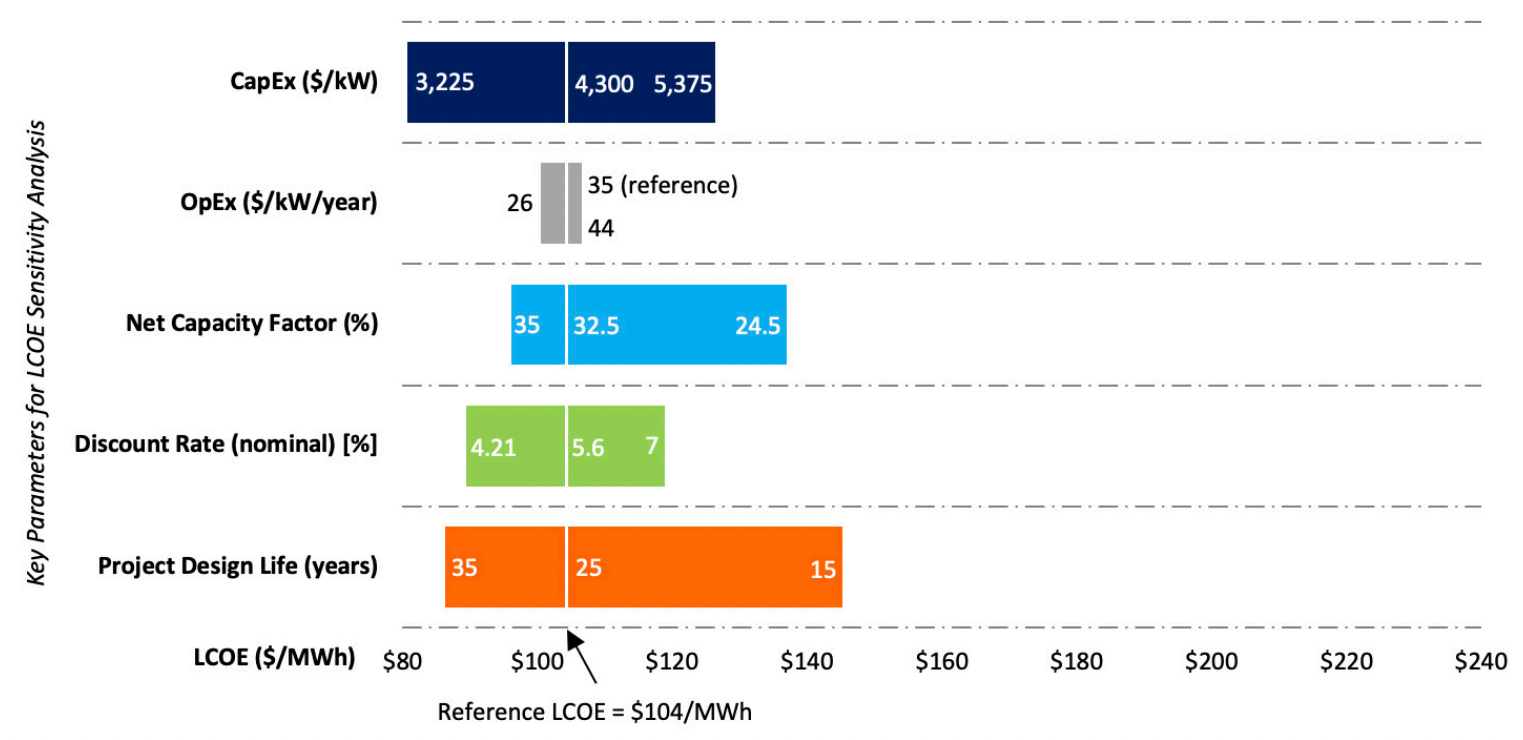

Figure 22. Sensitivity of commercial distributed wind LCOE to key input parameters

Sensitivity analyses are conducted by holding all reference project assumptions constant and altering only the variable in question. As available, sensitivity ranges for all parameters except for project design life are pulled from representative industry data or analysis contained in the "2019 Distributed Wind Data Summary" (Orrell et al. 2020). In cases with insufficient data to assess a sensitivity range, we used values $25 \%$ below and above the baseline value for the calculations. This selection of ranges provides insight into how real-world ranges influence LCOE. The sensitivity analysis yield ranges in LCOE from a low of $\$ 85 / \mathrm{MWh}$ to a high of $\$ 226 / \mathrm{MWh}$ for the residential project and $\$ 81 / \mathrm{MWh}$ to $\$ 145 / \mathrm{MWh}$ for the commercial project. 


\section{Conclusions and Future Work}

This analysis presents a snapshot of the levelized cost of land-based, offshore, and distributed wind energy using empirically derived and modeled data representative of 2019 market conditions. Scenario planning and modeling activities often focus on one number (or cost) for land-based, offshore, and distributed wind LCOE. In reality, the cost of these wind energy technologies varies regionally across the United States and other parts of the world (Table 33 and Table 34).

Notably, the LCOE analysis presented in this report is only one way to measure the cost of wind energy. It does not include other costs and price issues that influence a given wind project's viability, such as transmission, environmental impacts, military constraints, or other areas of consideration (e.g., public policy, consumer costs, energy prices, or public acceptance). In addition, these LCOE estimates do not reflect the value of electricity, incentives, or other policy mechanisms (such as production tax credits or investment tax credits) that affect the sales price of electricity produced from wind projects.

Table 33. Range of LCOE for U.S. Land-Based and Offshore Wind in 2019

\begin{tabular}{|c|c|c|c|c|c|c|}
\hline & \multicolumn{3}{|c|}{ Land-Based Wind } & \multicolumn{3}{|c|}{ Offshore Wind } \\
\hline & Low & Reference & High & Low & Reference & High \\
\hline CapEx $(\$ / k W)$ & 1,160 & 1,436 & 3,000 & 2,570 & 4,077 & 7,080 \\
\hline OpEx (\$/kW/year) & 32 & 43 & 54 & 62 & 124 & 186 \\
\hline Net capacity factor (\%) & $20 \%$ & $43 \%$ & $54 \%$ & $35 \%$ & $49 \%$ & $50 \%$ \\
\hline Discount rate (nominal) [\%] & $5.3 \%$ & $6.3 \%$ & $8.1 \%$ & $3.8 \%$ & $5.3 \%$ & $6.3 \%$ \\
\hline Operational life (years) & 15 & 25 & 35 & 15 & 25 & 35 \\
\hline LCOE (\$/MWh) & 29 & 37 & 78 & 83 & 132 & 174 \\
\hline
\end{tabular}

Table 34. Range of LCOE for Residential and Commercial Distributed Wind in 2019

\begin{tabular}{|lccc|ccc|}
\hline & \multicolumn{3}{c}{ Residential Distributed Wind } & \multicolumn{3}{c|}{ Commercial Distributed Wind } \\
& Low & Reference & High & Low & Reference & High \\
\hline CapEx (\$/kW) & 4,256 & 5,675 & 7,094 & 3,225 & 4,300 & 5,375 \\
\hline OpEx (\$/kW/year) & 26 & 35 & 44 & 26 & 35 & 44 \\
\hline Net capacity factor $(\%)$ & $21 \%$ & $29 \%$ & $55 \%$ & $25 \%$ & $32 \%$ & $35 \%$ \\
\hline Discount rate (nominal) $[\%]$ & $4.2 \%$ & $5.6 \%$ & $7.0 \%$ & $4.2 \%$ & $5.6 \%$ & $7.0 \%$ \\
\hline Operational life (years) & 15 & 25 & 35 & 15 & 25 & 35 \\
\hline LCOE (\$/MWh) & $\mathbf{8 5}$ & $\mathbf{1 5 9}$ & $\mathbf{2 2 6}$ & $\mathbf{8 1}$ & $\mathbf{1 0 4}$ & $\mathbf{1 4 5}$ \\
\hline
\end{tabular}


The analysis and findings in this report helped generate the following conclusions:

- LCOE estimates continue to show a downward trend from the " 2010 Cost of Wind Energy Review" (Tegen et al. 2012) to 2019. Compared to the 2010 report, LCOE has reduced by $56 \%$ for land-based wind and $68 \%$ for fixed-bottom offshore wind. ${ }^{24}$

- We observed the reference project LCOE for land-based installations to be $\$ 37 / \mathrm{MWh}$; the full range of single-variable, land-based sensitivity estimates cover \$29-\$78/MWh.

- The reference offshore LCOE project estimates are $\$ 85 / \mathrm{MWh}$ for fixed-bottom substructures and $\$ 132 / \mathrm{MWh}$ for floating substructures, with a single-variable sensitivity range of $\$ 63-\$ 122 / \mathrm{MWh}$ for fixed bottom and $\$ 83-\$ 174 / \mathrm{MWh}$ for floating. This range is mostly influenced by the large variation in CapEx $(\$ 2,570-\$ 7,080 / \mathrm{kW})$ reported by project developers and is partly a function of differences in water depth and distance to shore.

- The residential distributed wind reference system LCOE was evaluated at $\$ 159 / \mathrm{MWh}$, with a range of values from the single-variable sensitivity analysis of $\$ 85-226 / \mathrm{MWh}$. The commercial distributed wind reference system LCOE was assessed at $\$ 104 / \mathrm{MWh}$, with a range of values from $\$ 81-\$ 145 / \mathrm{MWh}$ from the single-variable sensitivity analysis.

- The range of LCOE calculated for the more than 9,000 GW of theoretical land-based wind capacity ranges from $\$ 29 / \mathrm{MWh}$ to beyond $\$ 200 / \mathrm{MWh}$, with an estimated LCOE range of $\$ 31-\$ 77 / \mathrm{MWh}$ for the projects installed in 2019. For fixed-bottom and floating offshore wind technology, an LCOE range between $\$ 72 / \mathrm{MWh}$ and $\$ 250 / \mathrm{MWh}$ is estimated for approximately $5,430 \mathrm{GW}$ of theoretical capacity for all major U.S. coastal regions (excluding Alaska and Hawaii). The fixed-bottom representative offshore site is on the lower end of this range at $\$ 85 / \mathrm{MWh}$, whereas the floating representative site is near the middle of the range at $\$ 132 / \mathrm{MWh}$.

- The 2020 GPRA target for land-based wind is $\$ 47 / \mathrm{MWh}$ compared to the actual LCOE estimate of \$34/MWh in 2015 USD. ${ }^{25}$ For fixed-bottom offshore wind, the GPRA target for 2019 is $\$ 86 / \mathrm{MWh}$ compared to the actual LCOE estimate of $\$ 83 / \mathrm{MWh}$ in 2018 USD.

NREL continues to strive for a better understanding of costs associated with many components of wind turbines and their related systems. Ongoing collaboration with industry, growing data sets, and enhanced modeling capabilities are expected to continue, leading to better insights and increased awareness of current and future wind power system and component costs. Future updates to this report are anticipated to help maintain a perspective on costs that is grounded in real-time market changes and offer greater insight into the costs and performance of individual components related to the wind electric generation system. In addition, these reports are intended to provide greater clarity regarding wind energy costs and the effects of changes in specific variables on LCOE. The data and tools developed from this work will be used to help inform projections, goals, and improvement opportunities. As the industry evolves and matures, these

\footnotetext{
${ }^{24}$ The LCOE values reported in the "2010 Cost of Wind Energy Review" were inflated from 2010 USD to 2019 USD assuming a $17.2 \%$ cumulative rate of inflation from the Bureau of Labor and Statistics (undated) for comparison.

${ }^{25}$ The 2020 GPRA target and actual levelized cost of energy values for land-based wind are reported in 2015 USD because WETO will report land-based wind values in 2015 USD.
} 
data provide current representative project costs and LCOE estimates for scenario planning, modeling, and goal setting.

Future work entails three primary objectives: 1) continuing to enhance data representing marketbased costs, performance, and technology trends to reflect actual wind industry experience, 2) enhancing the fidelity of bottom-up cost and performance estimation for individual wind power plant components, and 3) understanding sensitivities to factors, such as regional differences, site characteristics, and technology choices. In 2021 and beyond, NREL will continue to work with industry and national laboratory partners to obtain project-specific data to validate and improve models. 


\section{References}

Amendment to Rules Committee Print 116-44. Sec. 127. Credit for Electricity Produced from Certain Renewable Resources. December 2019. https://amendmentsrules.house.gov/amendments/HWC 103 xml1217190022572257.pdf.

Beiter, P., W. Musial, A. Smith, L. Kilcher, R. Damiani, M. Maness, S. Sirnivas, T. Stehly, V. Gevorgian, M. Mooney, G. Scott. 2016. A Spatial-Economic Cost Reduction Pathway Analysis for U.S. Offshore Wind Energy Development from 2015-2030 (Technical Report). Golden, CO: National Renewable Energy Laboratory (NREL). NREL/TP-6A20-66579. https://www.nrel.gov/docs/fy16osti/66579.pdf.

Beiter, P., W. Musial, L. Kilcher, M. Maness, A. Smith. 2017. An Assessment of the Economic Potential of Offshore Wind in the United States from 2015 to 2030 (Technical Report). Golden, CO: National Renewable Energy Laboratory (NREL). NREL/TP-6A20-67675. https://www.nrel.gov/docs/fy17osti/67675.pdf.

Beiter, P., P. Spitsen, W. Musial, E. Lantz. 2019. The Vineyard Wind Power Purchase Agreement: Insights for Estimating Costs of U.S. Offshore Wind Projects (Technical Report). Golden, CO: National Renewable Energy Laboratory (NREL). NREL/TP-5000-72981. https://www.nrel.gov/docs/fy19osti/72981.pdf.

Bolinger, M. 2014. An Analysis of the Costs, Benefits, and Implications of Different Approaches to Capturing the Value of Renewable Energy Tax Incentives. Lawrence Berkeley National Laboratory. https://emp.lbl.gov/sites/default/files/lbnl-6610e.pdf.

Bureau of Labor and Statistics. Undated. "CPI Inflation Calculator.” Accessed September 2017. https://www.bls.gov/data/\#calculators.

Bureau of Ocean Energy Management. 2019. "Lease and Grant Information.” Accessed December 2020. https://www.boem.gov/Lease-and-Grant-Information/.

Chee, Foo Yun. 2018. "Goldman Sachs, Prysmian, others lose challenge against EU cartel fine." Reuters. Accessed July 2, 2019. https://www.reuters.com/article/us-eu-cartelcourt/goldmansachs-prysmian-others-lose-challenge-against-eu-cartel-fine-idUSKBN1K21DY.

Dykes, K., M. Hand, T. Stehly, P. Veers, M. Robinson, E. Lantz. 2017. Enabling the SMART Wind Power Plant of the Future Through Science-Based Innovation (Technical Report). Golden, CO: National Renewable Energy Laboratory (NREL). NREL/TP-5000-68123.

https://www.nrel.gov/docs/fy17osti/68123.pdf.

Eberle, Annika, Owen Roberts, Alicia Key, Parangat Bhaskar, and Katherine Dykes. 2019. NREL's Balance-of-System Cost Model for Land-Based Wind (Technical Report). Golden, CO: National Renewable Energy Laboratory. NREL/TP-6A20-72201. https://www.nrel.gov/docs/fy19osti/72201.pdf. 
Efstathiou, Jim. 2018. "First Big U.S. Offshore Wind Farm Offers \$1.4 Billion to Customers." Bloomberg New Energy Finance, August 1, 2018.

https://www.bloomberg.com/news/articles/2018-08-01/first-big-u-s-offshore-wind-offers-1-4billion-to-customers.

Feldman, D., M. Bolinger, and P. Schwabe. 2020. Current and Future Costs of Renewable Energy Project Finance Across Technologies (Technical Report). Golden, CO: National Renewable Energy Laboratory (NREL). NREL/TP-6A20-76881. https://www.nrel.gov/docs/fy20osti/76881.pdf.

GE Renewable Energy. 2018. "GE announces Haliade-X, the world's most powerful offshore wind turbine." Accessed June 2018. https://www.genewsroom.com/press-releases/ge-announceshaliade-X-worlds-most-powerful-offshore-wind-turbine-284260.

Gilman, P., B. Maurer, L. Feinberg, A. Duerr, L. Peterson, W. Musial, P. Beiter, J. Golladay, J. Stromberg, I. Johnson, D. Boren, A. Moore. 2016. National Offshore Wind Strategy: Facilitating the Development of the Offshore Wind Industry in the United States. DOE/GO-102016-4866. U.S. Department of Energy, Washington, D.C. (US). http://energy.gov/sites/prod/files/2016/09/f33/National-Offshore-Wind-Strategy-report09082016.pdf.

Hundleby, G., K. Freeman, A. Logan, and C. Frost. 2017. Floating Offshore: 55 Technology Innovations That Will Have Greater Impact on Reducing the Cost of Electricity from European Floating Offshore Wind Farms. KiC InnoEnergy and BVG Associates.

http://www.innoenergy.com/new-floating-offshore-wind-report-55-technology-innovations-thatwill-impact-the-lcoe-in-floating-offshore-wind-farms/.

International Electrotechnical Commission. 2020. Accessed September 2020. https://www.iec.ch/.

Lantz, E., B. Sigrin, M. Gleason, R. Preus, I. Baring-Gould. 2016. Assessing the Future of Distributed Wind: Opportunities for Behind-the Meter Projects (Technical Report). Golden, CO: National Renewable Energy Laboratory (NREL). NREL/TP-6A20-

67337. https://www.nrel.gov/docs/fy17osti/67337.pdf.

Maness, M., B. Maples, and A. Smith. 2016. NREL Offshore Balance-of-System Model (Technical Report). Golden, CO: National Renewable Energy Laboratory (NREL). NREL/TP6A20-66874. http://www.nrel.gov/docs/fy17osti/66874.pdf.

Maples, B., G. Saur, M. Hand, R. van de Pietermen, T. Obdam. 2013. Installation, Operation, and Maintenance Strategies to Reduce the Cost of Offshore Wind Energy (Technical Report). Golden, CO: National Renewable Energy Laboratory (NREL). NREL/TP-5000-57403. http://www.nrel.gov/docs/fy13osti/57403.pdf.

MHI Vestas. 2018. "Vineyard Wind Selects MHI Vestas as Preferred Supplier for First LargeScale Offshore Wind Project in the United States." November 27, 2018.

http://www.mhivestasoffshore.com/vineyard-wind-selects-mhi-vestas-as-preferred-supplier. 
Moné, C., A. Smith, B. Maples, and M. Hand. 2015a. 2013 Cost of Wind Energy Review (Technical Report). Golden, CO: National Renewable Energy Laboratory (NREL). NREL/TP5000-63267. http://www.nrel.gov/docs/fy15osti/63267.pdf.

Moné, C., T. Stehly, B. Maples, and E. Settle. 2015b. 2014 Cost of Wind Energy Review (Technical Report). Golden, CO: National Renewable Energy Laboratory (NREL). NREL/TP6A20-64281. http://www.nrel.gov/docs/fy16osti/64281.pdf.

Moné, C., M. Hand, M. Bolinger, J. Rand, D. Heimiller, J. Ho. 2017. 2015 Cost of Wind Energy Review (Technical Report). Golden, CO: National Renewable Energy Laboratory (NREL). NREL/TP-6A20-66861. https://www.nrel.gov/docs/fy17osti/66861.pdf.

Musial, W., P. Beiter, D. Heimiller, and G. Scott. 2016. 2016 Offshore Wind Energy Resource Assessment for the United States (Technical Report). Golden, CO: National Renewable Energy Laboratory (NREL). NREL/TP-5000-66599. http://www.nrel.gov/docs/fy16osti/66599.pdf.

Musial, W., P. Beiter, P. Schwabe, T. Tian, T. Stehly, P. Spitsen. 2017. 2016 Offshore Wind Technologies Market Report. DOE/GO-102017-5031. U.S. Department of Energy, Washington, D.C. (US).

https://energy.gov/sites/prod/files/2017/08/f35/2016\%20Offshore\%20Wind\%20Technologies $\% 2$ 0Market\%20Report.pdf.

Musial, W., P. Beiter, P. Spitsen, J. Nunemaker, V. Gevorgian. 2019. 2018 Offshore Wind Technologies Market Report. DOE/GO-102019-5192. U.S. Department of Energy, Washington, D.C. (US). https://www.energy.gov/eere/wind/downloads/2018-offshore-wind-market-report

Musial, W., P. Beiter, P. Spitsen, J. Nunemaker, V. Gevorgian, A. Cooperman, R. Hammond, M. Shields. 2020. 2019 Offshore Wind Technology Data Update. Golden, CO: National Renewable Energy Laboratory (NREL). NREL/TP-5000-77411.

https://www.nrel.gov/docs/fy21osti/77411.pdf.

National Renewable Energy Laboratory (NREL). (Internal, n.d.). Offshore Wind Database.

NREL. (Internal, n.d.). Land-Based-Wind Balance of System Model.

NREL. (n.d.). “Annual Technology Baseline and Standard Scenarios.” Accessed December 2020. https://atb.nrel.gov/.

NREL. (n.d.). "System Advisor Model (SAM).” Accessed December 2020. https://sam.nrel.gov/.

NREL. (n.d.). "Wind Integration National Dataset Toolkit.” Accessed December 2020. https://www.nrel.gov/grid/wind-toolkit.html.

Orrell, A., D. Preziuso, S. Morris, J. Homer. 2020. 2019 Distributed Wind Data Summary. PNNL-30168. Pacific Northwest National Laboratory, Richland, WA. https://www.pnnl.gov/sites/default/files/media/file/2019\%20Distributed\%20Wind\%20Data\%20S ummary-10Aug20.pdf. 
Pietermen, R., H. Braam, T. Obdam, L. Rademakers, T. van der Zee. 2011. Optimisation of maintenance strategies for offshore wind farms. Energy research Centre of the Netherlands. https://publicaties.ecn.nl/PdfFetch.aspx?nr=ECN-M--11-103.

Shields, M., and J. Nunemaker. 2020. "Process-Based Balance-of-System Cost Modeling for Offshore Wind Power Plants in the United States." Preprint (Conference Paper, NAWEA/WindTech 2019). Golden, CO: National Renewable Energy Laboratory (NREL). NREL/CP-5000-74933. https://www.nrel.gov/docs/fy20osti/74933.pdf.

Short, W., D. J. Packey, and T. Holt. 1995. A Manual for the Economic Evaluation of Energy Efficiency and Renewable Energy Technologies (Technical Report). Golden, CO: National Renewable Energy Laboratory (NREL). NREL/TP-462-5176. http://www.nrel.gov/docs/legosti/old/5173.pdf.

Siemens Gamesa. 2020. "Powered by change: Siemens Gamesa launches 14 MW offshore direct drive turbine with 222-meter rotor." May 19, 2020. https://www.siemensgamesa.com/newsroom/2020/05/200519-siemens-gamesa-turbine-14-222dd.

Spyroudi, A. 2016. Cost Modelling Analysis of Floating Wind Technologies: Assessing the Potential of TLPWIND. Offshore Renewable Energy Catapult.

https://ore.catapult.org.uk/app/uploads/2017/12/SP00006-Cost-Modelling-Analysis-of-FloatingWind-Technologies.pdf.

Stehly, T., D. Heimiller, G. Scott. 2017. 2016 Cost of Wind Energy Review (Technical Report). NREL/TP-6A20-70363. National Renewable Energy Laboratory (NREL), Golden, CO (US). https://www.nrel.gov/docs/fy18osti/70363.pdf.

Stehly, T., P. Beiter, D. Heimiller, G. Scott. 2018. 2017 Cost of Wind Energy Review (Technical Report). NREL/TP-6A20-72167. National Renewable Energy Laboratory (NREL), Golden, CO (US). https://www.nrel.gov/docs/fy18osti/72167.pdf.

Stehly, T., P. Beiter. 2019. 2018 Cost of Wind Energy Review (Technical Report). Golden, CO: National Renewable Energy Laboratory (NREL). NREL/TP-5000-74598. https://www.nrel.gov/docs/fy20osti/74598.pdf.

Tax Cuts and Jobs Act, H.R. 1., $115^{\text {th }}$ Cong. 2017. H.R.1 - An Act to provide for reconciliation pursuant to titles II and V of the concurrent resolution on the budget for fiscal year 2018. https://www.congress.gov/bill/115th-congress/house-bill/1.

Tegen, S., M. Hand, B. Maples, E. Lantz, S. Schwabe, A. Smith. 2012. 2010 Cost of Wind Energy Review (Technical Report). Golden, CO: National Renewable Energy Laboratory (NREL). NREL/TP-5000-52920. http://www.nrel.gov/docs/fy12osti/52920.pdf.

Tegen, S., E. Lantz, M. Hand, B. Maples, A. Smith, P. Schwabe. 2013. 2011 Cost of Wind Energy Review (Technical Report). Golden, CO: National Renewable Energy Laboratory (NREL). NREL/TP-5000-56266. http://www.nrel.gov/docs/fy13osti/56266.pdf. 
UL. Undated. https://aws-dewi.ul.com/software/openwind/.

U.S. Department of Energy (DOE). 2015. Wind Vision: A New Era for Wind Power in the United States. DOE/GO-102015-4557. DOE Office of Energy Efficiency and Renewable Energy. Washington, D.C. (US). http://www.energy.gov/sites/prod/files/WindVision_Report_final.pdf.

Valpy, B. G. Hundleby, K. Freeman, A. Roberts, A. Logan. 2017. Future renewable energy costs: Offshore wind; 57 technology innovations that will have greater impact on reducing the cost of electricity from European offshore wind farms. InnoEnergy and BVG Associates. https://bvgassociates.com/wp-content/uploads/2017/11/InnoEnergy-Offshore-Wind-anticipatedinnovations-impact-2017 A4.pdf.

Wiser, R. and M. Bolinger. 2016. 2015 Wind Technologies Market Report. U.S. Department of Energy, Office of Energy Efficiency and Renewable Energy. Washington, D.C. (US). http://energy.gov/sites/prod/files/2016/08/f33/2015-Wind-Technologies-Market-Report08162016.pdf.

Wiser, R. and M. Bolinger. 2020. Wind Energy Technology Data Update: 2020 Edition. Lawrence Berkeley National Laboratory. https://emp.lbl.gov/wind-technologies-market-report.

Wiser, R., M. Bolinger, and E. Lantz. 2019. "Assessing wind power operating costs in the United States: Results from a survey of wind industry experts." Renewable Energy Focus 30: 46-57. https://www.sciencedirect.com/science/article/pii/S1755008419300092. 


\section{Appendix A. Land-Based Wind Financial Sensitivities}

\section{A1. Thirty-Year Financial Life Sensitivity}

The financial life is the period in which a project achieves the requisite cash flow it needs to recover its initial capital expenditures (CapEx) and meet investors' internal rate of return threshold. In basic levelized cost of energy (LCOE) analysis, this is the period in which capital is recovered at a specified rate of return, with a composite implied internal rate of return threshold based on the project's weighted-average cost of capital. In this report, we derived the 25 -year financial life assumption for the LCOE calculation from the period associated with engineering certification processes and procedures. This appendix includes a calculation of the sensitivity of a longer land-based wind power plant financial life of 30 years and reports its impact on the cost of energy. The consideration of extended financial life is based on data from direct engagements with wind power plant owners. For this sensitivity analysis, the plant's financial life is changed from 25 to 30 years. All other wind power plant assumptions (i.e., CapEx, operational expenditures, and net annual energy production remain the same as the analysis provided in the main body of this report. ${ }^{26} \mathrm{~A}$ summary of the financial parameters impacted by increasing the plant life to 30 years (i.e., capital recovery factor, fixed charge rate, and LCOE) are shown in Table A1.

Table A1. Summary of Land-Based Capital Recovery Factor, Fixed Charge Rate, and Levelized Cost of Energy for a 30-Year Useful Life

\begin{tabular}{|lcc|}
\hline & Nominal & Real \\
\hline Capital recovery factor (\%) & $7.5 \%$ & $5.6 \%$ \\
\hline Fixed charge rate (\%) & $7.9 \%$ & $5.9 \%$ \\
\hline LCOE (\$/megawatt-hour [MWh]) & \multicolumn{3}{|c|}{34} \\
\hline
\end{tabular}

Based on this sensitivity analysis, extending the plant's financial life and assumed period in which the threshold internal rate of return is achieved from 25 to 30 years results in a reduction of LCOE of approximately $6.9 \%$ - a decrease from $\$ 37 / \mathrm{MWh}$ to $\$ 34 / \mathrm{MWh}$.

\section{A2. Financial Sensitivity from the 2018 Cost of Wind Energy Review}

The analysis in this report considers financing assumptions consistent with the 2019 market data (Wiser and Bolinger 2020). Each year, the financial data are updated and may have a dramatic impact on the reported LCOE. For that reason, analysts ran a sensitivity scenario to quantify the impact of LCOE by using the financial assumptions in the "2018 Cost of Wind Energy Review" (Stehly and Beiter 2019). For this sensitivity analysis, the fixed charge rate (FCR; real) is changed from $6.55 \%$ in this year's report to $7.5 \%$ reported last year. All other wind power plant assumptions (i.e., capital expenditures, operational expenditures, and net annual energy production) remain the same as the analysis provided in the main body of this report. A summary of the sensitivity parameters (i.e., capital recovery factor, FCR, and LCOE) are shown in Table A2.

\footnotetext{
26 This sensitivity analysis only considers the extension of the financial life of the wind plant from 25 to 30 years, whereas extension of plant life will impact a project's capital and operational expenditures.
} 
Table A2. Summary of Land-Based Capital Recovery Factor and Levelized Cost of Energy for a $7.5 \%$ FCR

\begin{tabular}{|lcc|}
\hline & Nominal & Real \\
\hline Capital recovery factor (\%) & $9.0 \%$ & $7.1 \%$ \\
\hline Fixed charge rate (\%) & $9.6 \%$ & $7.5 \%$ \\
\hline LCOE (\$MWh) & \multicolumn{2}{|c|}{$\mathbf{4 0}$} \\
\hline
\end{tabular}

Land-based wind LCOE increases from $\$ 37 / \mathrm{MWh}$ to $\$ 40 / \mathrm{MWh}$ - a $10.1 \%$ increase - by assuming the financial assumptions from the "2018 Cost of Wind Energy Review." In this instance, there is a $7 \%$ reduction in LCOE from last year's report from $\$ 43 / \mathrm{MWh}^{27}$ to $\$ 40 / \mathrm{MWh}$ - both in 2019 U.S. dollars - instead of the 12.6\% reduction in LCOE from \$43/MWh to $\$ 37 / \mathrm{MWh}$ in this year's report.

${ }^{27}$ The land-based LCOE value reported in the "2018 Cost of Wind Energy Review" was inflated from 2018 U.S. dollars to 2019 U.S. dollars, assuming a 1.8\% cumulative rate of inflation from the Bureau of Labor and Statistics (undated) for comparison. 


\section{Appendix B. Offshore Wind Financial Sensitivities}

\section{B1. Thirty-Year Financial Life Sensitivity}

The same financial life sensitivity analysis conducted for land-based wind in Appendix A is performed here for fixed-bottom and floating offshore wind. The analysis in this report considers a 25-year financial life derived from the period associated with engineering certification processes and procedures. This appendix includes a calculation of the sensitivity of a longer offshore wind power plant financial life of 30 years for fixed-bottom and floating wind facilities and reports its impact on the cost of energy. The extended financial life assessment is based on data from direct engagements with wind power plant owners and analysis of the European offshore wind power plant lifetime. For this sensitivity analysis, the plant's financial life is changed from 25 to 30 years. All other wind power plant assumptions (i.e., capital expenditures, operational expenditures, and net annual energy production) remain the same as the analysis provided in the main body of this report. ${ }^{28} \mathrm{~A}$ summary of the financial parameters impacted by increasing the plant life to 30 years (i.e., capital recovery factor, fixed charge rate, and levelized cost of energy [LCOE]) are shown in Table B1.

Table B1. Summary of Offshore Capital Recovery Factor, Fixed Charge Rate, and Levelized Cost of Energy for a 30-Year Useful Life

\begin{tabular}{|lcc|cc|} 
& \multicolumn{2}{c}{$\begin{array}{c}\text { North Atlantic } \\
\text { (Fixed Bottom) }\end{array}$} & \multicolumn{2}{c|}{$\begin{array}{c}\text { Pacific Coast } \\
\text { (Floating) }\end{array}$} \\
& Nominal & Real & Nominal & Real \\
\hline Capital recovery factor (\%) & $6.5 \%$ & $4.7 \%$ & $6.5 \%$ & $4.7 \%$ \\
\hline Fixed charge rate (\%) & $6.8 \%$ & $4.9 \%$ & $6.8 \%$ & $4.9 \%$ \\
\hline $\begin{array}{l}\text { TOTAL LCOE (real) } \\
\text { (\$/megawatt-hour [MWh]) }\end{array}$ & \multicolumn{2}{|c|}{$\mathbf{8 2}$} & \multicolumn{2}{|c|}{$\mathbf{1 2 1}$} \\
\hline
\end{tabular}

\section{B2. Financing Sensitivity from 2018 Cost of Wind Energy Review}

The analysis in this report considers financing assumptions consistent with those reported in the 2019 Annual Technology Baseline (Feldman et al. 2020) that are different than those used in the "2018 Cost of Wind Energy Review" (Stehly et al. 2019) This appendix includes a calculation of the sensitivity of the financing assumptions used in that report. For this sensitivity analysis, the fixed charge rate (real) is changed from 5.8\% to 5.6\%. All other wind power plant assumptions (i.e., capital expenditures, operational expenditures, and net annual energy production) remain the same as the analysis provided in the main body of this report. A summary of the sensitivity parameters (i.e., capital recovery factor, fixed charge rate, and levelized cost of energy [LCOE]) are shown in Table B2.

Fixed-bottom projects may experience about an 3\% reduction in LCOE from $\$ 85 / \mathrm{MWh}$ to $\$ 82 / \mathrm{MWh}$. Floating offshore wind projects may experience about a $2 \%$ reduction in LCOE, or a decrease from $\$ 132 / \mathrm{MWh}$ to $\$ 129 / \mathrm{MWh}$ by using the financial assumptions from the "2018 Cost of Wind Energy Review” instead of those presented in this report.

\footnotetext{
28 This sensitivity analysis only considers the extension of the financial life of the wind power plant from 25 to 30 years, whereas extension of plant life will have impacts on a project's capital and operational expenditures.
} 
Table B2. Summary of Offshore Capital Recovery Factor, Fixed Charge Rate, and Levelized Cost of Energy Using the 2018 Cost of Wind Energy Review Assumptions (25-year Life)

\begin{tabular}{|lcc|cc|} 
& \multicolumn{2}{c}{$\begin{array}{c}\text { North Atlantic } \\
\text { (Fixed Bottom) }\end{array}$} & \multicolumn{2}{c|}{$\begin{array}{c}\text { Pacific Coast } \\
\text { (Floating) }\end{array}$} \\
& Nominal & Real & Nominal & Real \\
\hline $\begin{array}{l}\text { Weighted-average cost of } \\
\text { capital (\%) }\end{array}$ & $5.0 \%$ & $2.4 \%$ & $5.0 \%$ & $2.4 \%$ \\
\hline Capital recovery factor (\%) & $7.1 \%$ & $5.4 \%$ & $7.1 \%$ & $5.4 \%$ \\
\hline Fixed charge rate (\%) & $7.4 \%$ & $5.6 \%$ & $7.4 \%$ & $5.6 \%$ \\
\hline $\begin{array}{l}\text { TOTAL LCOE (real) } \\
\text { (\$/MWh) }\end{array}$ & \multicolumn{2}{|c|}{$\mathbf{8 2}$} & \multicolumn{3}{|c|}{$\mathbf{1 2 9}$} \\
\hline
\end{tabular}




\section{Appendix C. Offshore Wind Reference Site Development}

In this report, we define reference sites for fixed-bottom and floating offshore wind technology. These reference sites are intended to reflect site conditions that represent near- to medium-term U.S. project development and based on a replicable methodology.

We conducted the following steps to identify a reference site for fixed-bottom and floating offshore wind technology, respectively:

1. For each offshore wind region (as specified in Gilman et al. 2016), a 600-megawatt (MW) cohesive area within each Bureau of Ocean Energy Management lease and Call Area delineation (Bureau of Ocean Energy Management 2019) that is closest to shore (measured by direct distance) was identified, while:

- Only considering lease area(s) if at least one is available within an offshore wind region

- Consider Call Area(s) if there is no designated lease area

- Assuming a turbine spacing of $3 \mathrm{MW} /$ square kilometer (Musial et al. 2016).

2. Define "reference site" parameters by averaging key spatial parameters across the areas defined in step \#1 for each offshore wind region:

- Water depth

○ Wind speed

○ Gross and net capacity factor

- Array efficiency

- Distance from site to cable landfall

- Distance from cable landfall to onshore substation

- Distance from site to construction port

○ Distance from site to operation and maintenance port

○ Wave height.

3. Designated the "North Atlantic" offshore wind region to be the reference site for fixed bottom and the "Pacific Coast" to represent floating offshore wind technology. This determination was made because these regions experience the highest commercial activity for these technology types (Musial et al. 2019).

4. Specify the spatial parameters from step \#2 in the Offshore Wind Cost Model to determine the levelized cost of energy.

Results for the spatial parameters calculated for each regional reference sites are shown in Table C1. 
Table C1. Spatial Parameters for Regional Reference Sites

\begin{tabular}{|c|c|c|c|c|c|c|c|c|c|c|}
\hline & Depth & $\begin{array}{c}\text { Wind } \\
\text { Speed }\end{array}$ & $\begin{array}{c}\text { GCF } \\
\mathbf{6} \\
\mathbf{M W}\end{array}$ & $\mathbf{N C F}$ & $\begin{array}{c}\text { Array } \\
\text { Efficiency }\end{array}$ & $\begin{array}{c}\text { Site to } \\
\text { Cable } \\
\text { Landfall }\end{array}$ & $\begin{array}{c}\text { Distance } \\
\text { Cable } \\
\text { Landfall to } \\
\text { Substation }\end{array}$ & $\begin{array}{c}\text { Site to } \\
\text { CP }\end{array}$ & $\begin{array}{c}\text { Site to } \\
\text { OP }\end{array}$ & $\begin{array}{c}\text { Average } \\
\text { HS }\end{array}$ \\
\hline Units & $m$ & $m / s$ & $\%$ & $\%$ & $\%$ & $k m$ & $k m$ & $k m$ & $k m$ & $m$ \\
\hline $\begin{array}{c}\text { North } \\
\text { Atlantic }\end{array}$ & 34 & 9.03 & $58 \%$ & $48 \%$ & $92 \%$ & 50 & 9 & 116 & 114 & 1.2 \\
\hline $\begin{array}{c}\text { South } \\
\text { Atlantic }\end{array}$ & 30 & 8.58 & $53 \%$ & $44 \%$ & $92 \%$ & 51 & 7 & 118 & 118 & 1.2 \\
\hline $\begin{array}{c}\text { Pacific } \\
\text { Coast }\end{array}$ & 739 & 8.22 & $48 \%$ & $38 \%$ & $93 \%$ & 36 & 8 & 189 & 189 & 2.4 \\
\hline Hawaii & 764 & 8.59 & $52 \%$ & $43 \%$ & $94 \%$ & 18 & 10 & 36 & 36 & 1.6 \\
\hline
\end{tabular}

Note: The "North Atlantic" serves as fixed bottom and the "Pacific Coast" serves as the floating offshore wind technology reference site. The "South Atlantic" and "Hawaii" are included for reference only.

Acronyms in Table C1:

$\mathrm{CP}$ : construction port

GCF: gross capacity factor

HS: significant annual average wave height

km: kilometer(s)

$\mathrm{m}:$ meter(s)

$\mathrm{m} / \mathrm{s}$ : meters per second

NCF: net capacity factor

OP: operations port 


\section{Appendix D. Offshore Wind Cost Model Updates}

The National Renewable Energy Laboratory's Offshore Wind Cost Model, also referred to as the Offshore Regional Cost Analyzer, is subject to continuous data updates and validation, which help ensure that the model reflects the latest industry and market developments. The following key revisions to the model were implemented since the release of last year's annual cost report:

- Several cost elements, including finance terms like total capital expenditures (CapEx) and operational expenditures, turbine CapEx, and lease area price were validated through a detailed analysis of the power purchase agreement between Vineyard Wind LLC and Massachusetts electric distribution companies (Beiter et al. 2019). The agreement price for the first commercial-scale U.S. offshore wind project suggests that the cost premium for the "new" U.S. market is less pronounced than anticipated by many analysts.

- Turbine CapEx was reduced from previous estimates of about $\$ 1,600 /$ kilowatt to $\$ 1,300 /$ kilowatt in 2018 (informed by Efstathiou [2018] and Hundleby et al. [2017]).

- Export system cable costs in 2019 were reduced by $25 \%$ compared to Beiter et al. (2016) to account for recent cost reductions resulting from low-cost material use (i.e., higher aluminum content), lower commodity prices, and cost reductions resulting from an antitrust case against an international cable cartel (Chee 2018).

- A lease price of $\$ 50$ million, which roughly corresponds to the price paid by Equinor for its New York lease area in 2016 (Musial et al. 2019), was included in the Offshore Wind Cost Model. ${ }^{29}$

- A new cost reduction trajectory from 2018 through 2032 was derived from an expert elicitation conducted by Valpy et al. (2017) and Hundleby et al. (2017).

- Floating substructure and array cable costs were updated through industry consultation.

\footnotetext{
${ }^{29}$ Note that in its latest auction, the Bureau of Ocean Energy Management awarded three offshore wind lease areas off Massachusetts in December 2018 at a lease sale price record of \$135 million each; more than tripling the previous record of $\$ 42$ million paid for the New York lease area sale in 2016 (Musial et al. 2019).
} 


\section{Appendix E. Summary of Assumptions for 2019 Reference Projects}

A summary of the capital expenditures, technology characteristics, annual energy production, operation and maintenance expenditures, and finance assumptions for each of the reference projects presented in this report are provided in Appendix E. The information is provided in separate tables for land-based-wind (Table E1), fixed-bottom offshore wind (Table E2), floating offshore wind (Table E3), residential distributed wind (Table E4), and commercial distributed wind reference projects.

Table E1. Land-Based-Wind Reference Project Levelized Cost of Energy Assumptions

\begin{tabular}{|c|c|c|c|}
\hline Assumption & Units & Value & Notes \\
\hline \multicolumn{4}{|c|}{ Wind Power Plant Characteristics } \\
\hline Wind plant capacity & $\begin{array}{l}\text { megawatt(s) } \\
(\mathrm{MW})\end{array}$ & 200 & \multirow{2}{*}{ Representative of commercial-scale projects } \\
\hline Number of turbines & & 79 & \\
\hline Turbine rating & MW & 2.55 & \multirow{3}{*}{$\begin{array}{l}\text { "2020 Wind Energy Technology Data Update" (Wiser and } \\
\text { Bolinger 2020) }\end{array}$} \\
\hline Rotor diameter & $\begin{array}{l}\text { meter(s) } \\
(\mathrm{m})\end{array}$ & 121.2 & \\
\hline Hub height & $\mathrm{m}$ & 90.1 & \\
\hline Specific power & watts $/ \mathrm{m}^{2}$ & 221 & Calculation \\
\hline Cut-in wind speed & $\mathrm{m} / \mathrm{s}$ & 3 & \multirow{2}{*}{ Typical turbine characteristics } \\
\hline Cut-out wind speed & $\mathrm{m} / \mathrm{s}$ & 25 & \\
\hline $\begin{array}{l}\text { Annual average wind } \\
\text { speed at } 50 \mathrm{~m}\end{array}$ & $\mathrm{~m} / \mathrm{s}$ & 7.25 & Reference site wind speed \\
\hline $\begin{array}{l}\text { Annual average wind } \\
\text { speed at hub height }\end{array}$ & $\mathrm{m} / \mathrm{s}$ & 7.89 & $\begin{array}{l}\text { Between International Electrotechnical Class (IEC) class } \\
\text { III }(7.5 \mathrm{~m} / \mathrm{s}) \text { and IEC class II }(8.5 \mathrm{~m} / \mathrm{s})\end{array}$ \\
\hline Weibull k factor & & 2.0 & \\
\hline Shear exponent & & 0.143 & Shear for neutral stability conditions \\
\hline $\begin{array}{l}\text { Altitude above mean sea } \\
\text { level }\end{array}$ & $\mathrm{m}$ & 450 & Altitude at turbine foundation \\
\hline Losses & $\%$ & $15 \%$ & \multirow{2}{*}{ "Wind Vision": (U.S. Department of Energy 2015) } \\
\hline Availability & $\%$ & $98 \%$ & \\
\hline Net energy capture & $\begin{array}{c}\text { Megawatt- } \\
\text { hour/ } \\
\text { MW/yr }\end{array}$ & 3,734 & \multirow[t]{2}{*}{ System Advisor Model calculation } \\
\hline Net capacity factor & $\%$ & $42.6 \%$ & \\
\hline \multicolumn{4}{|c|}{ Capital Expenditures (CapEx) } \\
\hline Total CapEx & $\begin{array}{c}\begin{array}{l}\text { \$/kilowatt } \\
(\mathrm{kW})\end{array} \\
\end{array}$ & 1,436 & $\begin{array}{l}\text { "2020 Wind Energy Technology Data Update" (Wiser and } \\
\text { Bolinger 2020) }\end{array}$ \\
\hline Turbine & $\$ / \mathrm{kW}$ & 991 & \multirow{6}{*}{2015 Cost and Scaling Model } \\
\hline Rotor module & $\$ / \mathrm{kW}$ & 287 & \\
\hline Blades & $\$ / \mathrm{kW}$ & 184 & \\
\hline Pitch assembly & $\$ / \mathrm{kW}$ & 60 & \\
\hline Hub assembly & $\$ / \mathrm{kW}$ & 44 & \\
\hline Nacelle module & $\$ / \mathrm{kW}$ & 488 & \\
\hline
\end{tabular}




\begin{tabular}{|c|c|c|c|}
\hline Assumption & Units & Value & Notes \\
\hline $\begin{array}{c}\text { Nacelle structural } \\
\text { assembly }\end{array}$ & $\$ / \mathrm{kW}$ & 98 & \\
\hline Drivetrain assembly & $\$ / \mathrm{kW}$ & 192 & \\
\hline $\begin{array}{c}\text { Nacelle electrical } \\
\text { assembly }\end{array}$ & $\$ / \mathrm{kW}$ & 167 & \\
\hline Yaw assembly & $\$ / \mathrm{kW}$ & 32 & \\
\hline Tower module & $\$ / \mathrm{kW}$ & 215 & \\
\hline Balance of system & $\$ / \mathrm{kW}$ & 326 & \multirow{7}{*}{$\begin{array}{l}\text { Land-based Balance-of-System Model (National } \\
\text { Renewable Energy Laboratory [NREL]; model description } \\
\text { provided in Section 3) }\end{array}$} \\
\hline Development cost & $\$ / \mathrm{kW}$ & 16 & \\
\hline Engineering management & $\$ / \mathrm{kW}$ & 18 & \\
\hline Foundation & $\$ / \mathrm{kW}$ & 59 & \\
\hline Site access and staging & $\$ / \mathrm{kW}$ & 44 & \\
\hline Assembly and installation & $\$ / \mathrm{kW}$ & 44 & \\
\hline Electrical infrastructure & $\$ / \mathrm{kW}$ & 145 & \\
\hline Soft costs & $\$ / \mathrm{kW}$ & 120 & \\
\hline Construction finance & $\$ / \mathrm{kW}$ & 34 & Project construction over 3 years \\
\hline Contingency & $\$ / k W$ & 86 & $6 \%$ of total CapEx \\
\hline \multicolumn{4}{|c|}{ Operational Expenditures (OpEx) } \\
\hline Total OpEx & $\$ / \mathrm{kW} /$ year & 43 & (Wiser et al. 2019) \\
\hline \multicolumn{4}{|c|}{ Financials } \\
\hline Project design life & Years & 25 & $\begin{array}{l}\text { Project life for Government Performance and Reporting } \\
\text { Act (GPRA) reporting }\end{array}$ \\
\hline $\begin{array}{l}\text { Tax rate (combined state } \\
\text { and federal) }\end{array}$ & $\%$ & $26 \%$ & \multirow{4}{*}{2020 Annual Technology Baseline (ATB; atb.nrel.gov) } \\
\hline Inflation rate & $\%$ & $2.5 \%$ & \\
\hline $\begin{array}{l}\text { Interest during } \\
\text { construction (nominal) }\end{array}$ & $\%$ & $4.0 \%$ & \\
\hline $\begin{array}{l}\text { Construction finance } \\
\text { factor }\end{array}$ & $\%$ & $102 \%$ & \\
\hline Debt fraction & $\%$ & $50 \%$ & \multirow{3}{*}{$\begin{array}{l}\text { "2020 Wind Energy Technology Data Update" (Wiser and } \\
\text { Bolinger 2020) }\end{array}$} \\
\hline $\begin{array}{l}\text { Debt interest rate } \\
\text { (nominal) }\end{array}$ & $\%$ & $3.6 \%$ & \\
\hline $\begin{array}{l}\text { Return on equity } \\
\text { (nominal) }\end{array}$ & $\%$ & $10 \%$ & \\
\hline $\begin{array}{l}\text { WACC* (nominal; after } \\
\text { tax) }\end{array}$ & $\%$ & $6.3 \%$ & \multirow{4}{*}{ Calculation } \\
\hline WACC (real; after tax) & $\%$ & $3.7 \%$ & \\
\hline $\begin{array}{l}\text { Capital recovery factor } \\
\text { (nominal; after tax) }\end{array}$ & $\%$ & $8.1 \%$ & \\
\hline $\begin{array}{l}\text { Capital recovery factor } \\
\text { (real; after tax) }\end{array}$ & $\%$ & $6.2 \%$ & \\
\hline Depreciable basis & $\%$ & $100 \%$ & Simplified depreciation schedule \\
\hline Depreciation schedule & $\begin{array}{c}\text { 5-year } \\
\text { MACRS** }\end{array}$ & $\begin{array}{c}\text { 5-year } \\
\text { MACRS }\end{array}$ & Standard for U.S. wind projects \\
\hline $\begin{array}{l}\text { Depreciation adjustment } \\
\text { (net present value [NPV]) }\end{array}$ & $\%$ & $85 \%$ & \multirow[t]{2}{*}{ Calculation } \\
\hline Project finance factor & $\%$ & $105 \%$ & \\
\hline
\end{tabular}




\begin{tabular}{|l|c|c|c|}
\hline \multicolumn{1}{|c|}{ Assumption } & Units & Notes \\
\cline { 1 - 2 } $\begin{array}{l}\text { Fixed charge rate (FCR) } \\
\text { (nominal) }\end{array}$ & $\%$ & $8.5 \%$ & \\
\hline FCR (real) & $\%$ & $6.5 \%$ & \\
\cline { 1 - 3 } Levelized cost of energy & $\$ / \mathrm{MWh}$ & $37 \quad$ Calculation \\
\hline
\end{tabular}

*Weighted-average cost of capital (WACC)

**Modified Accelerated Cost Recovery System (MACRS)

Table E2. Fixed-Bottom Offshore Wind Reference Project Levelized Cost of Energy Assumptions

\begin{tabular}{|c|c|c|c|}
\hline Assumption & Units & Value & Notes \\
\hline \multicolumn{4}{|c|}{ Wind Power Plant Characteristics } \\
\hline Wind plant capacity & MW & 600 & Representative of commercial-scale projects \\
\hline Number of turbines & number & 100 & \multirow{4}{*}{$\begin{array}{l}\text { Calculation } \\
\text { NREL analysis of globally installed offshore wind } \\
\text { turbines }\end{array}$} \\
\hline Turbine rating & MW & 6.06 & \\
\hline Rotor diameter & $\mathrm{m}$ & 151 & \\
\hline Hub height & $\mathrm{m}$ & 101.8 & \\
\hline Specific power & $\mathrm{W} / \mathrm{m}^{2}$ & 340 & \multirow[t]{5}{*}{ Calculation } \\
\hline Water depth & $\mathrm{m}$ & 34 & \\
\hline Substructure type & & Monopile & \\
\hline Distance from shore & $\mathrm{km}$ & 50 & \\
\hline Cut-in wind speed & $\mathrm{m} / \mathrm{s}$ & 3 & \\
\hline Cut-out wind speed & $\mathrm{m} / \mathrm{s}$ & 25 & \multirow{5}{*}{ Baseline site for Cost of Energy Review } \\
\hline $\begin{array}{l}\text { Average annual wind speed at } 50 \\
\mathrm{~m}\end{array}$ & $\mathrm{~m} / \mathrm{s}$ & 8.4 & \\
\hline $\begin{array}{l}\text { Average annual wind speed at } \\
\text { hub height }\end{array}$ & $\mathrm{m} / \mathrm{s}$ & 9.12 & \\
\hline Shear exponent & & 0.10 & \\
\hline Weibull k & & 2.1 & \\
\hline Total system losses & $\%$ & $16.0 \%$ & $\begin{array}{l}\text { Offshore Regional Cost Analyzer (ORCA) (based } \\
\text { on Beiter et al. 2016) BVG reductions applied }\end{array}$ \\
\hline Gross energy capture & $\begin{array}{c}\mathrm{MWh} / \mathrm{MW} \\
/ \mathrm{yr}\end{array}$ & 5,081 & Calculation \\
\hline Net energy capture & $\begin{array}{c}\mathrm{MWh} / \mathrm{MW} \\
/ \mathrm{yr}\end{array}$ & 4,270 & \\
\hline Gross capacity factor & $\%$ & $58.0 \%$ & \multirow{2}{*}{ ORCA (based on Beiter et al. 2016) } \\
\hline Net capacity factor & $\%$ & $48.75 \%$ & \\
\hline \multicolumn{4}{|c|}{ CapEx } \\
\hline Total CapEx & $\$ / \mathrm{kW}$ & 4,077 & \multirow{5}{*}{ ORCA (based on Beiter et al. 2016) } \\
\hline Turbine & $\$ / \mathrm{kW}$ & 1,301 & \\
\hline Rotor nacelle assembly & $\$ / \mathrm{kW}$ & 1,119 & \\
\hline Tower & $\$ / \mathrm{kW}$ & 182 & \\
\hline Balance of system & $\$ / \mathrm{kW}$ & 2,131 & \\
\hline
\end{tabular}




\begin{tabular}{|c|c|c|c|}
\hline Assumption & Units & Value & Notes \\
\hline Development & $\$ / \mathrm{kW}$ & 138 & \\
\hline Project management & $\$ / \mathrm{kW}$ & 70 & \\
\hline Substructure and foundation & $\$ / \mathrm{kW}$ & 817 & \\
\hline Substructure & $\$ / \mathrm{kW}$ & 379 & \\
\hline Foundation & $\$ / \mathrm{kW}$ & 439 & \\
\hline $\begin{array}{l}\text { Port and staging, logistics, } \\
\text { and transportation }\end{array}$ & $\$ / \mathrm{kW}$ & 58 & \\
\hline Electrical infrastructure & $\$ / \mathrm{kW}$ & 761 & \\
\hline Array cable system & $\$ / \mathrm{kW}$ & 96 & \\
\hline Export cable system & $\$ / \mathrm{kW}$ & 498 & \\
\hline Grid connection & $\$ / \mathrm{kW}$ & 167 & \\
\hline Assembly and installation & $\$ / \mathrm{kW}$ & 198 & \\
\hline Turbine installation & $\$ / \mathrm{kW}$ & 71 & \\
\hline $\begin{array}{l}\text { Substructure and } \\
\text { foundation installation }\end{array}$ & $\$ / \mathrm{kW}$ & 128 & \\
\hline Soft costs & $\$ / k W$ & 645 & \\
\hline Insurance during construction & $\$ / \mathrm{kW}$ & 44 & \\
\hline Decommissioning bond & $\$ / \mathrm{kW}$ & 58 & \\
\hline Construction finance & $\$ / \mathrm{kW}$ & 183 & \\
\hline Sponsor contingency & $\$ / k W$ & 316 & \\
\hline Procurement contingency & $\$ / \mathrm{kW}$ & 199 & \\
\hline Installation contingency & $\$ / \mathrm{kW}$ & 117 & \\
\hline $\begin{array}{l}\text { Project completions/ } \\
\text { commissioning }\end{array}$ & $\$ / \mathrm{kW}$ & 44 & \\
\hline \multicolumn{4}{|c|}{ OpEx } \\
\hline Total OpEx & $\$ / \mathrm{kW} / \mathrm{yr}$ & 124 & \multirow{3}{*}{$\begin{array}{l}\text { ORCA (based on Beiter et al. 2016) BVG } \\
\text { reductions applied }\end{array}$} \\
\hline Operations (pretax) & $\$ / \mathrm{kW} / \mathrm{yr}$ & 29 & \\
\hline Maintenance & $\$ / \mathrm{kW} / \mathrm{yr}$ & 99 & \\
\hline \multicolumn{4}{|c|}{ Financials } \\
\hline Project design life & years & 25 & Offshore wind project life for GPRA reporting \\
\hline $\begin{array}{l}\text { Tax rate (combined state and } \\
\text { federal) }\end{array}$ & $\%$ & $26 \%$ & \multirow{5}{*}{ ATB (2020) } \\
\hline Inflation rate & $\%$ & $2.5 \%$ & \\
\hline Debt fraction & $\%$ & $67 \%$ & \\
\hline Debt interest rate (nominal) & $\%$ & $4.0 \%$ & \\
\hline Return on equity (nominal) & $\%$ & $10.0 \%$ & \\
\hline WACC (nominal; after tax) & $\%$ & $5.29 \%$ & \multirow{4}{*}{ Calculation } \\
\hline WACC (real; after tax) & $\%$ & $2.72 \%$ & \\
\hline $\begin{array}{l}\text { Capital recovery factor (nominal; } \\
\text { after tax) }\end{array}$ & $\%$ & $7.3 \%$ & \\
\hline $\begin{array}{l}\text { Capital recovery factor (real; after } \\
\text { tax) }\end{array}$ & $\%$ & $5.6 \%$ & \\
\hline Depreciable basis & $\%$ & $100 \%$ & Simplified depreciation schedule \\
\hline
\end{tabular}




\begin{tabular}{|c|c|c|c|}
\hline Assumption & Units & Value & Notes \\
\hline Depreciation schedule & & $\begin{array}{c}\text { 5-year } \\
\text { MACRS }\end{array}$ & Standard for U.S. wind projects \\
\hline Depreciation adjustment (NPV) & $\%$ & $87 \%$ & \multirow{4}{*}{ Calculation } \\
\hline Project finance factor & $\%$ & $105 \%$ & \\
\hline FCR (nominal) & $\%$ & $7.64 \%$ & \\
\hline FCR (real) & $\%$ & $5.82 \%$ & \\
\hline Levelized cost of energy & \$/MWh & 85 & Calculation \\
\hline
\end{tabular}

Table E3. Floating Offshore Wind Reference Project LCOE Assumptions

\begin{tabular}{|c|c|c|c|}
\hline Assumption & Units & Value & Notes \\
\hline \multicolumn{4}{|c|}{ Wind Power Plant Characteristics } \\
\hline Wind plant capacity & MW & 600 & Representative of commercial-scale projects \\
\hline Number of turbines & number & 100 & Calculation \\
\hline Turbine rating & MW & 6.06 & \multirow{3}{*}{$\begin{array}{l}\text { NREL analysis of globally installed offshore wind } \\
\text { turbines }\end{array}$} \\
\hline Rotor diameter & $\mathrm{m}$ & 151 & \\
\hline Hub height & $\mathrm{m}$ & 101.8 & \\
\hline Specific power & $\mathrm{W} / \mathrm{m} 2$ & 340 & Calculation \\
\hline Water depth & $\mathrm{m}$ & 739 & \multirow{9}{*}{ Baseline site for Cost of Energy Review } \\
\hline Substructure type & & $\begin{array}{c}\text { Semi- } \\
\text { submersible }\end{array}$ & \\
\hline Distance from shore & $\mathrm{km}$ & 36 & \\
\hline Cut-in wind speed & $\mathrm{m} / \mathrm{s}$ & 3 & \\
\hline Cut-out wind speed & $\mathrm{m} / \mathrm{s}$ & 25 & \\
\hline $\begin{array}{l}\text { Average annual } \\
\text { wind speed at } 50 \mathrm{~m}\end{array}$ & $\mathrm{~m} / \mathrm{s}$ & 7.7 & \\
\hline $\begin{array}{l}\text { Average annual } \\
\text { wind speed at hub } \\
\text { height }\end{array}$ & $\mathrm{m} / \mathrm{s}$ & 8.3 & \\
\hline Shear exponent & & 0.10 & \\
\hline Weibull k & & 2.1 & \\
\hline Total system losses & $\%$ & $20.9 \%$ & ORCA (based on Beiter et al. 2016) \\
\hline $\begin{array}{l}\text { Gross energy } \\
\text { capture }\end{array}$ & $\begin{array}{l}\text { MWh/M } \\
\text { W/yr }\end{array}$ & 4,205 & Calculation \\
\hline Net energy capture & $\begin{array}{l}\text { MWh/M } \\
\text { W/yr }\end{array}$ & 3,328 & \\
\hline $\begin{array}{l}\text { Gross capacity } \\
\text { factor }\end{array}$ & $\%$ & $48.0 \%$ & \multirow[t]{2}{*}{ ORCA (based on Beiter et al. 2016) } \\
\hline Net capacity factor & $\%$ & $38.0 \%$ & \\
\hline \multicolumn{4}{|c|}{ CapEx } \\
\hline Total CapEx & $\$ / \mathrm{kW}$ & 5,328 & \\
\hline Turbine & $\$ / \mathrm{kW}$ & 1,301 & \\
\hline
\end{tabular}




\begin{tabular}{|c|c|c|c|}
\hline Assumption & Units & Value & Notes \\
\hline $\begin{array}{c}\text { Rotor nacelle } \\
\text { assembly }\end{array}$ & $\$ / \mathrm{kW}$ & 1,119 & \multirow{24}{*}{$\begin{array}{l}\text { ORCA (based on Beiter et al. 2016) BVG reductions } \\
\text { applied (except to turbine to be consistent with fixed } \\
\text { bottom }\end{array}$} \\
\hline Tower & $\$ / \mathrm{kW}$ & 182 & \\
\hline $\begin{array}{l}\text { Balance of } \\
\text { system }\end{array}$ & $\$ / \mathrm{kW}$ & 3,237 & \\
\hline Development & $\$ / \mathrm{kW}$ & 165 & \\
\hline $\begin{array}{c}\text { Project } \\
\text { management }\end{array}$ & $\$ / \mathrm{kW}$ & 85 & \\
\hline $\begin{array}{c}\text { Substructure and } \\
\text { foundation }\end{array}$ & $\$ / \mathrm{kW}$ & 1,438 & \\
\hline Substructure & $\$ / \mathrm{kW}$ & 1,135 & \\
\hline Foundation & $\$ / \mathrm{kW}$ & 303 & \\
\hline $\begin{array}{l}\text { Port and } \\
\text { staging, } \\
\text { logistics, and } \\
\text { transportation }\end{array}$ & $\$ / \mathrm{kW}$ & 44 & \\
\hline $\begin{array}{c}\text { Electrical } \\
\text { infrastructure }\end{array}$ & $\$ / k W$ & 979 & \\
\hline Array cable system & $\$ / \mathrm{kW}$ & 391 & \\
\hline Export cable system & $\$ / \mathrm{kW}$ & 468 & \\
\hline Grid connection & $\$ / \mathrm{kW}$ & 120 & \\
\hline $\begin{array}{c}\text { Assembly and } \\
\text { installation }\end{array}$ & $\$ / \mathrm{kW}$ & 439 & \\
\hline Turbine installation & $\$ / \mathrm{kW}$ & 317 & \\
\hline $\begin{array}{l}\text { Substructure } \\
\text { and foundation } \\
\text { installation }\end{array}$ & $\$ / \mathrm{kW}$ & 121 & \\
\hline Soft costs & $\$ / \mathrm{kW}$ & 790 & \\
\hline $\begin{array}{l}\text { Insurance during } \\
\text { construction }\end{array}$ & $\$ / \mathrm{kW}$ & 52 & \\
\hline $\begin{array}{c}\text { Decommissioning } \\
\text { bond }\end{array}$ & $\$ / \mathrm{kW}$ & 76 & \\
\hline $\begin{array}{l}\text { Construction } \\
\text { finance }\end{array}$ & $\$ / \mathrm{kW}$ & 221 & \\
\hline $\begin{array}{c}\text { Sponsor } \\
\text { contingency }\end{array}$ & $\$ / \mathrm{kW}$ & 389 & \\
\hline $\begin{array}{l}\text { Procurement } \\
\text { contingency }\end{array}$ & $\$ / \mathrm{kW}$ & 237 & \\
\hline $\begin{array}{l}\text { Installation } \\
\text { contingency }\end{array}$ & $\$ / \mathrm{kW}$ & 152 & \\
\hline $\begin{array}{c}\text { Project completions/ } \\
\text { commissioning }\end{array}$ & $\$ / \mathrm{kW}$ & 52 & \\
\hline \multicolumn{4}{|c|}{ OpEx } \\
\hline Total OpEx & $\$ / \mathrm{kW} / \mathrm{yr}$ & 130 & \multirow{3}{*}{$\begin{array}{l}\text { ORCA (based on Beiter et al. 2016) BVG reductions } \\
\text { applied }\end{array}$} \\
\hline $\begin{array}{l}\text { Operations } \\
\text { (pretax) }\end{array}$ & $\$ / \mathrm{kW} / \mathrm{yr}$ & 28 & \\
\hline Maintenance & $\$ / k W / y r$ & 102 & \\
\hline
\end{tabular}




\begin{tabular}{|c|c|c|c|}
\hline Assumption & Units & Value & Notes \\
\hline Project design life & years & 25 & Offshore wind project life for GPRA reporting \\
\hline $\begin{array}{l}\text { Tax rate (combined } \\
\text { state and federal) }\end{array}$ & $\%$ & $26 \%$ & \multirow{7}{*}{ 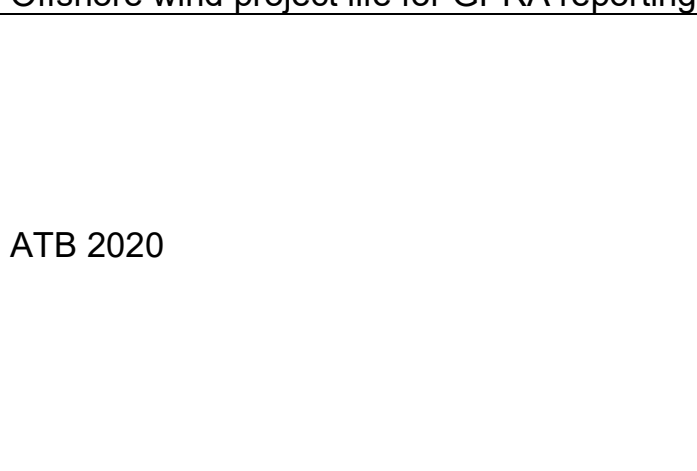 } \\
\hline Federal & $\%$ & $21 \%$ & \\
\hline State & $\%$ & $7.5 \%$ & \\
\hline Inflation rate & $\%$ & $2.5 \%$ & \\
\hline Debt fraction & $\%$ & $67 \%$ & \\
\hline $\begin{array}{l}\text { Debt interest rate } \\
\text { (nominal) }\end{array}$ & $\%$ & $4.0 \%$ & \\
\hline $\begin{array}{l}\text { Return on equity } \\
\text { (nominal) }\end{array}$ & $\%$ & $10.0 \%$ & \\
\hline $\begin{array}{l}\text { WACC (nominal; } \\
\text { after tax) }\end{array}$ & $\%$ & $5.29 \%$ & \multirow{4}{*}{ Calculation } \\
\hline $\begin{array}{l}\text { WACC (real; after } \\
\text { tax) }\end{array}$ & $\%$ & $2.72 \%$ & \\
\hline $\begin{array}{l}\text { Capital recovery } \\
\text { factor (nominal; after } \\
\text { tax) }\end{array}$ & $\%$ & $7.3 \%$ & \\
\hline $\begin{array}{l}\text { Capital recovery } \\
\text { factor (real; after } \\
\text { tax) }\end{array}$ & $\%$ & $5.6 \%$ & \\
\hline Depreciable basis & $\%$ & $100 \%$ & Simplified depreciation schedule \\
\hline $\begin{array}{l}\text { Depreciation } \\
\text { schedule }\end{array}$ & & $\begin{array}{c}\text { 5-year } \\
\text { MACRS }\end{array}$ & Standard for U.S. wind projects \\
\hline $\begin{array}{l}\text { Depreciation } \\
\text { adjustment (NPV) }\end{array}$ & $\%$ & $87 \%$ & \multirow{4}{*}{ Calculation } \\
\hline $\begin{array}{l}\text { Project finance } \\
\text { factor }\end{array}$ & $\%$ & $105 \%$ & \\
\hline FCR (nominal) & $\%$ & $7.6 \%$ & \\
\hline FCR (real) & $\%$ & $5.82 \%$ & \\
\hline $\begin{array}{l}\text { Levelized cost of } \\
\text { energy }\end{array}$ & $\$ / M W h$ & 132 & Calculation \\
\hline
\end{tabular}

Table E4. Residential Distributed Wind Reference Project LCOE Assumptions

\begin{tabular}{|c|c|c|c|}
\hline Assumption & Units & Value & Notes \\
\hline \multicolumn{4}{|c|}{ Wind Power Plant Characteristics } \\
\hline Wind plant capacity & $\mathrm{kW}$ & 20 & \multirow{2}{*}{ Representative of residential distributed wind project } \\
\hline Number of turbines & & 1 & \\
\hline Turbine rating & $\mathrm{kW}$ & 20 & \multirow{3}{*}{$\begin{array}{l}\text { "Assessing the Future of Distributed Wind: } \\
\text { Opportunities for Behind-the Meter Projects." (Lantz et } \\
\text { al. 2016) }\end{array}$} \\
\hline Rotor diameter & $\mathrm{m}$ & 12.4 & \\
\hline Hub height & $\mathrm{m}$ & 30 & \\
\hline Specific power & $\mathrm{W} / \mathrm{m} 2$ & 166 & Calculation \\
\hline Cut-in wind speed & $\mathrm{m} / \mathrm{s}$ & 3 & \multirow{2}{*}{ Typical turbine characteristics } \\
\hline Cut-out wind speed & $\mathrm{m} / \mathrm{s}$ & 20 & \\
\hline
\end{tabular}




\begin{tabular}{|c|c|c|c|}
\hline Assumption & Units & Value & Notes \\
\hline $\begin{array}{l}\text { Annual average } \\
\text { wind speed at } 50 \mathrm{~m}\end{array}$ & $\mathrm{~m} / \mathrm{s}$ & 6.00 & Reference site wind speed \\
\hline $\begin{array}{l}\text { Annual average } \\
\text { wind speed at hub } \\
\text { height }\end{array}$ & $\mathrm{m} / \mathrm{s}$ & 5.58 & IEC class IV \\
\hline Weibull k factor & & 2.0 & \\
\hline Shear exponent & & 0.143 & Shear for neutral stability conditions \\
\hline $\begin{array}{l}\text { Altitude above } \\
\text { mean sea level }\end{array}$ & $\mathrm{m}$ & 0 & Altitude at turbine foundation \\
\hline Losses & $\%$ & $7 \%$ & \multirow{2}{*}{$\begin{array}{l}\text { Informed by "Competitiveness Improvement Project" } \\
\text { (https://www.nrel.gov/wind/competitiveness- } \\
\text { improvement-project.html) }\end{array}$} \\
\hline Availability & $\%$ & $95 \%$ & \\
\hline Net energy capture & $\begin{array}{c}\mathrm{kWh} / \mathrm{kW} / \\
\mathrm{yr}\end{array}$ & 2,580 & \multirow{2}{*}{$\begin{array}{l}\text { Calculation in Openwind (UL website (undated): } \\
\text { https://aws-dewi.ul.com/software/openwind/) }\end{array}$} \\
\hline Net capacity factor & $\%$ & $29.5 \%$ & \\
\hline \multicolumn{4}{|r|}{ CapEx } \\
\hline Total CapEx & $\$ / \mathrm{kW}$ & 5,675 & \\
\hline Turbine & $\$ / \mathrm{kW}$ & 2,575 & $\begin{array}{l}\text { "2019 Distributed Wind Data Summary" (Orrell et al. } \\
\text { 2020) }\end{array}$ \\
\hline Balance of system & $\$ / \mathrm{kW}$ & 3,100 & $\begin{array}{l}\text { "NREL's Balance-of-System Cost Model for Land- } \\
\text { Based Wind" (Eberle et al. 2019) }\end{array}$ \\
\hline \multicolumn{4}{|r|}{ OpEx } \\
\hline Total OpEx & $\$ / \mathrm{kW} /$ year & 35 & $\begin{array}{l}\text { "Assessing the Future of Distributed Wind: } \\
\text { Opportunities for Behind-the Meter Projects" (Lantz et } \\
\text { al. 2016) }\end{array}$ \\
\hline \multicolumn{4}{|c|}{ Financials } \\
\hline Project design life & Years & 25 & $\begin{array}{l}\text { Project life for Government Performance and } \\
\text { Reporting Act (GPRA) reporting }\end{array}$ \\
\hline $\begin{array}{l}\text { Tax rate (combined } \\
\text { state and federal) }\end{array}$ & $\%$ & $26 \%$ & \multirow[t]{2}{*}{2020 Annual Technology Baseline (atb.nrel.gov) } \\
\hline Inflation rate & $\%$ & $2.5 \%$ & \\
\hline Debt fraction & $\%$ & $60 \%$ & $\begin{array}{l}\text { "Assessing the Future of Distributed Wind: } \\
\text { Opportunities for Behind-the Meter Projects" (Lantz et } \\
\text { al. 2016) }\end{array}$ \\
\hline $\begin{array}{l}\text { Debt interest rate } \\
\text { (nominal) }\end{array}$ & $\%$ & $3.6 \%$ & \multirow{2}{*}{2020 Annual Technology Baseline (atb.nrel.gov) } \\
\hline $\begin{array}{l}\text { Return on equity } \\
\text { (nominal) }\end{array}$ & $\%$ & $10 \%$ & \\
\hline $\begin{array}{l}\text { WACC (nominal; } \\
\text { after tax) }\end{array}$ & $\%$ & $5.6 \%$ & \multirow{4}{*}{ Calculation } \\
\hline $\begin{array}{l}\text { WACC (real; after } \\
\text { tax) }\end{array}$ & $\%$ & $3.0 \%$ & \\
\hline $\begin{array}{l}\text { Capital recovery } \\
\text { factor (nominal; } \\
\text { after tax) }\end{array}$ & $\%$ & $7.5 \%$ & \\
\hline $\begin{array}{l}\text { Capital recovery } \\
\text { factor (real; after } \\
\text { tax) }\end{array}$ & $\%$ & $5.8 \%$ & \\
\hline Depreciable basis & $\%$ & $100 \%$ & Simplified depreciation schedule \\
\hline
\end{tabular}




\begin{tabular}{|c|c|c|c|}
\hline Assumption & Units & Value & Notes \\
\hline $\begin{array}{l}\text { Depreciation } \\
\text { schedule }\end{array}$ & $\begin{array}{l}20 \text {-year } \\
\text { straight } \\
\text { line }\end{array}$ & $\begin{array}{c}20 \text {-year } \\
\text { straight } \\
\text { line }\end{array}$ & \\
\hline $\begin{array}{l}\text { Depreciation } \\
\text { adjustment (NPV) }\end{array}$ & $\%$ & $58 \%$ & \multirow{4}{*}{ Calculation } \\
\hline $\begin{array}{l}\text { Project finance } \\
\text { factor }\end{array}$ & $\%$ & $115 \%$ & \\
\hline FCR (nominal) & $\%$ & $8.6 \%$ & \\
\hline FCR (real) & $\%$ & $6.6 \%$ & \\
\hline $\begin{array}{l}\text { Levelized cost of } \\
\text { energy }\end{array}$ & $\$ / M W h$ & 159 & Calculation \\
\hline
\end{tabular}

Table E5. Commercial Distributed Wind Reference Project LCOE Assumptions

\begin{tabular}{|c|c|c|c|}
\hline Assumption & Units & Value & Notes \\
\hline \multicolumn{4}{|c|}{ Wind Power Plant Characteristics } \\
\hline Wind plant capacity & $\mathrm{kW}$ & 100 & \multirow{2}{*}{ Representative of residential distributed wind project } \\
\hline Number of turbines & & 1 & \\
\hline Turbine rating & $\mathrm{kW}$ & 100 & \multirow{3}{*}{$\begin{array}{l}\text { "Assessing the Future of Distributed Wind: } \\
\text { Opportunities for Behind-the Meter Projects" (Lantz et } \\
\text { al. 2016) }\end{array}$} \\
\hline Rotor diameter & $\mathrm{m}$ & 27.6 & \\
\hline Hub height & $\mathrm{m}$ & 40 & \\
\hline Specific power & $\mathrm{W} / \mathrm{m}^{2}$ & 167 & Calculation \\
\hline Cut-in wind speed & $\mathrm{m} / \mathrm{s}$ & 3 & \multirow{2}{*}{ Typical turbine characteristics } \\
\hline Cut-out wind speed & $\mathrm{m} / \mathrm{s}$ & 25 & \\
\hline $\begin{array}{l}\text { Annual average } \\
\text { wind speed at } 50 \mathrm{~m}\end{array}$ & $\mathrm{~m} / \mathrm{s}$ & 6.00 & Reference site wind speed \\
\hline $\begin{array}{l}\text { Annual average } \\
\text { wind speed at hub } \\
\text { height }\end{array}$ & $\mathrm{m} / \mathrm{s}$ & 5.81 & IEC class IV \\
\hline Weibull k factor & & 2.0 & \\
\hline Shear exponent & & 0.143 & Shear for neutral stability conditions \\
\hline $\begin{array}{l}\text { Altitude above mean } \\
\text { sea level }\end{array}$ & $\mathrm{m}$ & 0 & Altitude at turbine foundation \\
\hline Losses & $\%$ & $7 \%$ & \multirow{2}{*}{$\begin{array}{l}\text { Informed by "Competitiveness Improvement Project" } \\
\text { (https://www.nrel.gov/wind/competitiveness- } \\
\text { improvement-project.html) }\end{array}$} \\
\hline Availability & $\%$ & $95 \%$ & \\
\hline Net energy capture & $\begin{array}{c}\mathrm{kWh} / \mathrm{kW} / \\
\mathrm{yr}\end{array}$ & 2,846 & \multirow{2}{*}{$\begin{array}{l}\text { Calculation in Openwind (UL website (undated): } \\
\text { https://aws-dewi.ul.com/software/openwind/) }\end{array}$} \\
\hline Net capacity factor & $\%$ & $32.5 \%$ & \\
\hline \multicolumn{4}{|r|}{$\overline{\text { CapEx }}$} \\
\hline Total CapEx & $\$ / \mathrm{kW}$ & 4,300 & \\
\hline Turbine & $\$ / \mathrm{kW}$ & 2,530 & $\begin{array}{l}\text { "2019 Distributed Wind Data Summary" (Orrell et al. } \\
2020 \text { ) }\end{array}$ \\
\hline Balance of system & $\$ / \mathrm{kW}$ & 1,770 & $\begin{array}{l}\text { "NREL's Balance-of-System Cost Model for Land- } \\
\text { Based Wind" (Eberle et al. 2019) }\end{array}$ \\
\hline
\end{tabular}




\begin{tabular}{|c|c|c|c|}
\hline Assumption & Units & Value & Notes \\
\hline \multicolumn{4}{|r|}{ OpEx } \\
\hline Total OpEx & $\$ / \mathrm{kW} /$ year & 35 & $\begin{array}{l}\text { "Assessing the Future of Distributed Wind: } \\
\text { Opportunities for Behind-the Meter Projects" (Lantz et } \\
\text { al. 2016) }\end{array}$ \\
\hline \multicolumn{4}{|r|}{ Financials } \\
\hline Project design life & Years & 25 & $\begin{array}{l}\text { Project life for Government Performance and Reporting } \\
\text { Act (GPRA) reporting }\end{array}$ \\
\hline $\begin{array}{l}\text { Tax Rate (combined } \\
\text { state and federal) }\end{array}$ & $\%$ & $26 \%$ & \multirow{2}{*}{2020 Annual Technology Baseline (page: atb.nrel.gov) } \\
\hline Inflation rate & $\%$ & $2.5 \%$ & \\
\hline Debt fraction & $\%$ & $60 \%$ & $\begin{array}{l}\text { "Assessing the Future of Distributed Wind: } \\
\text { Opportunities for Behind-the Meter Projects" (Lantz et } \\
\text { al. 2016) }\end{array}$ \\
\hline $\begin{array}{l}\text { Debt interest rate } \\
\text { (nominal) }\end{array}$ & $\%$ & $3.6 \%$ & \multirow{2}{*}{2020 Annual Technology Baseline (atb.nrel.gov) } \\
\hline $\begin{array}{l}\text { Return on equity } \\
\text { (nominal) }\end{array}$ & $\%$ & $10 \%$ & \\
\hline $\begin{array}{l}\text { WACC (nominal; } \\
\text { after tax) }\end{array}$ & $\%$ & $5.6 \%$ & \multirow{4}{*}{ Calculation } \\
\hline $\begin{array}{l}\text { WACC (real; after } \\
\text { tax) }\end{array}$ & $\%$ & $3.0 \%$ & \\
\hline $\begin{array}{l}\text { Capital recovery } \\
\text { factor (nominal; } \\
\text { after tax) }\end{array}$ & $\%$ & $7.5 \%$ & \\
\hline $\begin{array}{l}\text { Capital recovery } \\
\text { factor (real; after } \\
\text { tax) }\end{array}$ & $\%$ & $5.8 \%$ & \\
\hline Depreciable basis & $\%$ & $100 \%$ & Simplified depreciation schedule \\
\hline $\begin{array}{l}\text { Depreciation } \\
\text { schedule }\end{array}$ & $\begin{array}{l}5 \text { year } \\
\text { MACRS }\end{array}$ & $\begin{array}{l}5 \text { year } \\
\text { MACRS }\end{array}$ & \\
\hline $\begin{array}{l}\text { Depreciation } \\
\text { adjustment (NPV) }\end{array}$ & $\%$ & $86 \%$ & \multirow{4}{*}{ Calculation } \\
\hline $\begin{array}{l}\text { Project finance } \\
\text { factor }\end{array}$ & $\%$ & $105 \%$ & \\
\hline FCR (nominal) & $\%$ & $7.9 \%$ & \\
\hline FCR (real) & $\%$ & $6.0 \%$ & \\
\hline $\begin{array}{l}\text { Levelized cost of } \\
\text { energy }\end{array}$ & $\$ / M W h$ & 104 & Calculation \\
\hline
\end{tabular}

